\title{
O SIGNIFICADO DA PRÁTICA PROFISSIONAL E DO ENSINO \\ EM UNIDADE BÁSICA DE SAÚDE: UM ESTUDO DE CULTURA ORGANIZACIONAL NO CENTRO DE SAÚDE-ESCOLA \\ BARRA FUNDA.
}

\section{CÁSSIO SILVEIRA}

\begin{abstract}
Tese de Doutorado apresentada ao Departamento de Prática de Saúde Pública da Faculdade de Saúde Pública da Universidade de São Paulo para obtenção do Grau de Doutor em Saúde Pública.
\end{abstract}

Área de concentração: Serviços de Saúde

Orientadora: Professora Doutora Aracy W. de P. Spinola.

São Paulo 
Autorizo, exclusivamente para fins acadêmicos e científicos, a reprodução total ou parcial desta tese, por processos fotocopiadores. Assinatura:

Data:

$38 \times 5 / 99$ doe 
Dedico meu trabalho à Meri,

Ana Laura, Myrses e

Vicente ( in memoriam). 


\section{AGRADECIMENTOS}

Os agradecimentos são muitos e sinceros.

Começo pela professora Dra. Aracy W. de P. Spinola, orientadora e grande incentivadora de minha carreira como professor. Meu muito obrigado pela orientação e pelas oportunidades do exercício das atividades de ensino desenvolvidas através de palestras na Faculdade de Saúde Pública da Universidade de São Paulo durante o curso de pós-graduação.

Da Faculdade de Saúde Pública agradeço ainda à professora Dra. Evelyn $N$. de $C$. Sá pela atenção e comentários realizados que muito contribuíram para meu desenvolvimento; à professora Maria da Penha Vasconcelos que contribuiu para as primeiras definições do projeto de pesquisa; à professora Dra. Maria Cecilia P. Focesi pelas oportunidades do exercicio da atividade docente em Metodologia Científica e de Pesquisa; e, finalmente, às minhas colegas na disciplina de Fundamentos da Investigação Cientifica: Carla, Helena, Sônia, Telma, e Tomires, pela paciência que tiveram em ouvir e comentar o projeto desta pesquisa.

Agradecimentos ao $\mathrm{CNPq}$ e Capes, instituições de fomento à pesquisa, pela concessão das bolsas de auxilio à pesquisa.

Da Universidade Federal de São Paulo-E.P.M., agradeço ao Professor Dr. Laércio Joel Franco (chefe de departamento de Medicina Preventiva) e ao Professor Francisco R. Gonçalves Santos (chefe da disciplina de Epidemiologia) pelo apoio prestado o que possibilitou a execução da pesquisa; à professora Dra. Paulete Goldenberg pelo apoio oferecido; à secretária Aída G. de Araújo pelo apoio oferecido e a paciência em resolver minhas solicitações.

À professora Dr. Regina C. De Rosa Stella, Vice-reitora da Universidade Federal de São Paulo-E.P.M., pela atenção, incentivo e seus ensinamentos de professora e pesquisadora a mim transmitidos quando do desenvolvimento dos trabalhos de avaliação de ensino naquela universidade. 
À professora Dra. Mara Helena de Andréa Gomes do departamento de Medicina Preventiva da Unifesp-E.P.M. pelo acompanhamento, incentivo, cobertura nos momentos em que mais precisei e, fundamentalmente, por ter me ensinado mais um sentido a ser atribuído ao trabalho de professor: nunca tornar as idéias rigidas e fixas em nosso pensamento; problematizá-las e discuti-las é criar as condições para o diálogo.

À Dra. Simone Schenkman, colega e amiga, pelas oportunidades a mim oferecidas em poder compartilhar de seu apoio em vários momentos do trabalho, com a alegria e a sinceridade sempre presentes em seu espírito.

Do Centro de Saúde-Escola Barra Funda, meus agradecimentos ao Dr. Nivaldo Carneiro Jr. pela permissão concedida para a realização do trabalho e, também, pela infinita paciência em ler e reler as várias versões do projeto e do relatório final. Agradeço pelo privilégio a mim concedido da amizade que acabamos por firmar. À dra. Marta Campagnone Andrade e aos demais funcionários e agora amigos do CS-Escola Barra Funda pelo apoio e contribuições oferecidas ao trabalho.

Agradecimentos sinceros também à Professora Dra. Regina Marsiglia, ao Professor Dr. Nelson Ibañez e ao Professor Otávio Mercadante pelo apoio e incentivo oferecidos. Estes professores foram gentis e pacientes com quem queria trabalhar uma história que Ihes pertence. Espero ter conseguido dar um retorno mínimo às expectativas criadas durante 0 desenvolvimento do trabalho.

Meus agradecimentos aos familiares que acompanharam e suportaram minha trajetória em busca do aprimoramento. Agradeço a meu irmão Vicente pela constante troca de experiências que pudemos realizar sobre nossas inserções nos programas de pós-graduação e, também, pela ajuda na composição do resumo em língua inglesa. À Regina Sirullo pelo trabalhos de transcrição e digitação desenvolvidos.

Agradecimentos especiais à muito querida Marina S. De Sordi. Cuidou e cuida de mim, de minha filha e de minha esposa. Espero que à sua contribuição eu esteja retribuindo com o carinho e a dedicação merecidos. À 
Rosângela e ao Afonso, amigos, pela constante preocupação demonstrada durante meu processo de aprimoramento, meus agradecimentos.

Finalmente, à minha esposa Meri pela dedicação e companheirismo a partir dos quais pude seguir meus trabalhos sempre sendo incentivado e valorizado no percurso de meu desenvolvimento intelectual. Ensinou-me, muitas vezes sem saber, que o trabalho deve significar uma das grandes emoções de nossas existências. 


\section{RESUMO}

Silveira, C. O significado da prática profissional e do ensino em unidade básica de saúde: um estudo de cultura organizacional no Centro de Saúde-Escola Barra Funda. São Paulo; 1998 [Tese de Doutorado - Faculdade de Saúde Pública da USP].

Estudo de cultura organizacional realizado no Centro de SaúdeEscola Barra Funda abrangendo os aspectos históricos de sua formação e trajetória, as concepçōes de funcionários e professores envolvidos nos trabalhos de assistência, ensino e pesquisa, com o objetivo de compreender o significado da organização para os que nela atuam servindo a população que habita, transita ou trabalha na área de abrangência da unidade de saúde.

O estudo propiciou uma compreensão da unidade sob a perspectiva das mudanças ocorridas no perfil da clientela assistida e as transformações que foram sendo desenvolvidas para acompanhar a dinâmica social. Ao serem incorporados ao serviço segmentos sociais até então não assistidos de forma sistemática - moradores de rua e profissionais do sexo, por exemplo, pode-se inferir que as transformações internas à organização não ocorrem pela imposição dessa dinâmica exterior à mesma, mas pela existência de concepções e práticas que justificam a afirmação de um serviço público voltado para a compreensão dessa dinâmica social e as possiveis soluções que podem ser viabilizadas. Neste sentido, concluiu-se que a atuação da unidade está respaldada na promoção e proteção à saúde da população orientadas por uma sensibilidade com relação às questões sociais. 


\section{SUMMARY}

Silveira, C. O Significado da prática profissional e do ensino em unidade básica de saúde: um estudo de cultura organizacional no Centro de Saúde-Escola Barra Funda [The meaning of the professional practice and teaching in a basic unit of health: a study of organizational culture in Centro de Saúde]. São Paulo (BR); 1998 [Tese de doutorado Faculdade de Saúde Pública da Universidade de São Paulo].

A study of organizational culture accomplished in the Centro de Saúde-Escola Barra Funda in which were taken both in consideration the historical aspects of its formation and trajectory, and the employees and teachers conceptions involved in the works of assistance, teaching and research, objectifying to understand the meaning of the organization for the ones that act serving the population that inhabit, work or transit in the area of the health unit

The study propitiated an understanding of the unit under the perspective of the changes happened in the profile of attended clientele and the necessary transformations that were being developed to accompany the social dynamics. The incorporation of social segments to the service which were not attended before in a systematic way - street inhabitants and prostitutes, for example - an inference was done that the organization internal transformations didn't happen for the imposition of that external dynamics, but for the existence of conceptions and practices that justify the statement of a public service turned to the understanding of that social dynamics and the possible feasible solutions. In this sense, the conclusion is that the performance of the unit is concerned with the promotion and protection of the population health guided by a sensibility in relation to the social issues. 


\section{ÍNDICE}

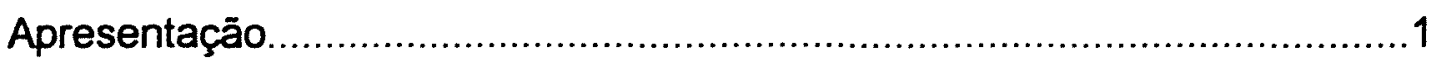

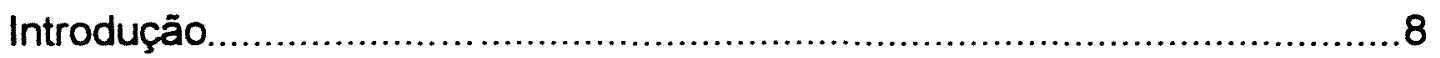

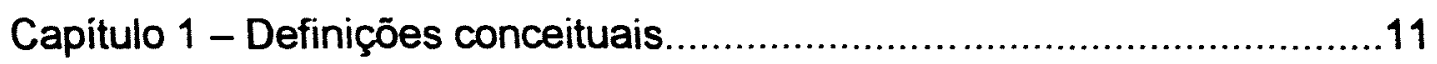

A abordagem antropológica e o conceito de cultura organizacional..........21

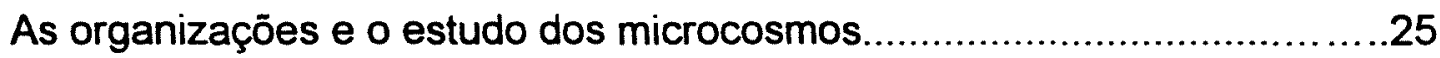

Desdobramentos do conceito de cultura organizacional...........................33

A cultura: relações simbólicas, relações sociais ......................................38

A construção do conceito de cultura organizacional...............................41

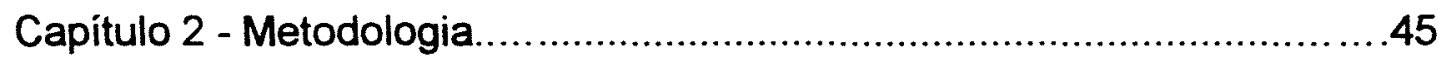

Limites e possibilidades de um estudo qualitativo....................................50

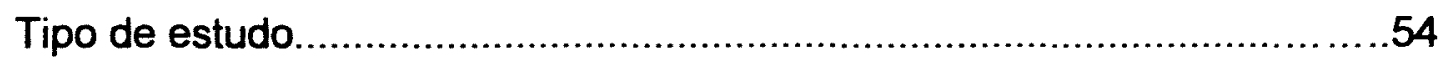

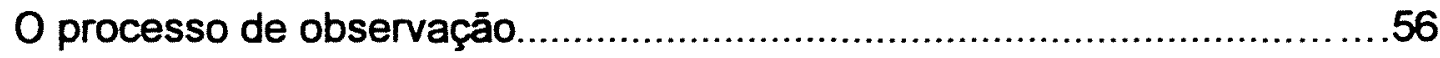

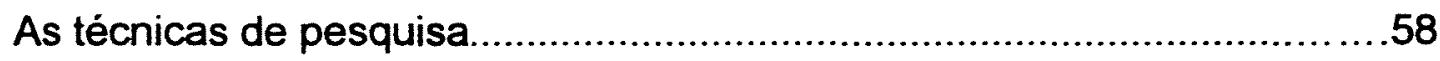

Desenvolvimento e organização do campo de pesquisa.............................63

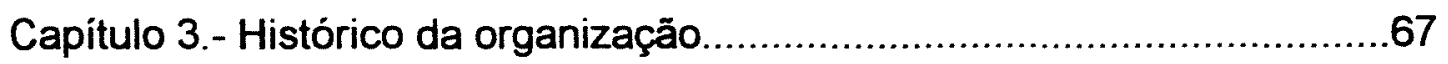

A formação do Centro de Saúde Experimental da Barra Funda.................70

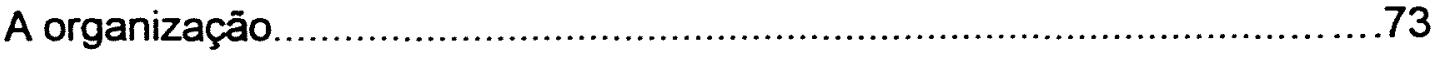

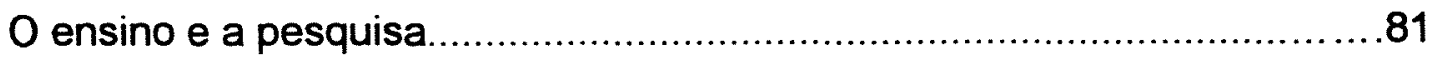

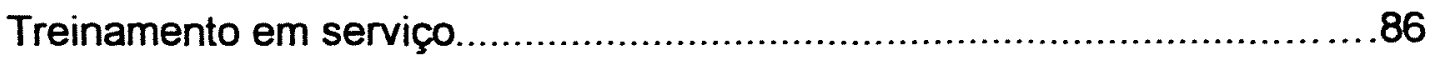

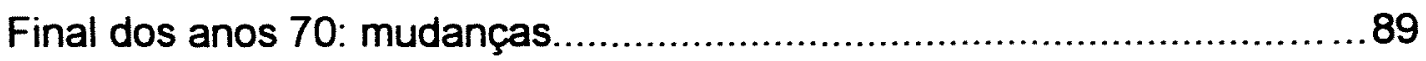

O Centro de Saúde-Escola Barra Funda na atualidade............................95

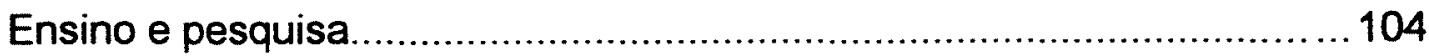


4.1 - As auxiliares. 109

Setor administrativo: porta de entrada da unidade.. 109

As auxiliares, antigas visitadoras. 110

4.2 - As enfermeiras. 125

Concepçōes sobre saúde e organização de serviços. 126 Inserções administrativas. 129

Observação da área de atuação. 132

$\mathrm{O}$ ensino e a pesquisa. 137

4.3 - As assistentes sociais. 141

4.4 - Os médicos. 148

Considerações finais 162

Referências bibliográficas. 169

Anexos 


\section{APRESENTAÇÃO}

A temática desenvolvida neste trabalho de pesquisa percorreu basicamente dois caminhos convergentes: por um lado, contribuiu a minha formação em Ciências Sociais, momento em que já cultivava interesses pela área de saúde e, posteriormente, o mestrado também em Ciências Sociais, cuja temática abordava questões antropológicas no pensamento social da psiquiatria no estado de São Paulo'; por outro lado, a minha inserção, em 1990, como professor no curso de Sociologia Médica, da graduação em Medicina na Universidade Federal de São Paulo - E.P.M., anteriormente denominada Escola Paulista de Medicina. Fundamentalmente, essa última experiência colocou-me em contato com os alunos de primeiro ano ${ }^{2}$, quando pude observar a necessidade da aproximação dos futuros médicos com os serviços de saúde e, com especial atenção, para o nível de atenção primária à saúde representado dentro da estrutura institucional da Universidade pelo Centro de Saúde-Escola.

Indagava-me, então, sobre a necessidade de introduzir os alunos nos conhecimentos sobre saúde pública ${ }^{3}$, dentre as outras disciplinas do curso de medicina. A partir daí, voltei minha atenções para o Centro de Saúde-Escola, entendendo-o como canal de acesso para os alunos adentrarem nos conhecimentos sobre os problemas de saúde num

\footnotetext{
${ }^{1}$ Na dissertação de mestrado, cujo título era $A$ Formação da Nacionalidade Brasileira no Pensamento Médico Paulista: o caso de Antonio Carlos Pacheco e Silva, foram discutidos os conceitos de raça e nacionalidade no desenvolvimento da psiquiatria no estado de São Paulo.

2 O curso de Sociologia Médica naquela escola foi inaugurado em 1987. As docentes responsáveis pelo curso, professora doutora Paulete Goldenberg e professora doutora Mara Helena de Andréa Gomes, organizaram o curso com a intenção de introduzir no currículo médico os seguintes eixos teóricos: concepções sobre o processo saúde-doença, organização e desenvolvimento dos serviços de saúde e exercício da profissão médica como prática social.

${ }^{3}$ A noção de saúde pública em questão restringe-se, neste caso, aos aspectos mais genéricos que a área de estudos em saúde comporta. Refiro-me, pois, às questões de saúde mais abrangentes na população, incluindo a discussão sobre os processos de adoecimento em suas relaçőes com a organização dos serviços de saúde nos vários niveis
} 
dimensionamento que tomasse a perspectiva do social, indo além, portanto, do aprendizado dos processos de adoecimento observados de uma perspectiva individual, ou seja, da perspectiva do adoecimento do corpo sem considerar as relaçōes com o meio à sua volta. Era um rumo natural que tomava em minha trajetória profissional, construido a partir da formação na área de Ciências Sociais e as reflexões que pude então construir em meu processo de formação.

Meus interesses voltaram-se, portanto, para a necessidade de entender a organização de um Centro de Saúde-Escola, procurando identificar seu papel e a sua real importância para o ensino e, fundamentalmente, na prestação de serviços de saúde à população. Neste sentido, o tripé assistência, ensino e pesquisa, conjugados dentro de uma só organização, passaram a constituir com maior precisão meus interesses intelectuais e, consequentemente, a construção das idéias que culminaram na elaboração do projeto de pesquisa que viabilizou esta investigação.

Contribuiu em muito nessa trajetória os cursos freqüentados no programa de pós-graduação, através dos quais pude ter acesso à bibliografia que deu suporte à investigação, além de poder compartilhar as reflexões com minha orientadora, meus professores e colegas.

Foi de extrema importância, também, minha participação em trabalhos realizados no Instituto de Saúde (Secretaria Estadual de Saúde) junto ao curso de aprimoramento para formação de pesquisadores em Saúde Coletiva. Além das atividades de ensino desenvolvidas na disciplina de Métodos e Técnicas de Pesquisa Social, pude participar como um dos professores orientadores do projeto de pesquisa intitulado Caracterização do Modelo Técnico-Assistencial dos Centros de Saúde-Escola da Cidade de São Paulo, no período de 1994 a 1995. Daí surgiram os primeiros contatos com o doutor Nivaldo Carneiro Júnior, diretor do Centro de Saúde-Escola Barra Funda, para quem os interesses em promover estudos sobre os serviços em nivel de atenção primária em saúde eram comuns. 
A escolha do Centro de Saúde-Escola Barra Funda ocorre, portanto, a partir de uma articulação entre meus interesses intelectuais e as oportunidades de contato ocorridas no desenvolvimento das atividades profissionais. Nesse percurso chamou minha atenção, inicialmente, a importância que o Centro de Saúde-Escola Barra Funda assumia pelas suas características evidenciadas nos primeiros contatos: a sensibilidade e a dedicação com relação às questōes que envolvem a necessidade de gerar conhecimentos através da pesquisa, encaminhar os projetos de ensino e, fundamentalmente, a reflexão sobre a prática da assistência em suas articulações com as outras duas finalidades.

Quanto à minha curiosidade teórica, ou seja, os estudos antropológicos em administração das organizações, esta foi despertada pela vasta produção de pesquisas empiricas já desenvolvidas pela extensa e antiga tradição antropológica sobre o estudo da cultura e pela necessidade de desenvolvermos a capacidade de construir conhecimentos que ampliem a visão sobre as organizações através da abordagem antropológica.

Neste sentido, a noção de cultura organizacional expressa um potencial de criação desses novos conhecimentos ao localizar em unidades restritas, denominadas organizaçōes, elementos particulares que explicam suas origens, ocorrências históricas e situação presente, caracterizando-a não como agrupamentos sociais isolados do contexto social maior, mas identificando-a em suas relações com este contexto sem perder a riqueza de suas particularidades.

Os mitos, os ritos, os marcos históricos mais significativos, os heróis institucionais e as lideranças espontâneas, são alguns dos elementos de análise que contribuem para a investigação das organizações sem, contudo, excluir um principio gerador da necessidade destas investigações que é o de contribuir para a reflexão sobre as finalidades e realizações que esse tipo de organização, prestadora de serviços públicos em saúde, 
desempenha na sociedade. Há que se considerar o conhecimento como elemento gerador de reflexões que contribuam não só para o entendimento da realidade das organizaçōes, e possiveis intervenções em seus rumos, ao incrementar o diálogo entre o pensamento e as ações que devem ser planejadas e executadas.

A intenção da realização deste projeto de pesquisa não se restringe a um pensamento individual, isolado em suas particularidades pessoais como sugerem essas palavras de apresentação, mas, pelo contrário, a um movimento maior que nos impulsiona a realizar as coisas através do aprendizado sobre o conhecimento, das relações profissionais e afetivas vividas nesse processo, enfim, de nossa experiência de vida. É o que fornece sentido - aos desejos e às suas realizações, nos dá força para criar idéias e, consequentemente, estabelecermos relações sociais. Uma investigação não foge a essa interpretação à medida que expõe, além de nossas intençōes, os nossos limites quanto à sua realização.

Ao indicar a abordagem antropológica como um possivel caminho a ser trilhado dentro do conhecimento científico - dentre outros possíveis, encontra-se subjacente uma intenção construída durante as fases anteriores de nossa formação. Qualquer motivo ou evento justificaria nossas intenções na produção de investigaçōes científicas. Por exemplo, o encanto despertado desde os primeiros contatos com a produção científica em Ciências Sociais, ou o carisma e a sensibilidade de alguns professores ao dialogarem com seus alunos expondo suas idéias ou a de outros pesquisadores, até a sensibilidade despertada pelas questōes sociais tão problemáticas nesses e em tempos passados. Ou todas essas coisas juntas.

A abordagem antropológica, em especial o conceito de cultura, propiciou essa sensibilidade em pensar questões particulares sobre a sociedade brasileira. A associação com a área de saúde, desenvolvida principalmente em minha atuação profissional, aproximou essas áreas de conhecimento para formar um síntese entre, de um ponto de vista mais geral, a análise da cultura e da saúde, e, mais particularmente, uma análise 
que contemplasse o ensino e a assistência na área de saúde a partir do enfoque antropológico. A análise de cultura organizacional implica um levantamento e interpretação de uma realidade especifica porque criadora, em sua dinâmica histórica, de um conjunto próprio de símbolos e significados que a identificam como única, apesar das semelhanças institucionalizadas por um modelo oficial de organização dos serviços.

A contribuição deste trabalho estaria, portanto, na reflexão que a abordagem antropológica pode trazer à própria organização ao levantar informações importantes e interpretá-las, lançando-as, neste movimento reflexivo, a pensar uma determinada realidade para e com seus próprios realizadores.

Numa instância prática, a relevância deste trabalho de investigação é a de que o mesmo se insere num conjunto de intenções e práticas já encaminhadas pelos que gerenciam ou atuam profissionalmente no Centro de Saúde-Escola Barra Funda. Interessa a alguns profissionais o desenvolvimento de metodologias de pesquisa não convencionais em seus limites, ou seja, interessa-lhes experimentar metodologias que abordem problemas de interesse atual na unidade de saúde de outras perspectivas. Neste caso, procuram cercar as abordagens oferecidas pelas metodologias que valorizam a busca da qualidade e, por conseguinte, o entendimento do significado dos fenômenos que cercam aquela realidade, seus enfoques diferenciados e, também, seus objetos de investigação que são diferenciados das abordagens comuns à pesquisa experimental ${ }^{4}$.

Um outro aspecto seria a possibilidade de retornar sinteticamente os principais elementos levantados durante a pesquisa - vale lembrar que o momento da coleta de dados já consiste numa intervenção à medida que lança os informantes a pensarem de forma dirigida naquilo que realizam no cotidiano $^{5}$ - que possibilitem o repensar da prática profissional, a organização do serviço e, fundamentalmente, o campo onde encontram

\footnotetext{
${ }^{4}$ Cf. Chizzotti, A., Pesquisa em Ciencias Humanas e Sociais, 1995.

${ }^{5}$ Cf. Queiroz, M.I.P., Variaçठes sobre a Técnica de Gravador no Registro de Informaçăo Viva, 1983
} 
concepções diferenciadas sobre a saúde e a doença, os serviços de assistência e ensino, além da pesquisa que assume maiores proporções na atualidade daquele centro de saúde-escola.

A abordagem antropológica pode contribuir, também, para evidenciar outros aspectos das relações sociais muitas vezes não contemplados em estudos que têm como enfoque as relaçōes de trabalho, a gerência, ou mesmo a programação em saúde. $O$ enfoque antropológico não cobre, evidentemente, todos os aspectos da vida social - até porque o objeto de investigação deve delimitar claramente a abrangência do trabalho de investigação, o que cria a possibilidade para esta pesquisa de tão somente ampliar as possibilidades de trazer à tona evidências que promovam o debate sobre a atuação da organização.

A noção de cultura organizacional, neste sentido, define teoricamente o campo de observação, possibilitando recortes multidirecionais que perpassam as concepções sobre o trabalho, as relações internas entre os agentes e suas formações especificas e, fundamentalmente, uma história particular revisitada através de publicações e depoimentos que possibilitem refletir em profundidade sobre as relaçōes sociais dentro da organização e o seu papel perante a sociedade.

Espero, portanto, poder contribuir à tão generosa acolhida da direção e das pessoas que atuam no Centro de Saúde-Escola Barra Funda. Uma pequena contribuição, evidentemente, perto da grandeza do trabalho realizado junto à população da área central da cidade de São Paulo e dos alunos que por lá passam para cumprir estágios ou disciplinas curriculares. Um trabalho sem dúvida alguma significativo para o desenvolvimento da saúde da população.

A apresentação deste relatório de pesquisa está subdividida nas seguintes partes: Introdução, na qual o objeto de investigação, assim como os objetivos de pesquisa são apresentados; Capítulo 1, contendo o corpo teórico e a problematização dele derivada; Capitulo 2, apresentação do quadro metodológico em seus aspetos teóricos e técnicos; Capítulo 3 , 
histórico da organização e indicativo da principais referências teóricas em saúde pública que nortearam o projeto de formação do Centro de SaúdeEscola; Capítulo 4, discussão das informações coletadas junto aos funcionários da unidade de saúde; e, por fim, as Considerações Finais. 


\section{INTRODUÇÃO}

Ao dar inicio às primeiras formulações que possibilitaram a execução deste projeto de pesquisa, alguns questionamentos foram elaborados e dirigidos no sentido de poder organizar o processo de pesquisa cuja temática do estudo de cultura organizacional de uma unidade básica de saúde teve a sua definição originada a partir de uma questão prática: as mudanças ocorridas no perfil da população da área de abrangência do Centro de Saúde-Escola Barra Funda, as quais promoveram uma série de questionamentos e mudanças nas práticas internas ao serviço.

Preocupei-me, inicialmente, em identificar como 0 assunto sensibilizava a direção da unidade de saúde, assim como as repercussões percebidas entre os funcionários. Seja qual fosse o movimento interno promovido (recusa em assistir novos segmentos sociais até então não assistidos pela unidade, aceitação, abertura para pensar estas questōes, busca de formação contínua e atualização), as suas implicações com o fato de ser um centro de saúde-escola deveriam necessariamente produzir questionamentos internos que viabilizassem a divulgação de novas concepções e práticas no desenvolvimento da prestação de serviços, por um lado, e no ensino e pesquisa, por outro.

A partir daí, foram formuladas algumas perguntas que viabilizassem o estudo. Foi pensado, inicialmente, qual seria o impacto causado na prática profissional dos agentes de saúde em decorrência da mudança lenta e gradual do perfil da clientela nas duas últimas décadas. Caberia a seguinte pergunta: quais as mobilizações ocorridas tanto no pensamento, cercando as concepções produzidas pelos agentes durante 0 processo, como da própria prática interna, na realização de tarefas programadas e no cumprimento dos fluxos de trabalho estabelecidos previamente? 
Dos questionamentos expostos acima decorreu um outro: como ocorrem as articulações internas entre setores e categorias profissionais no entendimento e na prática do trabalho com relação a estas mudanças? Ou seja, como estas questões são colocadas num plano mais geral da organização, saindo portanto da esfera individual de atuação dos profissionais?

Num outro sentido, qual o papel das pesquisas realizadas na unidade tendo por suposto a sua capacidade servir de instrumento teórico e de criação de novas formas de trabalho que contemplem as novas demandas e necessidades colocadas pela população? A qualidade de ser um Centro de Saúde-Escola, neste caso, traz um significado especial à análise desta questão, posto que, dentre as suas finalidades, aquela de desenvolver o conhecimento é fundamental já que possibilita, também, a adequação de um programa de ensino sempre atualizado.

Esses questionamentos vieram seguidos de uma última pergunta: quais as marcas imprimidas pelas concepções e práticas de um centro de saúde-escola que, em suas origens, denominava-se experimental, o que the concedeu a prerrogativa da autonomia de experimentar novas formas de organização dos serviços e treinar o pessoal no próprio serviço?

Colocadas estas perguntas introdutórias, foram levantados elementos teóricos que viabilizassem a construção de uma problematização, a qual deveria unir as evidências concretas às questões teóricas. A primeira distinção é a definição de organização enquanto elemento único e, por isso mesmo, produtor de uma história particular cujo contexto social maior de sua inserção promove transformações profundas.

Neste sentido, a idéia de que a organização enquanto unidade separada e ao mesmo tempo atuante no contexto maior que a cerca, guardaria as suas particularidades a medida que pudéssemos entender a gama de símbolos e significações próprios criadas em sua história particular. Ritos, mitos, formas particulares de representações são algumas das categorias teóricas possiveis de serem estudadas neste caso, as quais 
contribuem para o desenvolvimento de um conhecimento de uma realidade única, particular.

A produção de serviços, o ensino e a pesquisa cultivados pela organização são os parâmetros que delimitam a abrangência do estudo o que, num certo sentido, não limita as possibilidades de uma análise que contemple as relações com o sistema maior que envolve a organização dos serviços, por um lado, e as escolas médicas, por outro lado.

Feitas estas considerações iniciais, passo às definições conceituais que nortearam a pesquisa, fornecendo-lhe sua base de pensamento e orientando nas sinteses produzidas. A abrangência destas definições conceituais teve seus limites ampliados pela complexidade exigida pela área de estudos em saúde, a qual concentra uma variedade de abordagens teóricas justificada pela sua principal característica: a de ser multifacetada. 


\section{CAPÍTULO 1 - DEFINIÇÕES CONCEITUAIS}

Serão apresentadas, neste capítulo, consideraçōes sobre a rede de serviços em saúde prestados à população, indicando as possibilidades de organização dos sistemas de assistência em suas formas concretas. Com isso, podem ser indicados com precisão as definiçōes de unidade básica de saúde, designação que indica um posicionamento especifico dentro do sistema dado pela sua condição de ser um serviço básico, e de Centro de Saúde-Escola, forma derivada da primeira mas que se diferencia pela sua qualidade ao lidar com o ensino.

A partir da apresentação dos elementos teóricos indicados acima, - passo seguinte consiste na discussão centrada na abordagem antropológica que será problematizada num âmbito mais geral, a qual incluirá suas potencialidades em estudos das sociedades contemporâneas, terminando por concluir com a apresentação da noção de cultura organizacional.

Com relação à organização dos serviços de saúde, uma primeira distinção a ser apontada é aquela que separa os setores público e privado enquanto dois grandes grupos prestadores de assistência à população. Dentro dos mesmos há subdivisões estabelecidas, separando-os tanto no aspecto da organização setorial como da origem do capital investido. Por exemplo, enquanto o setor público está subdividido nas esferas de governo federal, estadual e municipal, o setor privado está subdividido em dois blocos: por um lado, os serviços cuja finalidade é a obtenção de lucro e, por outro, os denominados não lucrativos'.

\footnotetext{
${ }^{1}$ Cf. Elias, P.E., Estrutura e Organizaçăo da Atenção à Saúde, 1996. O artigo fornece uma reflexão valiosa sobre a organização dos serviços de saúde no contexto do SUS (Sistema
} 
O setor público tem como principal característica a de ser financiado com recursos orçamentários governamentais, estabelecendo como principio de organização o livre acesso da população à sua rede de serviços, além de se caracterizar como um setor submetido a mecanismos de controle social, o que nem sempre ocorre. (ELIAS, 1996:73)

Por outro lado, o setor privado com fins lucrativos pode ou não manter vínculos com o setor público em forma de convênio. Quanto às instituições privadas sem fins lucrativos que prestam serviços à população, estas podem ser organizadas tanto por grupos religiosos quanto por outros agrupamentos civis que, em sua maioria, dependem do Estado enquanto fonte principal de financiamento. Podem ser indicadas como exemplo desse tipo de instituição, no Brasil, as Santas Casas de Misericórdia. ${ }^{2}$

Com relação à rede de serviços de assistência oferecida à população, há estabelecimentos pertencentes ao setor público e ao setor privado. Os estabelecimentos de menor complexidade, em termos de sua composição dos recursos humanos e tecnológicos disponiveis e também considerados a porta de entrada do sistema como um todo, são aqueles denominados de postos de saúde e os centros de saúde. O primeiro se caracteriza por assistir a uma população de uma regiăo específica, geralmente com uma localização distanciada de centros urbanos mais populosos; é sua característica, também, a não incorporação de equipamentos e recursos humanos de nivel superior, constando do quadro de pessoal tão somente funcionários com formação nos níveis escolares fundamental ou médio.

Quanto aos centros de saúde, a diferença que os distingue do anterior é a complexidade apresentada no que diz respeito à incorporação

\footnotetext{
Único de Saúde) no Brasil, destacando a questão do financiamento do sistema numa análise centrada no conceito de Estado.

${ }^{2}$ Cf. sobre hospitais filantrópicos, Guedes, J. da S. et al, Os Hospitais Filantrópicos e Beneficentes e sua Inserção nos Sistemas Unificados e Descentralizados de Saúde - SUDS no Brasil, 1988. E elucidativo o seguinte trecho transcrito a seguir: "Em 1987, a criação dos Sistemas Unificados e Descentralizados de Saúde (SUDS) em diversos estados tem entre seus principais objetivos a universalização da clientela e a incorporação dos hospitais
} 
de tecnologias reduzidas, tais como, capacidade para realização de alguns exames laboratoriais, aparelho de raio " $X$ ", etc. São incorporados em seu quadro de pessoal funcionários com formação universitária (enfermeiros, médicos, psicólogos e assistentes sociais, etc.), além de pessoal com formação nos niveis fundamental e médio. (ELIAS, 1996: 74)

Segundo as normas estabelecidas pelo Ministério da Saúde ${ }^{3}$, os centros de saúde são unidades dentro do sistema que têm a responsabilidade de cuidar da saúde coletiva. São suas funções básicas, segundo este documento, a fiscalização sanitária para a melhoria das condições de higiene da população, tais como, coleta de lixo domiciliar, proteção de fontes de abastecimento de água, sistema de coleta de esgoto nos bairros, entre outros. É sua função, também, o cumprimento de açōes de saúde junto à população, cuidando das doenças transmissiveis, das crônico-degenerativas, dos cuidados odontológicos, alimentares e de nutrição. Estas ações devem estar estruturadas e organizadas segundo uma ordenação que estabeleça a divisão da população assistida por faixa etária e por sexo. (MS, 1982)

Em relação aos centros de saúde-escola, durante os anos 60 , no Brasil, seu surgimento ocorre no bojo do desenvolvimento de movimentos que propunham algumas reformas na organização dos serviços de saúde ${ }^{5}$. Pode ser destacada a concepção sobre Medicina Comunitária que ampliou as perspectivas e a prática do ensino médico, ao desenvolver o ensino fora

filantrópicos e beneficentes como integrantes do sistema de saúde, em parceria com os serviços de saúde dos governos estaduais e municipais" (GUEDES, J. da S. et al, 1988: 13) ${ }^{3} \mathrm{Cf}$. MS - Ministério da Saúde, Normas e Manuais Técnicos, 1982.

${ }^{4}$ Sobre a formação e a história dos centros de saúde no Brasil, cf. Mendes Gonçalves, R.B. (1986) e Cyrino (1993).

${ }^{5}$ Cf. Cyrino, A. de P.P., Organizaçăo Tecnológica do Trabalho na Reforma das Práticas e dos Serviços de Saúde: Estudo de um Serviço de Atençăo Primária à Saúde, 1993. As origens de centros da saúde vinculados a escolas médicas é resgatada pelo autor a partir da análise dos modelos teóricos que orientaram a organização dos serviços, resgatando, também, as concepções de medicina integral, medicina preventiva e medicina comunitária e destacando os centros de saúde-escola como parte importante dos serviços de saúde pelas caracteristicas fundamentais que os mesmos deveriam assumir: a qualidade de serem experimentais. 
dos hospitais ${ }^{6}$, cabendo às escolas testar novas formas de organização dos serviços de saúde, além de ensinar aos alunos de medicina a estrutura e funcionamento desse tipo de organização, ampliando o campo de visão através do conhecimento sobre a população e sobre os processos de adoecimento. A proposta da Medicina Comunitária não constituiu um novo campo de debate teórico, pois estava fundada em principios já elaborados anteriormente nas propostas de medicina integral e da medicina preventiva. Fundamentalmente, a idéia era a de ser difundida a prestação de serviços aos segmentos da população até então excluidos dos cuidados médicos e sanitários, passando a cuidar, a partir daquele momento, da estrutura social como um todo. DONNANGELO (1976) formulou as seguintes considerações sobre o desenvolvimento histórico da medicina comunitária enquanto prática:

"Como projeto de reforma médica a Medicina Comunitária retoma e reorienta as questões já postas no campo de problemas e tentativas de solução que cercam a prática médica. Postula, na seqüência da medicina integral e da medicina preventiva, a subordinação da prática à dimensão social do processo saúde-doença, impondo a superação do corte entre aspectos orgânicos e psicosociais, entre condutas preventivas e curativas, entre prática individual e efeitos coletivos da atenção à saúde. Apresenta-se igualmente como uma resposta à inadequação da prática médica para atender as necessidades de saúde das populaçōes, necessidades que devem ser solucionadas tanto como resposta ao princípio do direito à saúde como por sua significação para o processo de desenvolvimento social. Mas localiza os elementos responsáveis pela inadequação não apenas

6 Sobre o desenvolvimento da medicina comunitária, Donnangelo, M.C.F., Saúde e Sociedade, 1976, tece as seguintes considerações: "É como prática de saúde, como forma de prestação de serviços, antes que como um campo sistematizado de princípios que a Medicina Comunitária se origina nos Estados Unidos e se difunde para as sociedades dependentes com o suporte das agências internacionais tais como a Organização Mundial de Saúde e Organização Panamericana de Saúde. Na América Latina a difusão do projeto ganha corpo na década de 70 e resulta em programas experimentais de prestação de serviços que se propõem o desenvolvimento de modelos de assistência passiveis de garantir a extensão do cuidado à saúde a populações pobres, urbanas e rurais. Também aí - projeto aparece, em uma de suas dimensőes, como prática altemativa paralela à organização dominante [o hospital] de assistência médica." (DONNANGELO: 1976, 85) 
nos aspectos internos ao ato médico individual, mas sobretudo em aspectos organizacionais da estrutura de atenção médica superáveis através de novos modelos de organização que tomem como base o cuidado dos grupos sociais, antes que dos individuos. Por essa via dirige-se não apenas para a reformulação do ato médico, mas para uma nova articulação do conjunto de agências e práticas que compõem o campo da atenção à saúde.

(...) A experimentação de modelos, mais do que um modelo organizacional específico constitui o núcleo da proposta da Medicina Comunitária, mas o elemento de prestação de serviço - sob a forma de mais numerosos ou de novos serviços - aparece desde o início como impositivo. E à escola médica, entre outras agéncias, incumbe a elaboração e a experimentação desses modelos, experimentação que servindo também a outros modelos deve corresponder já efetivamente, à prestação de serviços à comunidade." (DONNANGELO, 1976: 86)

É dentro desse espaço privilegiado e dirigido à criação de novas formas de organizar os serviços, que as escolas de medicina passaram a desenvolver a aproximação de seus alunos com uma realidade social obscurecida até então pelo ensino dentro dos limites impostos pelos hospitais de ensino. Fundamentalmente, a idéia de centro de saúde baseada na proximidade com uma população de uma determinada região, consistiria na prática de manter sob seu controle o conhecimento sobre a dinâmica do perfil epidemiológico de uma determinada área, oferecendo os seus serviços de acordo com as necessidades levantadas, cumprindo algumas programações estabelecidas a priori, ou mesmo atendendo à demanda espontânea que busca nos serviços soluçōes para seus problemas de saúde.

A sua funcionalidade estaria, portanto, amparada na sua principal característica: a de irradiar a partir de um ponto central seu olhar e detectar ao redor, dentro de limites regionais estabelecidos, quais os problemas de saúde ou problemas sanitários que possam conduzir os vários segmentos da população a processos de adoecimento. A perspectiva da centralidade, constituindo um campo privilegiado de quem olha e atua, procura penetrar 
nos meandros da dinâmica social estabelecida numa determinada região, repensando sua prática de acordo com esse movimento contínuo da realidade social. O fluxo estabelecido entre o olhar - fundado na organização tecnológica do trabalho, na formação técnica dos vários profissionais envolvidos e, também, na prática profissional de cada agente social inserido nesse serviço - e o retorno desse olhar à prática do serviço, seja repensando-o ou transformando-o, deve, pois, constituir um espaço de questionamentos onde os posicionamentos de cada agente social vão também se transformando, alimentados que são pelos elementos de uma dinâmica social vivida pelos mesmos no dia-a-dia de suas atividades, assim como no envolvimento com a população que procura os serviços, ou é procurada pelo mesmo através das visitas domiciliares.

A compreensão do que seja um centro de saúde-escola passa necessariamente pela compreensão do âmbito administrativo maior no qual está inserido, seja no plano das concepções sobre o processo saúdedoença, seja nas alteraçōes provocadas pelas mesmas na prática dos serviços. Os elementos anteriormente apresentados indicam, de forma resumida, algumas noçōes de como estão estruturados os serviços de saúde, assim como as concepções que fornecem a base dessa estrutura. $A$ inserção de um centro de saúde-escola deve, portanto, ser entendida como pertencente a um corpo maior que fornece não só as diretrizes administrativas e formais para sua existência, como também às concepções que norteiam e dão sentido às suas realizações, correspondendo às exigências imediatas através de uma prática baseada em projetos alicerçados em concepções que indicam os caminhos do olhar e das ações em saúde.

Nesse sentido, é importante a análise desenvolvida por ALBUQUERQUE (1978) que delimita em seu estudo sobre uma agência de saúde o objeto da prática institucional. Vejamos a seguinte passagem:

"(...) Se atentarmos para os diversos elementos que estruturam a prática institucional, veremos que a prática 
dos atores concretos não é resultado, mas componente estrutural da ação das instituições; e que a prática institucional não existe senão encarnada na prática dos atores concretos que a constituem" (ALBUQUERQUE, 1978: 4).

O autor dá continuidade ao seu raciocinio definindo os seguintes elementos para análise de uma agência de saúde:

1. o objeto institucional: “(...) É aquilo sobre cuja propriedade a instituição reivindica o monopólio de legitimidade. Definir-se como instituição é, portanto, apropriar-se de um objeto. Nesses termos, o objeto institucional não pode ser um objeto material, como os recursos de uma organização, mas imaterial, impalpável, e o processo de apropriação desse objeto é permanente, como processo de desapropriação dos indivíduos ou de outras instituições, no que concerne ao objeto em questão".

2. O âmbito institucional: "O que sustenta o objeto social são relações sociais, o que de resto, vale para todo objeto social. A propriedade do objeto, ou sua guarda, é o que autoriza a atuação institucional sobre as relações sociais que sustentam esse objeto. $O$ âmbito de uma instituição deve ser definido, portanto, a partir das relações sociais que inclui, e não em função de suas fronteiras materiais."

3. os atores institucionais: "Se definirmos como instituição uma estrutura de práticas institucionalizadas, isto é, que tendem a se reproduzir e se legitimar, definindo, portanto, uma instituição como estrutura, ela não poderá existir, senão na prática dos atores concretos que a constituem praticando-a. $\mathrm{Na}$ análise das instituições os atores institucionais são, portanto, o elemento estruturador por excelência. Uma instituição só existe na prática de seus atores institucionais, prática que consiste em 
intervir nas relações sociais submetidas à soberania da instituição." (ALBUQUERQUE, 1978: 5-8)

Sob este enfoque, portanto, as relaçōes sociais internas a uma organização podem ser pensadas com maior precisão e com as garantias de serem descritas e analisadas sem que sua base de pensamento, fundada nas concepções que norteiam a organização dos serviços, esteja dissociada de uma prática legitimada institucionalmente $e$, por conseguinte, legitimada socialmente pelo seu reconhecimento, tanto pelos que nela atuam como pela população que dela se utiliza.

Quanto aos atores institucionais, estes têm garantida a sua inserção, assim como permanência nos quadros funcionais, a partir da legitimidade conferida à suas formações, podendo portanto realizar dentro do âmbito institucional aquilo que lhes é atribuído. Tomamos aqui as categorias elaboradas por ALBUQUERQUE (1978) sobre os atores institucionais definindo-os da seguinte forma:

1. agentes privilegiados: categorias profissionais cujo saber e o poder são reconhecidos institucionalmente e a prática concretiza imediatamente a ação institucional; por exemplo, médicos;

2. agentes subordinados: são igualmente profissionais subordinados (enquanto categoria profissional) aos privilegiados; têm menos autonomia com relação ao objeto institucional; são estudantes de medicina, enfermeiros e outras profissões em saúde;

3. pessoal: são empregados ou funcionários da instituição, mas atuam diretamente ligados à ação institucional; por exemplo, administrativo, manutenção, apoio em geral.

Ao delimitarmos, portanto, o espaço institucional a partir dessas categorias indicadas acima, criamos a possibilidade de uma definição mais 
precisa do que seja uma organização e, neste caso especifico, uma organização de saúde.

No sentido mais estrito, podemos entender o termo organização como um conjunto de pessoas agrupadas sob um comando, ou um comando segmentado e hierarquizado, para um trabalho coordenado. Em outras palavras, "(...) a organização é um instrumento de trabalho racionalmente concebido para a mobilização e coordenação de esforços no cumprimento de propósito específico. Seu valor, interna e externamente, depende de sua capacidade para atingir de forma eficaz os objetivos em vista."

Tendo por referência a noção de organização explicitada acima, algumas consideraçōes sobre organizaçōes em saúde são necessárias, sendo que, neste caso particular de investigação sobre um único centro de saúde-escola, são necessários, também, alguns apontamentos que delimitem o grau de isolamento e autonomia existente, elementos estes que contribuem para uma caracterização da organização e de seus vínculos externos.

Segundo LIMA (1994), as organizações de saúde guardam particularidades não encontradas em outras organizações. A passagem transcrita a seguir indica alguns parâmetros que as definem com maior precisão:

"As organizações de saúde constituem-se, predominantemente, em organizações profissionais, porque seu funcionamento depende de seus operadores - os profissionais responsáveis pela produção de seus serviços. Eles são os recursos críticos dessas organizações, sem os quais elas não poderiam funcionar nem alcançar os objetivos em função dos quais foram criadas (...). Esses profissionais preservam grande autonomia em relação ao trabalho que desenvolvem, pois

\footnotetext{
${ }^{7}$ Cf. F.G.V., Instituto de Documentação, Dicionário de Ciências Sociais, 1987. O termo organização traz uma série de controvérsias quando usado o termo instituição com o mesmo significado. A passagem transcrita a seguir procura defini-lo da seguinte maneira: (...) O termo instituição aplica-se a grupos que, através da dinâmica de seu funcionamento, se revestem de significado especial para seus membros e para a comunidade que constitui - seu ambiente. Passam a ser valorizados por eles mesmos e não apenas por sua funcionalidade como instrumento para a realização de dada tarefa". (F.G.V., 1987: p. 612)
} 
são os únicos que possuem as habilidades $e \quad o$ conhecimentos necessários ao desenvolvimento e ao julgamento de seu trabalho." (LIMA, 1994: 40)

Uma outra características importante a ser ressaltada no entendimento das organizaçōes de saúde, é a distinção existente entre o grupo de profissionais admitidos numa organização de saúde. Há, portanto, uma "intensa divisão e especialização do trabalho", fragmentando as organizações em segmentos. Aqui o problema está em aproximar aquilo que a formaçăo separa de um objetivo fundamental: a interdisciplinaridade da atenção à saúde no trabalho conjunto dos profissionais envolvidos. Segundo LIMA (1994), "O produto final - o paciente atendido - é resultado de inúmeras intervenções e da utilização de diferentes subprodutos desenvolvidos por diferentes setores e profissionais dos serviços de saúde." (LIMA, 1994: 41)

As consideraçōes explicitadas anteriormente definem, de forma genérica, algumas consideraçōes sobre as organizaçōes em saúde não especificando as particularidades, por exemplo, que diferem hospitais de centros de saúde. Deve ser considerado, portanto, como finalidade maior de um centro de saúde, além dos cuidados médicos, o controle sobre a população de sua responsabilidade, identificando os problemas de saúde locais, o controle sanitário da área, a promoção da saúde através de práticas associadas ao atendimento médico e, também, à educação em saúde.

São essas particularidades que definem os centros de saúde, dentro da instância da atenção primária à saúde, como organizaçōes mais próximas ao cotidiano da população. Suas atribuições e seu vinculo com as outras instâncias $^{8}$ de assistência médica o tornam a porta de entrada do sistema à medida em que devem servir de referência para a população sob

\footnotetext{
${ }^{8}$ Cf. Elias, P.E., 1996. São considerados os niveis de atenção à saúde a assistência domiciliar, a atençăo primária à saúde através dos postos e centros de saúde, a atençăo secundária com caracteristicas curativas representada por ambulatórios e hospitais e a atençăo terciária representada por hospitais de ensino.
} 
a sua responsabilidade. Há de se considerar, portanto, que em termos estratégicos os centros de saúde devem manter uma sensibilidade de precisar com exatidão as necessidades de uma determinada população, sem o que não haveria sentido a sua existência.

\section{A abordagem antropológica e o conceito de cultura organizacional}

Feitas as considerações iniciais sobre a organização dos serviços de saúde e uma caracterização genérica sobre os centros de saúde e seu papel no sistema de saúde como um todo, são necessárias algumas definições conceituais que indiquem os limites e possibilidades do conceito de cultura organizacional dentro da proposta de investigação colocada por essa pesquisa. Antes, porém, é importante situar o debate sobre o conceito de cultura dentro da abordagem antropológica, cercando alguns aspectos de sua evolução e, principalmente, a passagem dos estudos de sociedades exteriores ao do próprio pesquisador para estudos sobre o cotidiano dentro do espaço urbano. Ou seja, o desenvolvimento de estudos que envolvam grupos populacionais até então observados pela sociologia, principalmente pela perspectiva da análise de classes sociais.

A antropologia pôde contribuir com o estudo dos microcosmos, do particular, sem contudo perder-se numa etnografia urbana constituída tão somente de referências empiricas sem maiores conseqüências teóricas que Ihe dão sentido a medida que explicam os fenômenos sob os quais se debruça. Segundo DURHAM (1986), a antropologia, desde as suas origens, "dedicou-se muito mais ao estudo da família, da religiāo, do folclore, da medicina popular, das festas do que à análise do Estado, dos partidos políticos, dos movimentos sindicais, das relações de classe, do desenvolvimento econômico" (DURHAM, 1986: 18). Na definição da autora, eram temáticas periféricas à grande "arena das lutas políticas." (DURHAM, 1986: 18)

Comentando as mudanças em seus estudos, a autora afirma o seguinte sobre a antropologia: 
"O sucesso (...) da antropologia está certamente vinculado ao fato de que, hoje, essas minorias desprivilegiadas emergem como novos atores políticos, organizam movimentos e exigem uma participação na vida nacional da qual estiveram secularmente excluídos. Mais ainda, temas como a religião ou a sexualidade, o papel da mulher na familia e a medicina popular parecem ter se politizado de um momento para outro, passando a possuir uma nova importância na compreensão da dinâmica da transformação da sociedade brasileira. Dessa forma, o conhecimento acumulado pela antropologia no tratamento desses temas, assim como sua competência especifica no trabalho de campo com essas populações, tornaram-se subitamente relevantes politicamente." (DURHAM, 1986: 18)

$\mathrm{Na}$ seqüência de seu pensamento, a autora faz menção à produção teórica em antropologia no Brasil:

"Parece portanto oportuno, nesse momento, uma reflexão crítica sobre o conjunto da produção antropológica recente no Brasil. $E$ se essas consideraçōes parecem pertinentes para a antropologia em sua totalidade, são ainda mais relevantes para as pesquisas que estão sendo feitas com populações urbanas. (...) Com efeito, esse tipo de investigação tem uma longa tradição na antropologia brasileira. $E$, desde o começo, trata-se menos de uma antropologia da cidade do que de uma antropologia na cidade. Isto é, não se desenvolveu no Brasil uma antropologia urbana propriamente, nos moldes em que foi iniciada pela Escola de Chicago, uma tentativa de compreender o fenômeno urbano em si mesmo. Ao contrário, trata-se de pesquisas que operam com temas, conceitos e métodos da antropologia, mas voltados para o estudo de populações que vivem nas cidades. A cidade é, portanto, antes o lugar da investigação do que seu objeto." (DURHAM, 1986: 19)

${ }^{9}$ Cf. Durhan, E., A Perspectiva Antropológica em Populaçס́es Urbanas: Problemas e Perspectivas, 1986. A autora recupera em seu artigo uma breve e interessante história dos estudos antropológicos no Brasil, indicando os primeiros estudos realizados pelo médico maranhense Raimundo Nina Rodrigues, passando pela tradição culturalista cujo expoente maior foi Gilberto Freyre, além de citar a tradição funcionalista que vigorou nos estudos antropológicos brasileiros durante décadas, a tradição estruturalista e a abordagem marxista na antropologia. Sobre as origens e a evolução da antropologia no Brasil, conferir, 
A ocorrência do deslocamento do objeto da antropologia para os estudos realizados nas sociedades industrializadas promoveu uma série de investigações que não deixaram paralisar a produção de conhecimento das "outras" sociedades. Pelo contrário, segundo GOLDMAN (1996):

"Um dos traços mais marcantes do desenvolvimento das
pesquisas antropológicas nos últimos 50 anos parece ser
o progressivo deslocamento de seu objeto. Se até a
década de 40 a antropologia podia, com certa justiça, ser
considerada a 'ciência das sociedades primitivas'
(concepção que subsiste até hoje, mesmo no senso
comum ilustrado), a partir de então aquilo que, por
contraste, se convencionou denominar 'sociedades
complexas' passou a atrair, cada vez mais, a atenção dos
antropólogos.
Isso não significou abandono do estudo das 'outras'
sociedades, mas uma problematização da própria noção
de alteridade, convertendo nossa sociedade em objeto de
estranhamento, observável de uma perspectiva 'outra'
(...)." (GOLDMAN, 1996)

Em artigo publicado em 1991, MONTERO debate sobre os rumos da antropologia a partir do seguinte questionamento: "como a antropologia, que forjou seu instrumental de análise na observação de sociedades 'frias'", poderá dar conta do intenso dinamismo que define as relações sociais no mundo contemporâneo?" (MONTERO, 1991: 114) Seu debate vai se desenvolver levando em consideração três aspectos cruciais, a saber:

1. as transformações dos objetos antropológicos;

2. a crise correlata de seus instrumentos conceituais (fundamentalmente 0 de cultura, entre outros); e,

também, Corrêa, M., As llusర̃es da Liberdade: a Escola Nina Rodrigues e a Antropologia no Brasil, 1982.

${ }_{10}$ Goldman (1996) discute neste mesmo artigo a oposição entre sociedade simples e complexa, a qual marcou durante décadas, e ainda marca, os estudos antropológicos.

${ }_{11}$ A autora faz alusão à obra de Claude Lévis-Strauss, O Pensamento Selvagem, que separa a história das sociedades nas categorias de fria e quente, indicando o sentido de mais lentas e mais aceleradas. 
3. a transformação de suas finalidades e métodos.

Neste sentido, sua análise do conceito de cultura vai percorrer a formação e o desenvolvimento do mesmo, assim como as suas possibilidades teóricas no entendimento das sociedades contemporâneas, tendo em vista as preocupações com a questão dos "primitivos" enquanto uma questão de migrantes trabalhadores, turismo intensificado, etc. Ou seja, o contato entre culturas é intensificado na atualidade "(...) ao mesmo tempo em que a diversidade se incorpora e reproduz no interior das sociedades complexas, o conceito antropológico de cultura deixa de ser um instrumento nas mãos de especialistas e se difunde por outros setores da sociedade contemporânea" (MONTERO, 1991: 115) ${ }^{12}$

A autora completa seu raciocinio incluindo a idéia de mundialização e as transformações provocadas por este fenômeno, principalmente pelas contribuições que os conceitos antropológicos podem dar ao explicarem a nova realidade. Por exemplo, "a incorporação desigual das nações no sistema mundial e fatores internos à própria lógica do capitalismo têm reposto e renovado com rapidez as diferenças entre grupos, culturas e nações", gerando novos valores coletivos e a construção de legitimidades sociais entre grupos de mulheres, negros, jovens, etc., a partir do acirramento dos conflitos entre os grupos que formam o conjunto de forças das sociedades. (MONTERO, 1991: 118)

Os processos culturais, neste sentido, indicariam o campo da cultura "como uma das principais arenas da disputa política e da produção de legitimidades" (MONTERO, 1991: 119) consubstanciadas na produção de símbolos. Os processos sociais, por sua vez, ao serem estudados pela ótica da antropologia, passam a ser entendidos através da redução do conceito de cultura a aspectos parciais da vida social e não mais em estudos sobre a totalidade, o que a torna uma ciência em busca do

12 “(..) Um exemplo recente desse fenômeno está no relatório final da Conferência Internacional da Unesco de 1982 no México. (...) A mesma tendência já estava, por 
relativismo que não explica a realidade de sociedades que conjugam uma grande variedade de expressões culturais, conforme o trecho transcrito a seguir:

"Por mais diminuto que seja o recorte que se faça da realidade e por maior que seja sua coerência interna, este objeto estará necessariamente permeado por relaçōes cuja lógica os ultrapassa. (...) É preciso que a antropologia seja capaz de pensar o poder, o conflito $\theta$ a mudança em sociedades em que a totalidade não está inscrita na sua organizaçäo." (MONTERO, 1991: 120)

A autora conclui seu raciocínio propondo o deslocamento da análise para as mediaçōes simbólicas, as quais são compostas pela identidade, ou seja, a maneira como um grupo se vê, como o grupo articula seus objetivos práticos com seus valores e entender as experiencias vividas enquanto fontes de representações que dão forma à identidade e sentido aos membros do grupo. (MONTERO, 1991: 122)

"Não se trata apenas de dizer que os símbolos são usados como instrumentos de poder. É preciso saber por quem, quando, como e contra o que se constróem nossos símbolos. É preciso elaborar uma teoria que seja capaz de perceber, ao mesmo tempo, o modo como a variedade de experiências são produtoras de certas representaçōes da sociedade e como o pensamento social e político hegemônico se enraíza no cotidiano. É preciso que uma análise das lógicas próprias à circulação do simbólico supere o abismo que separa as etnografias do cotidiano das sociologias do poder." (MONTERO, 1991: 123)

\section{As organizações e o estudo dos microcosmos}

Colocado o problema pela perspectiva antropológica, torna-se fundamental situar o estudo das organizaçōes com relação às implicaçōes em sua definição enquanto unidade social particular. Deve-se, pois, levar 
em consideração as possiveis conseqüências para a interpretação do fenômeno - instância teórica do processo de investigação - que pressupõe, além da descrição e análise dos dados observados, a construção de um pensamento que explique uma dada realidade no contexto maior onde tem a sua expressão.

O estudo de cultura nas organizações enseja um debate interessante do ponto de vista teórico. Mais ainda quando se pretende aplicá-lo à investigação de organizações produtoras de serviços de saúde, tanto do setor público, quanto do setor privado de assistência à saúde. Caberiam algumas indagaçōes necessárias à continuidade desta reflexão: 0 que significa, em termos teóricos, a redução do conceito de cultura ao âmbito das organizações? O que significa delimitar a sua construção, durante o processo de pesquisa, dentro dos limites impostos por uma unidade organizacional produtora de serviços de saúde?

Primeiramente serão feitas considerações sobre o conceito de cultura organizacional para, em seguida, discuti-lo à luz do debate sobre organizações produtoras de serviços de saúde.

A noção de cultura organizacional implica na discussão de uma outra questão fundamental: a particularidade com que cada organização cria, sedimenta e expõe para fora de seus limites a sua essência. Ou seja, a noção desenvolvida por pesquisadores na área de administração acabou por produzir investigaçōes cuja finalidade seria a de identificar os elementos constitutivos da cultura própria de cada organização, desvendando seus aspectos essenciais e contribuindo para uma discussão mais aprofundada sobre o processo de mudança, ajustamento e, fundamentalmente, a busca de estabilidade.

Cabem algumas indagações pertinentes às afirmações feitas anteriormente: as realidades organizacionais constituem de fato particularidades culturais isoladas? A realidade das organizações encerra caracteristicas próprias, isto é, construídas em sua própria história, mas que 
constituiriam referências tão diversas que justificassem a noção ${ }^{13}$ de cultura organizacional? A noção de cultura organizacional, entendida enquanto sistema adaptador do indivíduo pressupõe uma realidade organizacional em busca de equilíbrio, da estabilidade, mas a constituição da própria estrutura da organização do trabalho não apontaria para uma outra perspectiva que é a do conflito permanente?

A abordagem antropológica veio contribuir para uma reflexão mais aprofundada sobre as organizações sem, contudo, tornar exclusiva a análise do ponto de vista do trabalho. Ou seja, uma análise exclusiva dos elementos componentes do processo de trabalho, que são as concepções que norteiam as definições sobre seu objeto, a força de trabalho cuja formação delimita a atuação na execução ou elaboração de idéias, e os meios necessários à execução das ações que promovam a transformação proposta no processo de intervenção. A importância destes elementos pode ganhar força em sua análise quando incorporados outros fenômenos não incluídos na análise do trabalho. Por exemplo, dentro das organizações é possivel apreender os processos de mudança e suas possiveis expressões através da resistência imposta pelos trabalhadores ou setores de uma organização, conflitos permanentes ou esporádicos, além de reações que possam comprometer 0 cumprimento das finalidades colocadas pela organização. $^{14}$

Para a antropologia, a dimensão do simbólico é concebida como aquela capaz de integrar todos os aspectos da prática social. 0 comportamento simbólico, portanto, implica na existência de estímulos fornecidos pelas significações produzidas na vida social e transformadas pela experiência. Ou seja, um plano da consciência com o qual reagimos aos símbolos produzidos na vida social.

\footnotetext{
${ }^{13}$ A idéia de noção, neste caso, antecede à de construção do conceito de cultura durante o desenvolvimento do processo de investigação. Portanto, o conceito está completo quando discutido em seus aspectos teóricos e, neste caso, especificamente, quando cotejado com as evidências empíricas levantadas durante o processo de pesquisa (Minayo, 1994).

${ }^{14}$ Cf. Fleury, M.T.L. \& Fischer, R.M.(coord.), Introdução do livro Cultura e Poder nas Organizaçסes, 1992.
} 
Segundo FLEURY $(1992)^{15}$, a postura do antropólogo vai diferir de outras abordagens sobre as organizações, tais como, pesquisa sobre clima organizacional ${ }^{16}$, justamente pelo questionamento produzido à respeito do significado do universo simbólico das organizações. Ao antropólogo caberia conhecer as concepçōes vigentes, as normas e os valores de uma dada organização, as quais são tomadas por certas mas permanecem obscurecidas no dia-a-dia. É fundamental, neste sentido, que estas concepçōes, normas e valores sejam comunicados, no cotidiano da vida organizacional, aos seus participantes. Tendo estes elementos por substrato na abordagem antropológica, pode-se localizar nos ritos (de passagem, de degradação, de confirmação, de reprodução, de redução, de conflito ou de integração), nos mitos, nas estórias cultivadas, ou mesmo no gestual comum utilizado na comunicação informal e até artefatos criados para cultivar aquele conjunto de símbolos, as características analíticas mais importantes em qualquer análise antropológica pretendida sobre organizações. (FLEURY, 1992: 19)

Nas suas origens, o conceito de cultura organizacional propôs um afastamento da análise comportamental, até então priorizada nos estudos organizacionais, enfocando a instância do individual como a mais importante para a compreensão da totalidade. Segundo SCHEIN (1991), ao afastar o conceito de cultura organizacional da instância individual, três perguntas que dizem respeito à sua reflexão devem ser feitas: porquê as organizações crescem? Porquê as organizações mudam? Porquê e como as organizaçōes acabam? $O$ autor nega a idéia de se elaborar estudos mais superficiais que capturem tão somente as eventualidades, ou seja, aquilo que é aparente. O conceito de cultura organizacional seria, então, especialmente relevante para entendermos os mistérios e os elementos constitutivos de uma realidade aparente, onde a irracionalidade das coisas é a primeira evidência. Sair da superfície e penetrar na essência de uma

\footnotetext{
${ }^{15}$ FLEURY, 1992, p. 19.

${ }_{16}$ Tipo de pesquisa que visa basicamente coletar informações que possam compor referências sobre opiniōes e percepçōes dos membros participantes de uma organização.
} 
dada realidade social, neste caso as organizações, significaria afirmar que a cultura deva ser observada nos níveis dos valores criados e recriados na organização e dos pressupostos básicos e pontos de vistas partilhados pelos seus membros, os quais, por sua vez, operam no nível inconsciente. (SCHEIN, 1991)

Outro conceito fundamental no entendimento desta proposta de análise organizacional, é o de mudança. Ou seja, a dinâmica das transformações produz mudanças constantes, sejam elas frutos de relaçōes externas ou mesmo internas da organização o que, segundo o autor, conduz os grupos internos à mobilização enquanto garantia de sua própria sobrevivência. Ao formular a idéia de que o movimento gerado pelas mudanças constantes, expressas nos arranjos internos ou até mesmo na manutenção das relaçōes já estabelecidas em dissonância com novas realidades, SCHEIN afirma que as organizações configuram-se como sistemas abertos em constante interação com o meio, permeadas por movimentos internos configurados por uma flutuação não tão facilmente previsivel pelo caráter inconstante que a mesma apresenta. Por exemplo, os sistemas abertos são formados por sub-grupos, unidades ocupacionais, hierarquias estabelecidas e, em alguns casos, apresentam-se dispersos geograficamente, o que significa entendê-los como particularidades que caminham no tempo, assumindo configurações próprias que acabam por definir traços específicos que impõem a diferença existente entre as organizações. (SCHEIN, 1991)

O fenômeno das organizações apresenta, dentro do esquema de interpretação proposto por SCHEIN, uma outra característica: a de se constituir enquanto uma unidade social particular. Com essa definição, tornam-se importantes as referências de sua história particular, recuperada, principalmente, através do levantamento e análise dos marcos históricos mais significativos, assim como em estudos que identifiquem as lideranças que influenciaram e ajudaram a formar a cultura de uma determinada unidade social. (SCHEIN, 1991) 
São necessários alguns comentários sobre os apontamentos teóricos desenvolvidos por SCHEIN. A idéia de unidade básica social pressupōe, no mínimo, um acordo tácito entre seus participantes de que a(s) finalidade(s) maior(es) da organização não só é compreendida como aceita por todos os membros componentes. Em última instância, as organizações caminhariam no sentido de equilibrar suas forças internas, as quais atuariam dentro das possibilidades de coesão, tendo por finalidade 0 cumprimento dos objetivos da organização. A questão, neste caso, não é somente a de incorporar a noção de mudança na análise, mas partir do suposto que há uma tendência, ou pelo menos uma necessidade contingencial, de equilibrar disparidades, afunilando-as num fluxo estabelecido previamente. Conhecer a cultura, portanto, significa saber agir através de constatações sobre a realidade do universo simbólico e, por isso mesmo, criar possibilidades de que ocorrências futuras, previamente incorporadas na direção do comando do processo sejam controladas.

O que é a cultura de uma unidade social particular senão os elementos simbólicos criados e recriados dentro de um contexto particular permeado de influências do universo social maior que the possibilita a existência? O que é a cultura organizacional produzida no contexto interno da organização através das relações estabelecidas entre grupos sociais distintos associados para uma ou mais finalidades e, por isso mesmo grupos diferenciados em seus pontos de vista, formas de relacionamento e, fundamentalmente, produtos e produtores de ideologias, entendidas como sistemas de idéias que organizam o pensamento e orientam a ação das pessoas em sua convivência social, também? Num certo sentido, há por detrás das concepçōes de SCHEIN um elemento estabelecido como fato: a orientação das organizações caminha na direção de compor um quadro de estabilidade. Para que isso ocorra, as lideranças, componente de análise fundamental na perspectiva de SCHEIN, devem necessariamente entender as especificidades das várias culturas existentes dentro de uma mesma organização como, por exemplo, a cultura gerencial, a cultura ocupacional, 
a cultura das unidades funcionais geográficas, a cultura dos grupos de trabalhadores, além da experiência vivenciada pelos membros da organização sobre as imposições de uma hierarquia.

Caberiam outros questionamentos sobre as afirmaçōes acima. A conformação apresentada por uma determinada organização se constrói dentro de seus limites, evidentemente. Mas sua totalidade não se esgota nestes elementos indicados anteriormente já que o próprio modelo que orienta e fornece sentido à existência das organizaçōes é construído historicamente, de acordo com uma formação interna, ou seja, um campo de conflitos encoberto por um manto de normas e diretrizes, outras vezes com seu interior abalado pelo acirramento dos conflitos inerentes, e, também, de acordo com as vicissitudes de uma dada realidade histórica concreta que impõe suas influências às unidades particulares.

Neste sentido, a idéia de consenso simbólico perde sua força de aplicação enquanto elemento teórico e, portanto, base de um quadro conceitual que dê sentido à pesquisa a medida que a coesão entre os grupos constitutivos de uma organização se diferenciam em vários aspectos, além de constituírem uma associação de grupos distintos com universos simbólicos compartilhados mas que distanciam-se justamente pela origem social diferenciada de seus membros e, por conseguinte, pela ocupação de postos específicos na hierarquia organizacional.

A idéia de conflito permanente parece mais adequada neste caso, o que remete ao problema da noção de cultura organizacional pensada enquanto conjunto de elementos particulares de uma dada organização. Pensar nessas particularidades parece ser uma necessidade para a própria organização repensar seus rumos, reestruturando o que considerar necessário, ou mantendo o que considerar adequado. Afirmação esta que não significa que as relações entre os membros, tomadas da perspectiva da instância do simbólico, se esgotem nas premissas básicas e nos valores cultivados pelas pessoas. É fundamental, portanto, estabelecer uma abordagem antropológica que privilegie, primeiramente, as condições de 
existência material de uma dada realidade, incorporando elementos fundamentais para a compreensão de qualquer realidade organizacional como, por exemplo, a finalidade de uma organização frente à sociedade e a hierarquia social presente nos limites da organização, além da organização do trabalho em seus aspectos sociais ou mesmo ocupacionais.

À análise das relaçōes simbólicas, enquanto elemento constituinte das relações sociais devem, pois, ser incorporadas as condições reais de existência material, as quais fornecem sentido a medida que indicam suas bases de existência; ou seja, suas referências concretas onde discursos, mensagens e representaçōes se consubstanciam enquanto essência das relações simbólicas, não separando-as portanto numa instância isolada cuja análise separada bastaria à interpretação da realidade das relaçōes sociais. (BORDIEU, 1992) ${ }^{17}$

É esta a base, portanto, do pensamento de BORDIEU, cuja noção de cultura não explica simplesmente um conjunto de códigos comuns, como um repertório comum de respostas de um determinado grupo de pessoas, mas como um "conjunto de esquemas fundamentais previamente assimilados, e a partir dos quais se articula, segundo uma 'arte da invenção' análoga à da escrita musical, uma infinidade de esquemas particulares diretamente aplicados a situações particulares" (BORDIEU,1992: 208-9). A cultura só existe na forma de símbolos, criando conjuntos de significantes e significados. É, na verdade, um sistema simbólico cuja bases repousam numa realidade primeira: as condições materiais de existência. ${ }^{18}$

\footnotetext{
${ }^{17}$ Cf. Bordieu, P. - Sistemas de Ensino e Sistemas de Pensamento, 1992. Neste artigo o autor discute o sistema de ensino enquanto componente essencial da integração cultural, tendo a instituição escolar como veículo organizado para estes fins.

${ }^{18}$ Esta noção de cultura não explica somente a diferenciação existente entre as classes sociais, entendidas enquanto categoria econômica de análise, mas também os campos de conflitos estabelecidos entre grupos sociais, tais como, grupos religiosos, associação civis ou mesmo pessoas formadas em instituições de ensino nas quais adquiriram esquemas específicos de interpretação do mundo.
} 


\section{Desdobramentos do conceito de cultura organizacional}

As considerações teóricas apontadas acima remetem a uma reflexão sobre o conceito de cultura e suas possibilidades enquanto instrumento teórico utilizado na interpretação das organizaçōes. Seu alcance tem uma relação direta com os elementos teóricos que o definem e fornecem sentido à sua aplicação. Desse ponto será retomado o conceito de cultura organizacional analisando-o à luz de outras referèncias teóricas para que, posteriormente, sejam acrescidos outros argumentos à discussão sobre suas bases teóricas.

A idéia de que uma organização produz dentro de seu processo histórico sua própria cultura, a qual modelaria as condutas e, mais do isso, forneceria sentido às ações dentro de uma prática social concreta, traduz na verdade a necessidade de se buscar compreender o sentido que liga as representações e outros simbolismos, como os ritos e os mitos, à ação dos membros de qualquer organização. O raciocínio explicita, portanto, uma efetiva aplicação da abordagem antropológica enquanto possibilidade de apreender as organizações além da abordagem sobre o processo de trabalho e todas as relaçōes sociais (politicas e simbólicas) que emanam das relações de trabalho.

Se, para SCHEIN, os valores esposados originam respostas aos membros de uma organização, conduzindo-os a comportamentos específicos que, no decorrer do tempo, tornam-se pressupostos que são as formas concretas de internalização de uma ou mais verdades, ou seja, passam do nível do consciente para o inquestionável ao serem incorporadas (FREITAS, 1991: 12), por outro lado, uma nova abordagem veio somar forças às suas idéias a partir da politização do conceito de cultura.

Segundo FLEURY(a) (1992), a cultura organizacional revela, além do tecido simbólico que entrelaça seus membros, as relações de poder constituidas e que fundamentam tanto a administração formal quanto a informal. A mediação das relações, seja entre os postos da hierarquia, seja entre os membros de um mesmo nível hierárquico, são sustentadas por 
comportamentos e símbolos mas, fundamentalmente, por valores e idéias que vão formando uma identidade própria. Uma "identidade compartilhada pelos empregados nos diversos níveis hierárquicos" FLEURY $\left._{(\mathrm{b})}, 1992\right)$. Vejamos no trecho transcrito a seguir as considerações da autora sobre a noção de identidade ${ }^{19}$.

"Ao penetrarmos no cotidiano das relações sociais da empresa (uma empresa agro-industrial açucareira), um aspecto que nos chamou a atenção foi o da existência de uma identidade organizacional, identidade esta compartilhada pelos empregados nos diversos niveis hierárquicos. Ao lado de comportamentos e símbolos bastante visiveis como uniforme, refeitórios comuns aos empregados, tratamento informal entre chefes $e$ subordinados, percebiamos a existência de valores, idéias, tecendo esta identidade, mediando as relaçōes de trabalho." (FLEURY(b), 1992: 113-4)

A proposta teórica da autora é a de apreender as relações de trabalho em suas várias instâncias definidoras, a saber: a política (relações com o Estado; movimentos sociais); a institucional legal; organização do processo de trabalho; e, a politica de recursos humanos. A estas instâncias foi acrescida a identidade organizacional não como elemento de análise separado da totalidade da organização, mas como um aspecto importante para se compreender realidades organizacionais complexas, caracterizando de forma mais abrangente o trabalho.

Há, portanto, a construção de um novo modelo teórico incorporador da instância do simbólico, politizando a própria definição de cultura e definindo-a como:

"conjunto de valores e pressupostos básicos, expressos em elementos simbólicos, os quais, em sua capacidade de ordenar, atribuir significaçōes, construir a identidade organizacional, tanto agem como elementos de comunicação e consenso, como ocultam e

${ }^{19}$ Sobre o conceito de identidade cf. Bassit, A.Z.(org.), Identidade: Teoria e Pesquisa, 1983. 
instrumentalizam as relações de dominação." (FLEURY(b), 1992: 117)

A autora amplia, neste sentido, as possibilidades de um entendimento mais próximo do campo de conflitos estruturado, além de apresentar as relações sociais como tendo sido construidas dentro de uma história particular, própria de cada organização. Sua proposta é a de construir uma biografia organizacional, resgatando a história particular e orientando o estudo para o desvendar das relações de poder e toda a produção simbólica própria de cada organização, como forma de compreender sua identidade. (FLEURY(b), 1992)

Ao cuidar da dimensão simbólica enquanto elemento chave no entendimento e intervenção na realidade social, parecem ser necessárias algumas considerações sobre os postulados teóricos do que se convencionou denominar de interacionismo simbólico (BERGER, 1997; GOFFMAN, 1992), cuja proposta de resgate da identidade de um grupo populacional, ou uma organização, poderia ser feito a partir de uma descrição da vida cotidiana.

Segundo BERGER:

"(...) Se quisermos entender a realidade da vida cotidiana é preciso levar em conta seu caráter intrinseco antes de continuarmos com a análise sociológica propriamente dita. A vida cotidiana apresenta-se como uma realidade interpretada pelos homens e subjetivamente dotada de sentido para eles na medida em que forma um mundo coerente. (...) O mundo da vida cotidiana não somente é tomado como uma realidade certa pelos membros ordinários da sociedade na conduta subjetivamente dotada de sentido que imprimem a suas vidas, mas é um mundo que se origina no pensamento e na ação dos homens comuns, sendo afirmado como real por eles. Antes, portanto, de empreendermos nossa principal tarefa devemos tentar esclarecer os fundamentos do conhecimento na vida cotidiana, a saber, as objetivações dos processos (e significações) subjetivos graças às quais é construido o mundo inter-subjetivo do senso comum." (BERGER, 1997: 35-6) 
E mais:

"A realidade social da vida cotidiana é portanto apreendida num contínuo de tipificaçōes, que se vão tornando progressivamente anônimas à medida que se distanciam do 'aqui e agora' da situação face a face. Em um pólo do contínuo estão aqueles com os quais freqüente $e$ intensamente entro em ação recíproca em situações face a face, meu 'círculo interior', por assim dizer. No outro polo estão abstraçōes inteiramente anônimas, que por sua própria natureza não podem nunca ser achadas em uma interação face a face. A estrutura social é a soma dessas tipificações e dos padrōes recorrentes de interação estabelecidos por meio delas. Assim sendo, a estrutura social é um elemento essencial da realidade da vida cotidiana." (BERGER, 1997: 52)

Ao imaginar portanto a dimensão simbólica como campo privilegiado de observação, porque integrador de todos os aspectos da vida social, caberiam alguns questionamentos sobre o entendimento do conflito dentro das organizações. Segundo BORDIEU (1985), a visão "subjetivista" proposta pelo interacionismo incorre no risco de reduzir o mundo social às representações que dele fazem os agentes, o que implica, neste caso, na tarefa das ciências sociais produzirem uma explicação das explicações (account of the accounts) produzidas pelos sujeitos sociais. (BORDIEU, 1985:150)

Estaria no senso comum portanto a base para se pensar a realidade social, segundo o interacionismo, cabendo ao cientista social construir um conhecimento que seja uma continuidade do senso comum. Construçōes das construçōes, ou construçōes de segundo grau. Cabe a pergunta: como captar as relações somente através da observação? Como é possivel a apreensão concreta dessas relaçōes sociais, objetivas e irredutiveis às interações que se manifestam?

$\dot{A}$ afirmação do interacionismo de que a estrutura social consiste no conjunto de tipificações produzidas no senso comum, captadas e 
interpretadas pelos cientistas sociais, perde-se, pela perspectiva teórica indicada por BORDIEU (1985) a possibilidade de se entender os agentes sociais como estando distribuídos no espaço social global. O espaço social, por sua vez, "está construído de tal modo que os agentes que ocupam posições semelhantes, ou vizinhos que estejam colocados em posições semelhantes, e têm toda possibilidade de possuirem disposições e interesses semelhantes, "acabam por produzir práticas também semelhantes" (BORDIEU, 1985: 154-5). A questão portanto é a de entender - campo de relações sociais a partir de disposições diferenciadas assumidas pelos agentes sociais. E são essas disposições adquiridas, que o autor denomina de interações, que promovem o ajustamento social, onde podem ser encontradas distâncias sociais não só do ponto de vista das percepções que os individuos produzem sobre sua vida, como da sua inserção e atuação na vida social.

Neste sentido, as representações dos individuos vão variar segundo suas posições sociais e os interesses a elas associadas, assim como os agentes podem variar segundo seu habitus, ou seja, o sistema de esquemas de produção de práticas e um sistema de esquemas de percepções no qual está inserido e que ajudou a construir ${ }^{20}$. Vejamos a seguinte passagem:

"O habitus (...) faz com que o mundo social não se apresente como um puro caos, totalmente desprovido de necessidade e possível de ser construído não importa como. Mas esse mundo também não se apresenta como totalmente estruturado e capaz de impor a todo sujeito perceptivo os princípios de sua própria construção. 0 mundo social pode ser dito ou construído de diferentes maneiras de acordo com diferentes princípios de visão e divisão." (BORDIEU, 1985: 160)

\footnotetext{
${ }^{20}$ Sobre a noção de habitus, cf., também, Bordieu, 1992(b).
} 


\section{A cultura: relações simbólicas, relações sociais}

Entendendo, portanto, a dimensão simbólica como capaz de integrar todos os aspectos da prática social, o interacionismo impōe algumas restrições quanto ao entendimento da dimensão do conflito nas organizaçōes. Caberiam duas perguntas sobre este aspecto: no sentido inverso da interação social, expressões simbólicas de resistência não estariam presentes numa organizaçāo enquanto resultado do campo de conflitos e este, por sua vez, não consistiria em uma gama de relações sociais constituídas por uma hierarquia social construida à revelia da percepção imediata dos sujeitos? A dimensão simbólica ao ser capaz de integrar "todos os aspectos da vida social" (FLEURY(a), 1992: 17) não estaria melhor dimensionada através da noção de ideologia enquanto conceito mais adequado para se entender as relações estabelecidas numa organização?

O debate sobre os conceitos de cultura e ideologia é desenvolvido por DURHAN (1984), cujas preocupaçōes teóricas com relação às duas noçōes leva a autora a expor a seguinte argumentação: "os fenômenos ideológicos dizem respeito ao universo simbólico e possuem uma afinidade básica com os mitos, questōes estas às quais a antropologia tem dedicado o melhor de seus esforços" (DURHAN, 1984: 71). A proposta é a de que deve ser percebida uma permeabilidade entre os dois tipos de abordagem - da cultura e da ideologia, ao mesmo tempo que haja a preservação dos recursos de análise de uma e de outra.

Assim, o conceito de cultura possibilita a busca da generalidade existente nas sociedades, tornando-se cada vez mais complexa a sua adequação ao estudo das sociedades fragmentadas em sua produção simbólica, enquanto que o conceito de ideologia se constitui enquanto instrumento de análise referente a modos específicos de dominação e a modos específicos de produção de conhecimentos que são próprios de cada sociedade capitalista. Neste sentido, a autora retoma a questão entre o 
sujeito da ação e suas condições reais de existência, afirmando que a antropologia tem o potencial de unir os dois elementos, enquanto que a noção de ideologia coloca-as em instâncias separadas, diferenciadas pela oposição entre representação-realidade, dadas as diferenças entre as práticas ideológicas (superestrutura) e as práticas produtivas (infraestrutura). (DURHAN, 1984: 86)

A esta separação apontada pela autora é oferecida a seguinte perspectiva teórica:

"O que estamos tentando defender aqui é a preservação do conceito de cultura, como instrumento para analisar a questão do simbolismo e da significação na ação humana, não como prática específica mas como elemento constituinte de todas as práticas, igualmente relevante na produção material e no debate escolástico. Sem negar a importância da distinção entre infra-estrutura e superestrutura, recusar a identificação dessas instâncias com práticas sociais especificas. Manter a concepção antropológica de que as práticas sociais são sempre sinteses de múltiplas determinações e sempre, necessariamente, também simbólicas, isto é dotadas de significação." (DURHAN, 1984: 81)

Tal perspectiva conduz a pensar o conceito de cultura como garantia da idéia de que o mesmo cuidará de um todo simbólico sem contudo perder o conteúdo político inerente à ideologia.

Essa reflexão exposta anteriormente está estruturada sob a idéia de se analisar sociedades contemporâneas, possibilitando inclusive 0 estabelecimento de comparaçōes com outros tipos de sociedades. 0 importante, neste caso, é a incorporação da dimensão política no debate sobre a cultura nas sociedades divididas em classes sociais. Esta, por sua vez, entendida através da análise das práticas sociais concretas e das representaçōes formuladas por grupos ou categorias sociais, sendo sua relevância política só determinada a posteriori.

Neste sentido, politizar a abordagem antropológica é caracterizar a forma como os sistemas simbólicos se transformam em prática política. A 
idéia de identidade coletiva encerra a argumentação de DURHAN (1984) e indica como grupos, segmentos e categorias constróem e utilizam referenciais simbólicos que thes permitam definir seus interesses específicos. As diferenças marcam o início da identificação das relações políticas entre os sujeitos da ação. Sujeitos políticos porque defensores de perspectivas diferenciadas de entender e agir socialmente. ${ }^{21}$

A noção de unidade social particular, encontrada no trabalho de SCHEIN (1991) e retomada por FLEURY(a) (1992), é acrescida da idéia de politização da noção de cultura. A particularidade histórica, ao gerar novos elementos culturais que explicam somente a sua própria história, é composta de sujeitos políticos que vivenciam sua própria biografia, tanto no âmbito da vida privada como, fundamentalmente, neste caso, no âmbito das relações de trabalho. A particularidade cria novos simbolismos e significaçōes próprias de cada organização, sem contudo recriar a própria experiência social vivida por uma unidade básica social.

A superfície do aparente não demonstra de fato como a intimidade de uma organização se estrutura, gerando símbolos e significados como expressão das relações sociais existentes, as quais, por sua vez, geram práticas especificas. A abordagem antropológica pode, sim, levantar as representaçōes produzidas no espaço de uma organização, tomando por particular o que é expressão de uma complexa trama trespassada de símbolos e significados de classes, grupos e categorias, analisando-a em sua principal caracteristica: pertencer a uma sociedade dividida em grupos sociais e, por isso mesmo, constituir talvez particularidades mais pelos vínculos com o ambiente social do que pela sua história interna.

${ }^{21}$ Cf. Gramsci, A., Concepçáo Dialética da História, 1984. 


\section{A construção do conceito de cultura organizacional}

A abordagem antropológica se justifica, nesta pesquisa, enquanto possibilidade de recuperar a formação, o sentido - passado e presente, as relaçōes inter-institucionais e, fundamentalmente, a trama das relaçōes sociais dentro da organização, o que pressupōe entendê-las como um conjunto de práticas associadas a finalidades distintas. Neste caso, a assistência, o ensino e a pesquisa integrados, aos quais são atribuidos significados distintos e, portanto, valorizados de forma diferenciada pelos membros componentes da organização.

As organizações de saúde que também se ocupam do ensino têm suas particularidades, fato que as distingue das outras. Por exemplo, as relações internas são acrescidas da participação de pessoal docente das escolas que as subordinam, o que implicaria em afirmar que a organização interna da produção de serviços atende à demanda do ensino e também de pesquisa, estabelecendo relações complementares que acabam, muitas vezes, por se confrontar em disputas institucionais que objetivam resguardar espaços dentro da própria unidade, criando uma fragmentação interna à organização.

Há, portanto, uma especificidade orientada pela própria finalidade que estas unidades de saúde e ensino propõem. A complexidade destas unidades reside antes na composição dos recursos humanos que se apresentam como um leque de formações distintas e associadas na produção da assistência. Portanto, é ai que reside a sua especificidade: a qualidade de prestar os serviços de ensino e, também, produzir pesquisa, conferindo uma distinção quanto às outras unidades.

Tomada como premissa a idéia de que o universo simbólico e de significação de uma unidade de saúde e ensino seja constituido a partir da composição social existente, que se apresenta como um leque de diferenças entre os membros componentes - diferenças essas que têm origem no posicionamento que cada agente ocupa na sociedade (BORDIEU, 1992), além das diferenças estabelecidas pelo nivel de 
formação escolar e mesmo universitária dentro de cada unidade, ocorre que a idéia de fragmentação desse universo simbólico e de significações distintas em cada agente seria adequada à compreensão do fenômeno, identificando os elementos de conflito e, também, os de justaposição criados no espaço da organização.

A idéia de conflito permanente cabe com maior precisão, neste caso, dada as condiçōes de contato social proporcionadas pela organização e, também, pelas atividades concomitantes de ensino que imprimem um caráter diferenciado porque realizador de uma outra prestação de serviço, a outra clientela.

Esta expressão de significados que compõem um quadro de relaçōes concretas, tem por referência menos um universo particular de produção dos significados e relações sociais, do que uma composição de expressões que são fruto dos arranjos e rearranjos das finalidades impostas pela organização, associadas à composição social dos agentes envolvidos que, por sua vez, estariam associadas à problemática da diferenciação sócio-cultural dos membros da unidade e, fundamentalmente, a participação $e$ as novas necessidades impostas na mudança do perfil da clientela enquanto agente beneficiado pela produção de serviços e agente que beneficia as atividades de ensino.

Ao criar a imagem de uma cultura particular tendo por referência os elementos diferenciadores apontados acima, é necessário um cuidado especial para não ocasionar um desprezo à riqueza dos significados construidos dentro da organização pela prática social dos agentes de saúde inseridos, tomando como elemento de análise somente a produção de serviços. A particularidade se expressa através da forma como as relaçōes se estabelecem por finalidade ao cumprimento dos objetivos da organização. Saber captar os fragmentos e ordená-los em seus significados, acaba por conferir a necessidade de se trazer à tona o modelo de trabalho desenvolvido pela organização, o qual concebe tanto a realidade interior e a exterior à organização, como estabelece a ordenação do processo de 
trabalho a partir deste. Tendo estes elementos por referência é possivel escapar de um vazio simbólico cuja ausência de significados ocorre justamente pelo distanciamento das relações concretas estabelecidas através e sobre a forma ideal preconizada pela organizaçăo.

Neste sentido, o movimento de interação entre a organização que produz serviços de saúde, ensino e pesquisa, e a população que a utiliza e é beneficiada pelas suas ações, constitui o foco de atenção principal deste estudo. As mudanças ocorridas no perfil populacional, trazendo novos segmentos sociais para serem assistidos na unidade como, por exemplo, imigrantes coreanos e bolivianos, população moradora de rua e trabalhadoras do sexo ${ }^{22}$, imprimiu uma série de mudanças internas, ou seja, da definição de novos programas de assistência, de mudanças no fluxo dos pacientes e do deslocamento de recursos materiais e funcionários necessários e, também, em termos da percepção que os agentes de saúde passaram a desenvolver dessa nova realidade.

Compreender os significados presentes na unidade sobre as suas finalidades com relação à população assistida, aos alunos, ou aos pesquisadores que têm suas temáticas voltadas para o nivel de atenção primária, implica num primeiro momento definir a própria noçăo de organização enquanto unidade destacada do contexto maior.

A noção de organização, aqui entendida como o conjunto de recursos materiais e o agrupamento de profissionais com a finalidade de cumprir as atividades de proteção e promoção à saúde da população, além do ensino, torna-se complexa quando pensada em sua dimensão educacional. O suporte oferecido para as atividades de ensino, assim como as de pesquisa, constituem elementos fundamentais no entendimento da organização.

Entendida pelo contexto maior no qual está inserida, a organização é um microcosmo que representa, em sua essência, o domínio

\footnotetext{
${ }^{22}$ O termo trabalhadoras do sexo é a única designação utilizada por qualquer um dos funcionários que queiram fazer qualquer referência aos trabalhos de assistência e pesquisa desenvolvidos junto às prostitutas que atuam na área central da cidade.
} 
de um objeto institucional (Albuquerque, 1978) com exclusividade. Neste caso, a particularidade da forma como a organização se apresenta conta, além da inclusão das atividades de ensino e pesquisa, com o fato de ter sido concebida e executada por um grupo de professores representantes de uma escola médica.

As concepções presentes e representadas por estes professores incluía tanto as transformações que marcaram a organização do sistema público de saúde no estado de São Paulo e no Brasil, assim com as idéias que transpunham as fronteiras entre os paises do continente americano, como as noçōes de medicina integral e comunitária. Este contexto maior influenciou e, portanto, imprimiu suas marcas numa organização que atravessou três décadas de existência e que permanece até os dias de hoje atuando na área central da cidade de São Paulo.

Pensar, portanto, na construção do conceito de cultura organizacional é pensar, primeiramente, neste contexto maior que imprimiu suas marcas e criou um modelo cujas particularidades esta pesquisa pretende demonstrar. Num segundo momento, a investigação das concepções presentes entre os agentes de saúde demonstrará os valores presentes nas interpretações que fazem sobre sua atuação no trabalho e o contexto maior que o cerca. 


\section{CAPITULO 2 - METODOLOGIA DE PESQUISA}

Ao promover os primeiros contatos tendo por finalidade a elaboração do projeto de pesquisa, teve início um movimento de aproximação com a prática cotidiana das pessoas envolvidas nos trabalhos realizados no Centro de Saúde-Escola Barra Funda. É nesse momento da pesquisa que os conceitos esboçados anteriormente passam a constituir referências em nosso pensamento, fornecendo as orientaçōes necessárias à construção de idéias que expliquem as evidências observadas.

Não se trata, evidentemente, de aplicar um modelo teórico à realidade, mas antes de torná-lo parte do caminho a ser percorrido das evidências concretas às abstrações teóricas. Neste caso, a noção de cultura organizacional passa a ganhar substância à medida que algumas evidências levantadas na exploração promovida no campo de pesquisa começam a fornecer sentido às abstrações definidas anteriormente.

No caso especifico desta pesquisa, cujas bases teóricas estão assentadas nos estudos qualitativos, a delimitação do objeto de investigação sofre transformações no decorrer do processo de pesquisa pois, à medida em que o desenvolvimento da coleta de dados vai proporcionando o levantamento de evidências empíricas não detectadas durante a fase de elaboração do projeto de pesquisa, a reflexão sobre o objeto vai assumindo novas configurações. São colocadas, portanto, neste processo, novas possibilidades de se pensar o objeto real de investigação simultaneamente ao esforço de estar constantemente questionando o objeto teórico esboçado anteriormente. Este movimento pode ser exemplificado pelo posicionamento e pelos niveis de participação assumidos por determinadas categorias profissionais na rede interna de relações, ou mesmo pelas diferenças apreendidas no contato direto com as pessoas sobre as suas concepções com relação à trajetória profissional, suas atividades de trabalho atuais, seu envolvimento com a pesquisa e o ensino 
e suas concepções sobre a clientela que freqüenta a unidade de saúde.

A diversidade de pontos de vista coletados durante os contatos na fase de campo de pesquisa acabaram por gerar um conflito entre o pólo teórico e as referências concretas observadas, o que possibilitou viabilizar um campo de reflexões, dentro do qual nosso pensamento se constitui e caminha em busca de explicar as relações sociais desenvolvidas naquele contexto.

A metodologia de pesquisa, tomada enquanto caminho a ser percorrido entre a teoria e a realidade estudadas, procura demarcar, primeiramente, os limites de separação entre a ciência e outras formas de apreender a realidade. Segundo DEMO (1995), a metodologia nas Ciências Sociais deve ser entendida tanto em seus aspectos mais práticos, ao estudar os caminhos percorridos no processo de pesquisa e dos instrumentos utilizados na pesquisa, como também deve problematizar criticamente o fazer ciência, já que pode viabilizar a indagação sobre os seus limites, sua capacidade de produzir conhecimento $e$, também, sua capacidade de intervir na realidade. A transcrição a seguir apresentada é ilustrativa sobre este aspecto:

"Metodologia distingue-se em nosso meio de Métodos e Técnicas, por estar em jogo no segundo caso o trato da realidade empírica enquanto no primeiro existe a intenção da discussão problematizante, a começar pela repulsa em aceitar que a realidade social se reduza à face empírica. Não se trata de rebaixar Métodos e Técnicas a atividade secundária. Para o trato da face empírica são essenciais. Metodologia adquire o nivel de típica discussão teórica, inquirindo criticamente sobre as maneiras de se fazer ciência. Sendo algo experimental, dos meios, não tem propriamente utilidade prática direta, mas é fundamental para a 'utilidade' da produção científica. A falta de preocupação metodológica leva à mediocridade fatal." (DEMO, 1995: 12)

A distância a ser percorrida entre as construções teóricas e um possivel objeto empírico delimitado previamente requer um constante 
movimento de crítica no pensar. Ou seja, os questionamentos são necessários e devem sempre estar presentes no processo de pesquisa, garantindo a criatividade necessária à produção do conhecimento científico. No caso desta investigação, a construção dos caminhos a serem percorridos identificando a qualidade das evidências empiricas e seus possiveis desdobramentos teóricos. Não se trata portanto de criar posturas rigidas, mas antes de criticá-las em seu processo de construção. Numa palavra: os conceitos devem ser constantemente questionados durante a investigação e a sua construção decorre justamente desta crítica que viabiliza, a partir da demonstração do processo, a exposição dos caminhos tomados evitando as generalizações apressadas à medida que ordena e sistematiza a produção do conhecimento. As referências teóricas viabilizam a construção de nosso pensamento à medida que definem os parâmetros que direcionam a investigação, circunstanciando os limites do objeto de investigação.

Caberia, neste caso, a complexa e instigante pergunta: qual é o substrato da cultura organizacional? Pergunta que seria respondida, ainda de forma preliminar, indicando as mais variadas manifestações internas às organizaçōes, as quais fazem parte de sua história como também compõem os elementos integrantes da prática cotidiana, fornecendo sentido às pessoas inseridas em seus limites. Ritos (de inserção, de passagem), mitos (heróis institucionais, passado revivido), mudanças na esfera do trabalho assim como da própria realidade social à qual o serviço de saúde se dedica, ou mesmo formas de expressão particulares assumidas na organização são alguns dos elementos constituintes a serem investigados.

Ao percorrer, portanto, o caminho de ida às evidências empíricas, devidamente orientados pelos referenciais teóricos que delimitam a trajetória e o dimensionamento das técnicas de pesquisa a serem empregadas, é possível distinguir o tipo de conhecimento desejado. Este debate abre a discussão sobre as distinções entre os niveis de compreensão da realidade, à qual DEMO (1995) indica três níveis distintos: 
o científico, delimitado pelo pensamento racionalizado, que busca objetivar o conhecimento através da postura critica em relação aos elementos teóricos e práticos dentro do processo de pesquisa; a ideologia, definida como sendo um conjunto de idéias de caráter justificador do posicionamento social vantajoso se tomado em relação a outros grupos sociais; e, por fim, o senso comum, cujas características de acriticidade, imediatismo e credulidade conduzem à formulação de um pensamento fragmentado sobre a realidade (DEMO, 1995: 18). Evidentemente que nāo há limites rígidos entre os conceitos expostos acima, mas se tomados como elementos promovedores de um debate que exponha o caráter crítico assumido por um determinado posicionamento na produção do conhecimento científico, tornase necessária a exposição dos limites que afastam a ciência dos outros dois conceitos.

A noção de ruptura epistemológica ${ }^{1}$, neste sentido, pode ser compreendida como um momento crítico essencial à pesquisa, momento em que é possivel promover o deslocamento dos niveis do senso comum ou ideológico. Parte-se do princípio de que o objeto científico é construído, confirmando a existência de uma temporalidade dentro do processo de produção do conhecimento, a qual deve reconhecer o caráter histórico e transitório deste conhecimento. Há uma contraposição, portanto, entre um objeto pré-construído pela percepção do investigador e um objeto constantemente repensado e, por isso mesmo, construído dentro de uma série de reflexões que vão promovendo o rompimento com aquelas percepções iniciais. À espontaneidade das percepções iniciais sobrepõe-se a busca da objetividade, a qual por sua vez procura esclarecer "de maneira especifica a relação da qualidade de um objeto psíquico com sua estruturação como objeto de ciência". (DE BRUYNE, 1982: 51)

Há duas definições fundamentais sobre este aspecto: por um lado, a noção de objeto percebido, a qual cria imagens sobre a realidade através de nossos sentidos, aproximando-nos do real através da

\footnotetext{
${ }^{1}$ Sobre o conceito de ruptura epistemológica, cf. De Bruyne et al., Dinâmica de Pesquisa em
} 
experiência sensível. No caso desta pesquisa, a aproximação inicial deveuse à percepção da existência de uma sensibilidade presente na rede de relações sociais interna. Num primeiro momento foi pensada como principal razão o fato de ser um Centro de Saúde-Escola experimental em suas origens, o que indicaria uma qualidade diferencial: voltar suas atenções a segmentos da população pela sua própria capacidade de atuar como um laboratório onde seriam produzidos novos conhecimentos no campo das práticas em saúde.

Por outro lado, o objeto do conhecimento, que consiste num "sistema simbólico que difere em natureza do objeto real e em sua complexidade do objeto científico através de procedimentos metódicos de construção do conhecimento (DE BRUYNE, 1982: 52). Neste caso, a base teórica estruturada a partir da noção de cultura organizacional, cujo escopo pode ser definido como a busca das particularidades construídas na história organizacional, explicariam as formas de organização inicial, a qual se manteria enquanto tendência para estas novas ocorrências.

O sentido de aproximação do real estaria implícito nesta conceitualização que difere os objetos entre o percebido e o do conhecimento. Temos, portanto, que ao estabelecermos os critérios que delimitam qualquer investigação, desde a definição do tema, passando pelos recortes dos fatos até a coleta de informações, acabamos por construir um conhecimento possivel, tornando-o uma operação com sentidos próprios, mas objetivada pelo rompimento proporcionado no momento da ruptura quando pré-noções e preconceitos são abandonados, provocando um afastamento das percepções iniciais. "Esta ruptura só pode ser efetuada a partir de uma representação teórica prévia, que seja suscetivel de exprimir a lógica que o investigador supõe estar na base do fenômeno" (QUIVY \& CAMPENHOUDT, 1992: 25)²

Ciências Sociais, 1982.

${ }^{2}$ É particularmente interessante a obra de Quivy, R. \& Campenhoudt, L.C. Manual de Investigação em Ciências Sociais, 1992, no tocante aos procedimentos de pesquisa. As noções de ruptura, construção e verificação são expostas na seqüência do processo de pesquisa, elucidando as fases desde as pré-noções, fundamentais no desencadear do próprio processo, até as construções teóricas 


\section{Limites e possibilidades de um estudo qualitativo}

A temática que sustenta este trabalho de investigação supõe a busca do significado atribuido por agentes sociais posicionados em uma unidade básica de saúde. Agentes sociais que ocupam posições distintas, tanto administrativas, quanto sociais, formando uma rede de relaçōes internas mediadas pelas três finalidades de um Centro de Saúde-Escola: a assistência, o ensino e a pesquisa. Os significados produzidos internamente indicam que além da prática do trabalho, referenciado nas formações específicas de cada profissional, estão em jogo referências próprias dos grupos sociais aos quais pertencem estes agentes. Há, portanto, que se considerar outros aspectos da vida social que impõem à rede interna de relaçōes significados muitas vezes fundamentados em práticas até mesmo externas ao próprio trabalho. A qualidade que se atribui ao trabalho, seja para qualquer uma das três finalidades que justificam a organização (assistência, ensino e pesquisa) no Centro de Saúde-Escola, implica necessariamente na busca de uma gama variada de elementos constituintes das representações ${ }^{3}$ elaboradas pelos agentes de saúde investigados.

Ao delimitar os elementos a serem observados na dinámica interna à organização (o trabalho, o suporte administrativo, as concepções das categorias profissionais envolvidas, fatos mais marcantes de sua história), ficariam definidos os limites que fornecem orientação à pesquisa.

Quanto às reflexōes sobre os procedimentos de pesquisa, estes devem constituir um corpo sólido de idéias já que a própria dinâmica de observação implica na mobilização dos sujeitos investigados. Por exemplo, a situação de entrevista, recurso técnico utilizado na pesquisa e comentado à frente, é um momento de reflexão para o entrevistado. Momento que suscita um movimento interior dos agentes sociais em busca de respostas para questionamentos nem sempre pensados no cotidiano do trabalho. 0 estudo qualitativo configura-se, portanto, como uma abordagem que

${ }^{3}$ Sobre o conceito de representações sociais, cf. Minayo, M.C.de S., O Conceito de Representações Sociais dentro da Sociologia Clássica, 1994. 
contempla um aprofundamento no significado da palavra daqueles que falam estimulados por um processo de intervenção. Este, por sua vez, é mediado por constructos mentais e técnicas de pesquisa que fundamentam o trabalho de investigação.

Algumas características da abordagem qualitativa são importantes de serem ressaltadas, tendo em vista apresentá-la não como recurso metodológico diverso ou até mesmo oposto à abordagem quantitativa, mas indicando-a como possivel de abrir caminhos até as respostas às indagações iniciais de pesquisa. $O$ objeto de pesquisa em foco requer, portanto, algumas diretrizes que contemplem a busca do significado na expressão dos agentes sociais que falam de seu trabalho, seu cotidiano, seu envolvimento com a população assistida pelo Centro de Saúde-Escola, enfim, daqueles que expõem seus pensamentos, construindo um raciocínio que flui conforme os elementos objetivados no processo de pesquisa.

Uma primeira caracteristica importante nos estudos qualitativos é a situação do campo de pesquisa enquanto fonte direta das informações a serem levantadas. O pesquisador, neste caso, é o principal instrumento ${ }^{4}$, tendo o ambiente natural, ou seja, o locus onde os acontecimentos se desenrolam, como posto de observação. O trabalho de campo é uma prática intensiva, esperando do pesquisador um contato direto e prolongado que the proporcionará uma influência dos contextos onde ocorrem, os fenômenos estudados. Referências a pessoas, gestos e palavras são ações que trazem significados importantes de serem apreendidos. A descrição minuciosa dos dados é outro aspecto essencial. Citaçōes literais, histórias narradas, comentários, etc., constituem os elementos procurados pelo pesquisador.

Assim, o pesquisador deverá reter, através da perspectiva dos observados, os diferentes enfoques que os mesmos estabelecem sobre as suas relações diárias e a compreensão deste conjunto de intrepretações

\footnotetext{
${ }^{4}$ Sobre pesquisa qualitativa, cf. Chizzotti, A., Pesquisa em Ciências Humanas e Sociais, 1995. Haguette, T.M.F., Metodologias Qualitativas em Sociologia. 1995; Lüdke, M. \& André, M.D.A., Pesquisa em Educação - Abordagens Qualitativas, 1986; Minayo, M.C.de S., O Desafio do Conhecimento - Pesquisa Social em Saúde, 1992; Triviños, A.S.S., Introdução à Pesquisa em Ciências Sociais - a Pesquisa Qualitativa em Educação, 1995.
} 
realizadas no processo de pesquisa deve ser constantemente checada com os participantes. ${ }^{5}$ São necessários, portanto, uma atenção especial para as rápidas decisões que às vezes devem ser tomadas e para a constante atenção do pesquisador voltada para aspectos triviais ou para acontecimentos mais importantes que possam ser registrados e, posteriormente, analisados.

Por fim, a análise dos dados tende a seguir um processo de raciocínio que vai do particular ao geral. ${ }^{6}$ Não há busca de evidências empíricas cuja finalidade seja comprovar hipóteses estabelecidas a priori. 0 que se espera é um constante inspecionar os dados cabendo ao pesquisador criar reflexōes que partam deste concreto, indo até a formulação de abstrações referendadas em quadros teóricos. As diretrizes, dentro do processo de pesquisa, são estabelecidas anteriormente por pressupostos ${ }^{7}$, as quais vão sendo transformadas de questões amplas em reflexōes mais diretas e específicas sobre os dados coletados, podendo o pesquisador formular idéias que 0 aproximem de uma interpretação pormenorizada da realidade investigada.

A essência da pesquisa qualitativa está na sua capacidade de formulação de descrições minuciosas da realidade social. Os detalhes identificados em campo devem ser descritos com o rigor de quem tece um emaranhado de consideraçōes, estabelecendo a lógica que funda determinadas relações sociais. A atitude de constantemente explorar 0 campo conduz às decisōes sobre os rumos da pesquisa gerando, assim,

\footnotetext{
${ }^{5}$ Cf. Lüdke \& André, 1986.

${ }^{6}$ Idem.

${ }^{7}$ A noção de hipótese é discutida por Minayo, M.C. de S. na obra O Desafio do Conhecimento Pesquisa Social em Saúde, 1992. A seguinte passagem é elucidativa quanto ao termo em questão: "O próprio termo 'hipótese' possui uma conotação positivista que crê na possibilidade do conhecimento objetivo da realidade e nas provas estatístico-matemáticas como comprovadoras da objetividade. Hoje tanto o marxismo como a fenomenologia, embora incorporem o conceito de 'hipótese', o reinterpretam e o problematizam. $\mathrm{Na}$ abordagem qualitativa, as 'hipóteses' perdem sua dinâmica formal comprobatória para servir de caminho e de baliza no confronto com a realidade empírica. Costuma-se até usar o termo pressupostos para falar de alguns parâmetros básicos que permitem encaminhar a investigação empirica qualitativa, substituindo assim o termo hipótese com conotações muito formais da abordagem quantitativa." (MINAYO, 1992: 95)

Os grifos e as aspas são da autora.
} 
novos conhecimentos à medida que o caráter flexivel da postura do investigador consubstancie uma gama de procedimentos que garantirão um trabalho abrangente e consistente em suas análises.

São esses, basicamente, os procedimentos que ordenam o processo de observação nas pesquisas qualitativas. MINAYO (1994), oferece as seguintes considerações sobre as metodologias de pesquisa qualitativa, indicando que as mesmas devem ser entendidas:

"(...) como aquelas capazes de incorporar a questão do significado e da intencionalidade como inerentes aos atos, às relaçōes e às estruturas sociais, sendo essas últimas tomadas tanto no seu advento quanto na sua transformação, como construções humanas significativas." (MINAYO, 1994: 10)

O caráter de constituir-se enquanto procedimento científico não se perde por não estar operacionalizado em números, conforme as considerações da mesma autora apresentadas a seguir:

"A introdução dessa definição insere conseqüências teóricas e práticas na abordagem do social. A primeira delas é uma interrogação sobre a possibilidade de se considerar científico ou não um trabalho de investigação, que ao levar em conta os niveis mais profundos das relaçōes sociais, não pode operacionalizá-lo em números e variáveis, critérios usualmente aceitos para emitir juizo de verdade no campo intelectual. Ora, essa questão remete às próprias entranhas do positivismo sociológico que apenas reconhece como ciência a atividade 'objetiva', capaz de traçar leis que regem os fenômenos, menosprezando os aspectos chamados 'subjetivos', impossiveis de serem sintetizados em dados estatísticos." (MINAYO, 1994: 10)

Dentro desta perspectiva, a abordagem qualitativa não deixa de se ocupar das operações mentais que validam sua produção de

\footnotetext{
${ }^{8}$ A discussão sobre abordagens qualitativas foi realizada por Minayo \& Sanches (1993) tendo como foco central a comparação com as abordagens quantitativas, chegando à conclusão de que ambas podem ser complementares na compreensão da realidade social. Torna-se importante, portanto, o debate sobre a diversidade humana no que diz respeito à linguagem comunicativa.
} 
conhecimento. Pelo contrário, o rigor tanto na fase inicial de definições teórico-conceituais e práticas de pesquisa, como durante o desenvolvimento do campo de pesquisa, estão sempre presentes, e constituem os critérios que validam o processo de produção do conhecimento ao indicarem os parâmetros, limites, escolhas, etc., tomados no curso das pesquisas.

\section{Tipo de estudo}

Ao concentrar minha atenção na análise de um Centro de SaúdeEscola, preocupei-me, inicialmente, em definir quais os parâmetros que justificariam a escolha de um único Centro de Saúde-Escola a ser estudado como sendo suficiente à reflexão proposta.

Fundamentalmente, a noçāo de cultura organizacional supōe, como já discutido anteriormente, a existência de um conjunto próprio de significados e práticas criados dentro dos limites de uma unidade social. Neste caso, uma organização apensa à uma instituição maior: a Faculdade de Ciências Médicas da Santa Casa de São Paulo. É sob este enfoque teórico que a escolha do estudo de caso ocorreu, sendo necessárias, portanto, algumas considerações que o definam com maior precisão.

O estudo de caso supõe a escolha de uma unidade dentro de um conjunto de unidades. Pode haver similitude entre aquela escolhida e as outras, mas será ao mesmo tempo distinta já que as particularidades que a definem como tal a tornam singular. $O$ caso escolhido deve ser muito bem delimitado e a justificativa de sua escolha deve esclarecer os porquês, tanto sobre os aspectos teóricos, como dos práticos que viabilizam a investigação.

A escolna do caso vai estar justificada a medida que o pesquisador tiver claro o valor que o caso escolhido tiver em si mesmo. Então, temos que ao mesmo tempo que as semelhanças entre os casos exista, o caso escolhido manterá suas particularidades e a sua escolha ocorre justamente por estes elementos que o distinguem de outros. 
As caracteristicas do estudo de caso são as seguintes, segundo LÜDKE \& ANDRÉ (1986):

- visam à descoberta de novos elementos importantes para qualquer estudo, mesmo que este tenha partido, inicialmente, de pressupostos teóricos;

- devem levar em conta o contexto em que o objeto está situado, considerando as ações, percepções, comportamentos e interações produzidas no contexto;

- retratar a realidade de forma completa e profunda, revelando a multiplicidade de dimensões presentes numa situação ou problema; ênfase na complexidade natural das situações através da inter-relação entre as pessoas;

. devem utilizar várias fontes de informação, assim como várias técnicas de coleta de dados;

- produzir relatos completos das experiências, proporcionando ao leitor indagações que, por sua vez, produzam reflexões sobre a sua própria situação;

- realizar uma apreciação efetiva do conflito social através da apresentação dos diferentes pontos de vista presentes numa situação social;

- proporcionar ao leitor conclusōes próprias mas, também, suscitar as conclusões dos próprios leitores;

- por fim, os relatos devem ser acessiveis e conter desenhos, colagens, fotos, etc. que sejam consideradas importantes ao estudo; também devem ser ilustrados por figuras de linguagem, citações, etc. (LÜDKE \& ANDRÉ, 1986: 18$)^{9}$

\footnotetext{
${ }^{9}$ Cf. também sobre estudo de caso os seguintes autores: De Bruyne (1982) e Triviños (1995).
} 
Não há, portanto, uma exclusão do pensar os outros casos mas, sim, uma contribuição à reflexão dos outros casos, tomando-se aquele estudo por referência. Mergulhar no significado atribuído pelos agentes sociais envolvidos, descrever e discutir sobre as concepções de trabalho percebidas e compreendidas e saber compreender um caso na totalidade que se insere, são algumas das exigências postas pelos estudos de caso. 0 aprofundamento nestes aspectos contribui não para um conhecimento exclusivo da unidade estudada, mas em sua capacidade de generalizar para as outras unidades, podendo contribuir para a reflexão deste tipo de organização.

\section{O processo de observação}

À complexidade dos estudos de caso, como indicado anteriormente, somam-se o rigor nos procedimentos e a permanência ampliada no campo de pesquisa, fase na qual se procura cercar as pessoas que foram escolhidas pelo pesquisador como informantes. São necessárias algumas considerações, portanto, de como foi a aproximação, os primeiros contatos, a autorização para a realização da pesquisa, enfim, todo o esforço no sentido de tornar bem definidas para os agentes sociais as intenções enquanto investigador, fundamentalmente, as que dizem respeito aos objetivos e finalidades da pesquisa. Enfim, tornar o trabalho de investigaçăo legítimo dentro da organização, procurando cercar os agentes sociais não só de questionamentos cuja finalidade seriam aquelas exigidas pela pesquisa, mas ampliando os contatos com estes agentes no sentido de poder refletir e possibilitar a reflexão dentro do espaço social constituído pela organização.

Os primeiros contatos foram realizados no ano de 1995 quando participava, juntamente com o atual diretor do Centro de Saúde-Escola, de um projeto de pesquisa intitulado: Caracterização do Modelo Técnico- 
Assistencial de Centros de Saúde-Escola da Cidade de São Paulo ${ }^{10}$. Nossos interesses eram compativeis principalmente no que diz respeito às metodologias das pesquisas qualitativas, além da temática abordada que tangenciava a área de estudos em administração, sub-área de recursos humanos em saúde.

As justificativas colocadas pelo diretor do Centro de SaúdeEscola eram as de que naquele momento tanto os serviços, como o ensino e a pesquisa, passavam por transformaçōes significativas. Havia interesse, portanto, em repensar juntamente com os profissionais envolvidos no Centro de Saúde-Escola os rumos que a organização tomaria frente às mudanças sociais refletidas no cotidiano do serviço e, também, pelos interesses em modificar as estruturas internas da organização do trabalho e, conseqüentemente, do ensino e da pesquisa.

Iniciei o trabalho de pesquisa entrevistando o diretor do Centro de Saúde-Escola, objetivando abrir as possibilidades de pensar aquele caso segundo a perspectiva teórica que cultivava naquele momento. Ou seja, a apreensão daquela realidade, via conceito de cultura organizacional, necessitava de elementos que evidenciassem as suas particularidades iniciando-se, assim, a constituicão de um rol de evidências que contribuíram para a formulação do projeto de pesquisa.

Em seguida, mantive contatos com uma das assistentes sociais que expós, com clareza e precisão algumas considerações sobre a história e a organização do serviço, e, também, com um dos médicos - também professor do departamento de Medicina Social da Faculdade de Medicina da Santa Casa de São Paulo - que contribuiu em muito com informações precisas sobre as concepções que nortearam a organização na sua fundação.

\footnotetext{
${ }^{10}$ Projeto desenvolvido no Instituto de Saúde (Secretaria Estacual de Saúde - SP), sob a coordenação geral da professora Elza Lobo, participação dos diretores do CS-Escola Barra Funda, do CS-Escola da Faculdade de Medicina da USP e do CS-Escola da Faculdade de Saúde Pública da USP, da professora Mara Helena de Andréa Gomes do departamento de Medicina Preventiva da Universidade Federal de São Paulo-E.P.M., do professor Cláudio Gastão da Faculdade de Saúde Pública da USP, além dos alunos do curso de aprimoramento em Saúde Coletiva desenvolvido naquela instituição.
} 
Estas entrevistas foram registradas utilizando-se a técnica de gravador. Além dos procedimentos básicos exigidos pela ética na pesquisa, tais como apresentação formal do pesquisador e do objeto de investigação, procurei manter nas transcrições a exatidão da expressão oral dos entrevistados.

Posteriormente, mantive contato com o diretor, sempre procurando discutir os rumos da pesquisa, ora questionando sobre a história do Centro de Saúde-Escola, ora ouvindo suas consideraçōes sobre as finalidades fundamentais da organização: a assistência, o ensino e a pesquisa. Foram informações relevantes à elaboração do projeto de pesquisa e, também, marcaram minha presença naquele espaço o que possibilitou a apresentação formal a alguns dos profissionais envolvidos no Centro de Saúde-Escola, abrindo, assim, os caminhos a serem percorridos para a realização do projeto de pesquisa e, posteriormente, para o processo de coleta de dados.

\section{As técnicas de pesquisa}

A técnica de entrevista semi-estruturada foi escolhida como aquela fundamental à coleta de dados. Um dos motivos básicos da escolha estaria nas exigências do próprio objeto de investigaçāo, que é de natureza qualitativa. Este instrumento de coleta de dados viabiliza uma interação mais aprofundada com aqueles que participam como informantes já que não exclui a possibilidade de flexibilizar o roteiro que foi estabelecido previamente (Anexo I), seja alternando as perguntas, seja respeitando a ordem que o próprio entrevistado vai estabelecendo no desenvolvimento do diálogo entre as partes. Ou seja, foram respeitadas as seqüèncias por vezes impostas pelos entrevistados ao relembrarem fatos, personagens, etc., dando-Ihes a liberdade de seguir com suas falas caminhos que muitas vezes trilharam em suas vidas.

Segundo TRIVIÑOS (1995), "a entrevista semi-estruturada é um 
dos principais meios que tem o investigador para realizar a coleta de dados", e dá seqüência ao seu raciocínio da seguinte forma:

"(..) no enfoque qualitativo podemos usar a entrevista
estruturada, ou fechada, a semi-estruturada e a entrevista
livre ou aberta. Estas duas últimas são mais importantes
para esta classe de enfoque. Não obstante isso, apesar
de reconhecer o valor da entrevista aberta ou livre, que
não deve ser confundida com entrevista não-diretiva,
queremos privilegiar a entrevista semi-estruturada porque
esta, ao mesmo tempo que valoriza a presença do
investigador, oferece todas as perspectivas possiveis
para que o informante alcance a liberdade e a
espontaneidade necessárias, enriquecendo a
investigação." (TRIVIÑOS,1995: 145)

Colocada desta forma, a entrevista semi-estruturada é composta de um foco principal, e este, por sua vez, é orientado pelo objeto de investigação ou pelos pressupostos de pesquisa. $O$ desenrolar da entrevista não obedece a parâmetros rígidos, mas procura encaminhar o desenvolvimento do diálogo de acordo com os interesses em questão. Também podem surgir colocaçōes que despertem no pesquisador outros questionamentos até então não presentes em seu trabalho de investigação. ${ }^{11}$

Um outro aspecto importante de ser comentado é a utilização do recurso da técnica de gravador. O que se tem em mente, via de regra, é a facilidade com que se pode captar e manter os registros em sua totalidade, podendo inclusive recolocar algumas questões ou mesmo pedir ao informante que repita ou esclareça algo dito anteriormente, o que não se pode alcançar com os registros manuscritos. O que se depreende desta técnica é a abertura permitida para se alcançar uma quantidade maior de informaçōes ao mesmo tempo que estas vão sendo questionadas, revistas ou simplesmente comentadas, tanto pelo informante como pelo entrevistador.

\footnotetext{
${ }^{11}$ Cf, também sobre a técnica de entrevistas De Bruyne et al. (1982) e Quivy \& Campenhoudt (1992).
} 
Os registros gravados criam, também, maiores oportunidades para o informante se confrontar com as questōes postas pelo pesquisador, ao mesmo tempo que podem criar bloqueios no informante na exposição de suas considerações, seja por suas próprias caracteristicas pessoais, seja pelo comportamento do pesquisador. A gravação, portanto, não resolve todos os problemas na coleta de dados, nem tampouco pode suplantar a outra forma de registro de informação que é a manuscrita. A sua definiçāo e desenvolvimento diz respeito às formas de coleta de dados de história de vida e de depoimentos pessoais ${ }^{12}$, o que não a exclui de problemas tanto em sua aplicação, como na fase posterior de leitura do material coletado e a respectiva formulação das categorias elaboradas a partir do pensamento dos informantes. Sobre isso, QUEIROZ (1983) tece os seguintes comentários:

"(...) Suas maiores qualidades (da técnica de gravação), quando empregadas dentro das limitaçōes de tempo e da não-intervenção do pesquisador, são: a descoberta de novas facetas do real; a critica aos dados já colhidos por outras técnicas; a auto-crítica do pesquisador, diante das revelaçōes do discurso do informante. Seja como for, para qualquer trabalho que ultrapasse o levantamento de problemas e apresentação de dados, sua associação com outras formas de coleta se torna imprescindivel." (QUEIROZ, 1983: 72)

Uma outra forma de coleta de dados utilizada nesta pesquisa foi através da participação nas reuniōes gerais promovidas no Centro de Saúde-Escola. Esta participação possibilitou uma observação de um ponto de vista diferenciado pelos seguintes aspectos: as discussōes sobre os problemas ocorridos ou previstos de ocorrer são postos pelos setores da organização ou individualmente possibilitando a coleta de uma série de informaçōes novas ou a confirmação de outras já obtidas; as reuniōes contam com a participação de todos os funcionários, o que amplia as

\footnotetext{
${ }^{12}$ Importante contribuição sobre a técnica de gravação pode ser encontrada na obra de M. I. P. de Queiroz Variações sobre a Técnica de Gravador no Registro de Informação Viva, 1983.
} 
possibilidades de exposição dos diferentes posicionamentos; os pontos de vista sobre os vários aspectos do trabalho (de problemas localizados, até divergências na concepção e encaminhamento dos problemas) são colocados coletivamente; a produção do trabalho é apresentada de forma crítica e não exclusivamente sob a forma de estatísticas de produção, gerando debates e promovendo novas discussões.

As reuniōes propiciaram, também, registros importantes durante 0 trabalho de campo, muitas vezes gerando oportunidades de verificação de considerações coletadas nas entrevistas individuais sendo postas perante a totalidade dos funcionários presentes às reuniōes. Estas reuniōes configuram-se como um momento de exposição do que foi realizado e, também, das críticas e contribuições que surgem como conseqüência desse processo. São espaços de participação que geram um movimento importante de ser captado. Um movimento que quebra a rotina do trabalho impondo uma outra forma de participação.

Compor o registro destas informaçōes consistiu numa tarefa dificil pela própria dinâmica de como apresentavam as reuniões. Os registros foram todos manuscritos, procurando abarcar o maior número possível de informações colocadas pelos participantes. Também foi considerada a ordem estabelecida às reuniōes, tanto na sua seqüência, quanto das intervençōes que irrompiam a ordenação de apresentação.

Quando da ocorrência de discussões que indicavam conflitos de interesses entre setores ou pessoas, fosse de ordem prática ou conceitual, as informações registradas na íntegra sofriam uma redução pela impossibilidade de acompanhar os diálogos que se desenvolviam. Passavam, então, de registros literais a registros em forma de código, procurando indicar campos de conflito segundo a ordem e $o$ dimensionamento que os mesmos poderiam assumir dentro da organização.

A coleta de dados, neste caso, ocorreu sem que houvesse participação do pesquisador. Ao iniciar as reuniōes, o diretor do Centro de Saúde-Escola indicava minha participação na reunião apresentando minhas 
intenções de pesquisa, assim como salientava a importância do trabalho para os presentes. Durante o desenvolvimento das atividades, o registro das informações eram intercalados com o esclarecimento de dúvidas que surgiam no desenrolar das reuniōes. Para isso, procurei estar próximo de informantes, durante as reuniões, com os quais já mantinha algum contato e sabia poder contar com suas consideraçōes e esclarecimentos. Quando não, procurava durante os intervalos, ou mesmo ao final, esclarecimentos que elucidassem algumas passagens que não tivessem ficado claras.

Um importante fato ocorrido durante do campo de pesquisa, foi o convite para participar da elaboração das categorias de análise dos trabalhos de avaliação do serviço ao final do ano de 1997, desenvolvidos pela direção da unidade.

Esse trabalho de avaliação tinha por objetivo promover uma participação diferenciada dos funcionários durante a apresentação da produção anual de serviços e do desenvolvimento do ensino, na reunião de dezembro daquele ano. A estratégia adotada foi a de que as equipes de trabalho (saúde do adulto, da criança, mental, etc.) respondessem algumas questões apresentadas, cujo conteúdo versava, basicamente, sobre relações de trabalho entre os funcionários, relações entre as equipes e a viabilização da prestação de serviços, e, por fim, relações entre equipes de trabalho, direção e administração do Centro de Saúde-Escola.

As consideraçōes sobre esta atividade e suas conseqüências estão expostas no Capitulo 4, inserindo-as, portanto, na reflexão sobre as formas escolhidas internamente para o estabelecimento da comunicação $e$ para a realização do trabalho.

Outra forma de coleta de dados consistiu no levantamento e leitura de documentos produzidos dentro do próprio Centro de SaúdeEscola. São documentos contendo dados sobre as atividades de assistência - relativos aos anos de 1996/97, documentos anuais para manutenção dos vínculos administrativos entre o Centro de Saúde-Escola, a Irmandade da Santa Casa de Misericórdia de São Paulo, a Secretaria de Estado da Saúde 
e a Fundação Arnaldo Vieira de Carvalho, além de alguns trabalhos acadêmicos produzidos quando da formação do Centro de Saúde-Escola, no final dos anos 60 , que refletem e justificam a sua formação. Foram contribuições importantes que serviram à reflexão.

As três formas de coleta de dados - levantamento direto de informação junto aos funcionários, participação em reuniōes e análise de documentos e textos - encerraram uma série de informações, as quais apresento nos capítulos subseqüentes, procurando, primeiramente, organizá-las em sua forma histórica, isto é, surgimento, primeiros passos, transformações e momento atual, para em seguida refletir através das informações coletadas junto aos agentes sociais envolvidos com o trabalho naquela unidade básica de saúde.

\section{Desenvolvimento e organização do campo de pesquisa}

A aproximação com os funcionários ocorreu lentamente e deveuse, principalmente, às conexões que foram sendo estabelecidas desde as primeiras idas ao Centro de Saúde-Escola. Foi uma aproximação construída passo-a-passo, obedecendo uma distribuição que contemplasse representantes das várias áreas de atuação no Centro de Saúde-Escola subdivididos entre as respectivas categorias profissionais. Estas, por sua vez, subdivididas nos niveis médio e superior de formação. Não foi constatada nenhuma dificuldade em agendar as entrevistas, com apenas uma exceção que alegou, por duas vezes, não ter tempo disponivel para ser entrevistado. O restante das entrevistas ocorreu sem nenhuma recusa e com o cumprimento dos horários agendados.

As escolhas daqueles que seriam entrevistados ocorreu conforme os próprios funcionários iam indicando outros colegas em suas entrevistas. Às vezes a indicação era dada pelo valor que o tempo de serviço de alguns funcionários representava, ou pelo posto de destaque que ocupavam naquele momento, ou até mesmo por algum trabalho de pesquisa, 
assistência ou ensino desenvolvido ou pelo qual havia interesse. Nestes casos procurei verificar o grau de proximidade entre os funcionários, caracterizando-os pelas relações que os mesmos pudessem ter através da amizade, interesse exclusivo por um colega de trabalho, ou até mesmo admiração pelo tempo e atividades de trabalho desenvolvidas na história do Centro de Saúde-Escola.

Foram realizadas 21 entrevistas divididas da seguinte forma: 3 funcionários do setor administrativo, 4 auxiliares de enfermagem, 4 médicos, 3 enfermeiras, 1 psicólogo, a médica assistente de direção, as 2 assistentes sociais, o médico diretor técnico e 2 professores do departamento de Medicina Social. Foram incluidos nestes números as entrevistas realizadas na fase inicial do projeto de pesquisa.

Os entrevistados demonstraram, durante toda a execução do campo de pesquisa, interesse pelo trabalho de investigação, colocando-se disponiveis não só pelo tempo dispendido junto ao pesquisador, como também pelo interesse cultivado durante o momento das entrevistas. $O$ que se pode depreender da situação de entrevista, no geral, é que existe uma disposição interna em participar deste tipo de atividade, fato constatado pela facilidade com que as entrevistas evoluiam. Por exemplo, nos primeiros momentos das entrevistas onde geralmente o entrevistado ainda tem alguns bloqueios para expressar suas idéias, seja por desconhecer as reais intenções do pesquisador, seja por não confiar ainda o suficiente no pesquisador para poder expor suas considerações pessoais, foram facilmente superados em todas entrevistas.

Esta disponibilidade tem por suposto a proximidade destes funcionários, tanto os de nivel médio como os de nivel superior, com as atividades de pesquisa e ensino desenvolvidas na organização. São funcionários preparados, de certa forma, pois vivenciam estas atividades diariamente; uns mais diretamente, outros menos. É, como se percebe, um ambiente favorável às atividades de pesquisa, o que era de se esperar pois, dentro de seus propósitos iniciais, o Centro de Saúde-Escola foi concebido 
justamente para que as atividades de ensino e pesquisa fluissem juntamente com as novas experiências desenvolvidas na assistência.

As entrevistas iniciavam-se com perguntas diretas sobre o nivel de formação, formação em saúde, ano de inserção no Centro de SaúdeEscola. Além de serem informações importantes à investigação, serviram ao aquecimento inicial do diálogo. Logo, as perguntas inseridas no roteiro de entrevista passavam a ser apresentadas, mas sempre permitindo que o entrevistado ficasse à vontade para dar seqüência às suas idéias conforme Ihe conviesse. Por exemplo, se ao responder sobre sua formação em saúde passasse a tecer considerações sobre suas passagens pelo Centro de Saúde-Escola, a entrevista seguia conforme este direcionamento. Não houve, portanto, rigidez na apresentação da seqüência do roteiro.

A situação de entrevista foi direcionada, a medida do possivel, para que um clima favorável e de confiança ficasse estabelecido entre as partes. Foi considerado o fato de que os entrevistados falariam de seu trabalho, situação que, por um lado, poderia causar constrangimentos e, por outro, poderia bloquear informaçōes importantes. Uma das garantias para a superação desse problema foram as colocações inciais sobre o obejto de investigação, minhas intenções pessoais com relação à pesquisa e, fundamentalmente, a garantia de que as gravaçōes e subseqüentes transcrições e análise não conteriam elementos que pudessem identificar os entrevistados que contribuíram com os depoimentos. Esta foi a rotina estabelecida, primeiro, porque é aquela que deve ser entendida, neste e em outros trabalhos de investigação, como procedimento básico no campo de pesquisa; segundo, pelas garantias de que as informaçōes seriam pensadas e transmitidas com tranqüilidade e confiança, já que a relação entrevistadoentrevistador estaria mediada por garantias alicerçadas na ética de pesquisa exigida nestas situações.

O tempo médio das entrevistas foi de uma hora e meia, tempo que demonstrou ser suficiente para que os entrevistados pudessem relembrar fatos, narrar histórias, refletir sobre sua prática profissional e 
sobre a população a qual são oferecidos os serviços.

\begin{tabular}{ll}
\hline \multicolumn{2}{c}{$\begin{array}{c}\text { Distribuição dos funcionários do Centro de Saúde-Escola Barra } \\
\text { Funda por categorias profissionais, 1997. }\end{array}$} \\
\hline Auxiliar administrativo & 09 \\
Auxiliar de enfermagem & 18 \\
Auxiliar cons. dentário & 02 \\
Auxiliar de Saúde & 01 \\
Auxiliar de serviços & 04 \\
Enfermagem técnica de saúde & 02 \\
Enfermeira chefe administrativa & 01 \\
Dentista & 02 \\
Médico & 12 \\
Médico diretor técnico & 01 \\
Médico suplente & 01 \\
Assistentes sociais & 02 \\
Psicólogo & 01 \\
TOTAL & 61 \\
\hline
\end{tabular}

As transcrições das fitas gravadas foram realizadas integralmente. Não necessariamente foram incluídos os comportamentos observados durante os encontros, mas foram registradas durante as entrevistas algumas ênfases dadas em determinados assuntos ou determinados fatos narrados durante a situação de entrevista, os quais tornaram possível a análise dos dados. 


\section{CAPÍTULO 3 - HISTÓRICO DA ORGANIZAÇÃO}

Ao situar historicamente o surgimento do Centro de Saúde-Escola Barra Funda e do Bom Retiro', considerando, principalmente, algumas passagens marcantes, personagens de sua história, assim como a indicação de algumas referências importantes em seu momento atual, faz-se mister, primeiramente, expô-lo em suas relações com o contexto maior em que foi pensado, planejado e executado. Ao mesmo tempo, deve ser construido um diálogo desse contexto maior com os elementos próprios de sua história, isto é, a expressão de suas particularidades nesse contexto, evidenciando as conexöes entre concepçōes, marcos históricos, personagens e mudanças ocorridas na cidade que marcaram a sua trajetória.

Fruto de um convênio estabelecido entre três entidades: Fundação Arnaldo Vieira de Carvalho (F.A.V.C.), Irmandade da Santa Casa de Misericórdia de São Paulo (I.S.C.M.-SP) e Secretaria de Estado da Saúde de São Paulo (SES-SP), no ano de $1967^{2}$, no princípio foi denominado de Centro de Saúde Experimental da Barra Funda e Bom Retiro. Sua formação tem uma intima ligação entre novas concepções sobre - processo saúde-doença e, consequentemente, novas práticas de organização dos serviços de saúde, assim com também a inserção de novos modelos de ensino, associados às práticas anteriores, que vieram inovar o campo do ensino e da prática em saúde pública.

No final da década de 60 , ocorreu uma profunda transformação no plano administrativo, a qual alterou significativamente os rumos da

\footnotetext{
1 Foram utilizadas na construção deste capítulo informações coletadas através de entrevistas semi-estruturadas, análise de documentos intemos, textos produzidos em sua história e, também, os registros coletados durante as participações na reuniões gerais promovidas semestralmente.

${ }^{2}$ A assinatura do convênio data de janeiro de 1967. Em junho do ano seguinte, 1968, foi iniciado o censo demográfico da região, além de um levantamento cadastral da área. Dia 16 de abril de 1969 é a data exata de sua inauguração. (Entrevistado $n^{\circ} 1$ )
} 
administração pública na Secretaria de Estado da Saúde. Foi a chamada reforma Leser, que elevou o nome do professor Walter Leser. Através de decreto de $1967^{3}$, ficou estabelecido o seguinte plano de implantação da reforma (Sá, 1978):

1) objetivos: eficiência operacional, eficiência administrativa e valorização do servidor público;

2) diretrizes: vinculação à realidade existente e prioridade para o nível periférico;

3) programas: eficiência operacional, regionalização governamental, eficiência administrativa, valorização do servidor público. ${ }^{4}$

Neste mesmo ano a proposta apresentada ao governador Abreu Sodré ${ }^{5}$ indicava alguns conceitos de extrema importância no entendimento de sua formação. Por exemplo, a integração dos serviços de saúde em nível local; a descentralização executiva, a qual previa a autonomia para as unidades de prestação direta de serviços; a centralização normativa, trazendo a noção de uniformidade na execução dos serviços e uma supervisão especializada; por fim, os sistemas permanentes de planejamento, envolvendo a produção de conhecimentos em epidemiologia, estatísticas de saúde e treinamento de pessoal, além da manutenção de um vínculo comunicativo entre órgãos centrais e unidades periféricas e treinamento contínuo de pessoal. ${ }^{6}$

A reforma veio reforçar o papel dos estados, unidades administrativas da federação, enquanto produtores de bens e serviços e, também, do papel de liderança que catalizasse os recursos administrativos e viabilizasse a reforma. O momento, no estado de São Paulo, era de intenso desenvolvimento urbano $e$ industrial, consequentemente, apresentando uma mudança qualitativa da demanda social que justificasse

\footnotetext{
${ }^{3}$ Decreto $\mathrm{n}^{\circ} 48.040$ de $1^{\circ}$ de junho de 1967

${ }^{4}$ Cf. Sá, E.N. de C., Uma Experiencia de Reforma Administrativa da Secretaria de Estado da Saúde, 1978.

${ }^{5}$ Assumiu o govemo estadual em 1967 permanecendo no cargo até 1970.

${ }^{6}$ Ibidem. p. 40.
} 
os novos rumos da administração em saúde. Mudanças que implicavam, inclusive, em novas reivindicações de movimentos com maior participação social. $^{7}$

O centro de saúde experimental da Barra Funda e Bom Retiro, criado naquele momento, esteve sob a influência dessas novas idéias e determinaçōes oficiais que passaram a orientar a organização dos serviços de saúde.

Segundo um dos professores entrevistados, participante da formação do centro de saúde-escola, o primeiro convênio entre as entidades foi assinado em 1965, durante a primeira gestão do professor Leser na Secretaria de Estado da Saúde. Depois, já na segunda gestão, de 1967 a 1970, foi assinado o convênio, e em 1968 o centro de saúde passa a funcionar de fato. Quanto à atuação do professor Leser e sua importância para a concepção e execução das novas atividades de assistència, ensino e pesquisa propostas naquele momento, o entrevistado tece as seguintes consideraçōes:

"O professor Leser participou ativamente porque foi ele, como secretário, quem desenhou a forma do convênio, que é uma coisa interessante: é o primeiro convênio em parceria em que uma determinada área da cidade era atribuida a responsabilidade da saúde pública à uma Faculdade de Medicina. Foram dois centros de saúde criados ao mesmo tempo: o da Escola Paulista de Medicina, que ficava lá na Vila Mariana, e o centro de saúde da Barra Funda. (...) Os dois surgiram simultaneamente, com o mesmo modelo de convênio e no modelo de convênio ficava bem claro o seguinte: uma determinada área da cidade, no caso do centro da Barra Funda, seria delegada à Faculdade de Ciências Médicas da Santa Casa e é interessante, também, que o convênio veio vincular a idéia de saúde pública, a obrigatoridade do diretor desse centro de saúde ser um médico sanitarista. Já estava imbricada na idéia de centro de saúde experimental. $O \mathrm{dr}$. Leser era uma pessoa que fazia tudo com uma visão estratégica, assim muito clara. Acho que já era o embrião da idéia do Leser, nesses

\footnotetext{
${ }^{7}$ Ibidem. p. 17.
} 
momentos, a de ter um centro de saúde-escola experimental, onde vocé seria ao mesmo tempo centro de saúde integrante da rede. Teria como objetivo formar alunos de graduaçăo médica, incentivar, estimular $e$ servir de demonstração para esse profissional. Ele estava pessoalmente empenhado em achar uma estratégia na secretaria de saúde que era a do médico sanitarista. Pensando bem ele começou em 1965 e muito mais tarde, quase dez anos depois, é que foram sendo formados os médicos sanitaristas em quantidade suficiente para atender a toda a rede. Então há uma nítida vinculação entre centro de saúde, carreira de médico sanitarista e a formaçāo de um quadro de profissionais estratégicos que seriam os médicos sanitaristas, mas também de outros profissionais, como as enfermeiras de saúde pública, que era uma coisa incipiente ainda na época.

(...) O centro de saúde, é interessante recuperar isso, era um movimento muito forte. Ideológico mesmo. Concepção, movimento em andamento. Não era só médico sanitarista. Eram também essas outras categorias profissionais envolvidas. Mas é que o médico sanitarista foi o recurso estratégico e no nosso centro de saúde, a gente definia este papel da seguinte forma: o estudante de medicina passava lá para aprender como trabalhar com a comunidade." (Entrevistado $n^{\circ} 1$ )

A formação de médicos qualificados ao trabalho nessas unidades de serviço de saúde era elemento fundamental naquele momento. Os vínculos da reforma com esses novos ideais que se apresentavam na formação e prática dos médicos teve sua expressão, portanto, através de personagens como o doutor Walter Leser.

\section{A formaçāo do Centro de Saúde Experimental da Barra Funda}

A formação do centro de saúde experimental da Barra Funda ocorre num momento de grandes mudanças, tanto no plano administrativo, como no das concepções que norteiam as práticas de saúde, como já afirmado anteriormente.

Uma abordagem histórica da organização dos serviços de saúde, no final dos anos 60 , voltada à análise do modelo tecnológico, é 
caracterizada por MENDES-GONÇALVES (1994) da seguinte forma: o objeto de trabalho privilegiava a assistência médica individual na rede de centros de saúde, através de ações programáticas planejadas e embasadas em conhecimentos epidemiológicos, assistência extensiva a grupos populacionais e não mais definidos por moléstias específicas, um alvo populacional definido (marginalizados da sociedade) e, a generalização das ações a todos os niveis de atenção à saúde; quanto aos instrumentos de trabalho, houve a adoção dos centros de saúde como unidades sanitárias polivalentes, com responsabilidade local (populacional e espacial), as quais passaram a ser executoras das ações em saúde, criação de um sistema de informaçōes (criando-se a base para o planejamento) e programas de assistência (crianças e mulheres, por exemplo); o aparato institucional teve na disseminação dos centros de saúde sua principal característica. ${ }^{8}$

A análise de MENDES-GONÇALVES (1994) contribui para o entendimento das idéias contidas no projeto de formação da unidade investigada no tocante ao objeto de trabalho definido em seus pressupostos e finalidades: o trabalho deveria voltado à comunidade. São os seguintes os objetivos gerais do centro de saúde experimental propostos em seus primórdios:

"1 - Promoção, proteção e recuperação da saúde da
população residente na área do sub-distrito da Barra
Funda, através da assistência médico-sanitária e dos
métodos educativos disponíveis, visando a redução da
morbidade e da mortalidade, e a aquisição de
conhecimentos pelos indivíduos, pelas famílias e pela
comunidade da sua responsabilidade na problemática de
saúde;
2 - Ensino de saúde pública e das demais disiciplinas do
departamento de Medicina Social através de estágios

\footnotetext{
${ }^{8}$ Mendes-Gonçalves (1994) reconstrói em seu trabalho a história dos modelos tecnológicos no Brasil, dividindo-os em três momentos: $01^{\circ}$ modelo, do século XIX ao início do século $X X$, com as seguintes características: a doença como centro do modelo e desvinculada das questões sociais, com campanhas sanitárias e baseado num modelo polítco autoritário de intervenção social; o $2^{\circ}$ modelo, do início do anos 20 até 1966, acresce aos elementos anteriores a questão educacional - prevenção e promoção à saúde, simultaneamente, com o surgimento dos centros de saúde e a ênfase nas questões sociais.

Cf. também Merhy, E., O Capitalismo e a Saúde Pública, 1987.
} 
para alunos de medicina, enfermagem e outros profissionais de saúde;

3 - Treinamento de pessoal em saúde pública, tanto para atividades na unidade como para a secretaria de saúde;

4 - Realização de pesquisas operacionais aplicadas à saúde pública, desenvolvendo métodos e técnicas que possam ser estendidos à rede de unidades sanitárias do estado de São Paulo." (MERCADANTE, 1970: 10; SIMON, 1970: 13)

São objetivos genéricos mas que contêm a essência do que se imaginava em termos de uma atuação voltada para a denominada "comunidade" (SIMON, 1970: 2). Estava em debate, naquele momento, a polarização de duas idéias: por um lado, um enfoque mais antigo voltado à assistência individual; por outro lado, um enfoque voltado para a realidade social, podendo não só observar como intervir nas ocorrências patológicas como, também, nas condições de vida da população. (Entrevistado $n^{\circ} 1$ )

$\mathrm{Na}$ análise sobre o contexto de formação do centro de saúde experimental da Barra Funda, podem ser recuperadas as reflexões de DONNANGELO (1976) através da análise histórica da organização dos serviços de saúde no Brasil analisando, por um lado, a medicina como prática social e, por outro, contemplando a estrutura das sociedades concretas, identificando a medicina comunitária com a dimensão dos serviços. Ou seja, a configuração que os serviços de saúde assumiram tendo por objetivo maior as categorias sociais até então excluídas do processo de medicalização.

Tendo por objeto, portanto, atingir as camadas mais pobres da população, segmentos sociais muitas vezes conceitualmente diluídos na noção de comunidade, instaura-se uma nova prática de saúde cujas bases concretas de sua organização estavam centradas no trabalho conjunto de vários profissionais. As práticas profissionais tornaram-se complementares e extensivas às camadas até então não assistidas pelo sistema de saúde em vigor. A medicina comunitária, denominação dada a esse movimento, foi um fenômeno que se desenvolveu nos anos 60 cujo postulado era a 
subordinação da prática médica à dimensão social do processo saúdedoença, superando o corte entre aspectos orgânicos e psico-sociais.

Estes elementos de referência histórica e teórica da organização dos serviços de saúde colocam o contexto brasileiro dos anos 60 dentro de um movimento maior que ocorria em países desenvolvidos industrialmente, como os Estados Unidos, por exemplo, e se expandiam para outros paises. Dentro desta perspectiva pode ser entendido o movimento de transformação operado a partir da reforma administrativa na secretaria de estado da saúde em São Paulo, nos anos 60, e seus desdobramentos tanto na organização geral dos serviços, quanto na participação de escolas médicas que deveriam necessariamente reordenar o ensino médico e a formação de outros profissionais.

\section{A organizaçăo}

A criação da unidade sanitária na Barra Funda teve por base um planejamento que previa, primeiramente, o estabelecimento de atividades programadas, as quais estariam sustentadas em dados sobre os niveis de saúde da população da região de abrangência, além de partilhar de uma concepção sobre o processo saúde-doença que incluísse o conhecimento sobre a doença $e$, também, os fatores psico-sociais que pudessem influenciar nos agravos à saúde ${ }^{9}$. Foi considerada, também, a formação de uma equipe multiprofissional que conduziria os trabalhos, primeiro, de identificação da realidade local, segundo, da organização interna tendo por referência a anterior. Por fim, a participação da população também foi considerada importante na sua formação.

A justificativa de sua formação levou em consideração a definição de uma unidade sanitária como ponto de referência a uma determinada população, tendo em sua composição interna as qualidades de ser polivalente e dinâmica. Fator relevante em sua composição, era a 
responsabilidade pela execução de todas as atividades de saúde necessárias à população local, devendo estar sempre adaptada à dinâmica da realidade, cumprindo sua funcionalidade a medida que respondesse pelos problemas locais. (SIMON, 1970: 2)

A referência, portanto, para o ensino e a pesquisa, seriam os aspectos situacionais encontrados na região de abrangência da unidade sanitária. A estratégia desenvolvida, a partir de então, seria a de iniciar os trabalhos com um reconhecimento físico e demográfico da área. A partir destas definições, iniciou-se um censo, conforme a descrição apresentada a seguir:

"Este censo objetivava perspectivas de trabalho bastante novas, pois permitiria um levantamento de informações de todos os habitantes da área, que seria o próprio universo das pesquisas dos problemas de saúde da comunidade.

Antes de aplicar a pesquisa, o bairro, de uma área de $2,53 \mathrm{Km}^{2}$, foi percorrido para um reconhecimento precário de suas caracteristicas gerais.

(...) Como a necessidade de se efetuar este censo fosse urgente e a estimativa que pudesse ser feita basear-se-ia nos recenseamentos de 1940 e 1950, provavelmente distorcida pelo ritmo de crescimento desigual da cidade, foi programado o reconhecimento demográfico da área com a colaboração de líderes da comunidade, através do preparo que fizessem junto à população para aceitação e contribuição aos recenseadores." (SIMON, 1970: 4)

Numa perspectiva analítica, um dos entrevistados coloca a formação da unidade sanitária sob o enfoque educacional, num amplo sentido. Vejamos seu depoimento:

"Quando eu cheguei no centro de saúde experimental da Barra Funda, estavam preparando a instalação. (...) Foi a primeira atividade da qual participei, em agosto de 1968. Eu cheguei trabalhando numa pesquisa de campo. Já havia um projeto em andamento.

\footnotetext{
${ }^{9}$ Estas noções fazem parte do movimento desenvolvido na medicina denominado medicina integral. Cf. Donnangelo, 1976.
} 
O centro de saúde foi importante, primeiro, para se conhecer a realidade; segundo, para mostrar que deveria haver um instrumento e um conhecimento prévio da realidade para você fazer a implantação da unidade sanitária, dos programas e das atividades.

Acho que o próprio centro de saúde tinha essa dupla função: conhecer e demonstrar pedagogicamente, ou demonstrativamente, como deveria ser o tipo de atuação, de ação na saúde pública. Isso, desde o começo, era uma ação baseada neste conhecimento da realidade, uma idéia de responsabilização por uma determinada área.

(...) Ele tinha esse valor instrumental, também. Não era só um valor final. A partir dai se pensava quais eram os programas. A idéia do programa também já existia. A gente tinha que ter um programa de acordo com aquelas necessidades maiores da população: características demográficas, necessidades de saúde, características sociais. Montar os programas. Mas os programas já eram definidos: da mulher, da criança, do adulto e programas mental e bucal." (Entrevistado $n^{\circ} 18$ )

A formação do centro de saúde experimental da Barra Funda apoiou-se na idéia de que novas açōes em saúde fossem experimentadas, ou seja, colocadas em prática e que essas experiências fossem transmitidas à rede de serviços públicos. Era um local de experimentos. Pensado e preparado para experimentar novas práticas de ação em saúde, o que possibilitou viabilizar, ao mesmo tempo, novas formas de preparar profissionais para o trabalho em saúde, além de cumprir a sua finalidade com relação ao ensino. SIMON (1970) relata este aspecto:

"O planejamento do centro de saúde experimental da Barra Funda foi dificultado por absoluta falta de modelo de experiência semelhante no Brasil. Exigiu, portanto, em todas a suas etapas, estudos de adaptação de exemplos de outros países que mais se assemelhassem à realidade local. O levantamento cadastral e o censo demográfico da área, idealizado e levado a efeito pelo departamento de Medicina Social da Faculdade de Ciências Médicas da Santa Casa pretendeu não só o reconhecimento da realidade econômica, social e cultural da população, como também que alunos do curso médico tivessem uma 
experiência de trabalho social num ambiente extrahospitalar.

(...) A organização do C.S.E.B.F. foi, também, adaptada. Modelos de unidades sanitárias integradas serviram para fundamentar a estrutura organizacional e funcional. 0 regimento interno nāo póde ser concluído ainda, por serem freqüentes reformulações de funçōes $e$ competências e alguns serviços estarem ainda em fase inicial, como o laboratório.

As normas técnicas foram elaboradas com as mesmas dificuldades. A adequação de um modelo de Lima, Peru, foi utilizado, mas com restriçōes, e há necessidade de revisão e correções." (SIMON, 1970: 43-44)

A autora prossegue em seu relato com os seguintes indicativos:

"A possibilidade de se fazer da direção um trabalho de equipe, através do Conselho Técnico Administrativo (C.T.A.) que tem por função debater decisões a serem tomadas e montar programas integrados, assim como avaliá-los, nos parece uma atitude experimental válida, como trabalho de uma equipe multiprofissional. É neste aspecto que salientamos as vantagens da administração múltipla, conforme KOONTZ e O'DONNELL (10) (1962), principalmente no planejamento, que em etapas define objetivos e seleciona alternativas para atingir e medir 0 grau de sucesso obtido. A ação individual na direção expressa através da liderança é essencial no desempenho eficaz de uma equipe. $E$, no caso de uma comissão consultiva administrativa liderada positivamente, o controle, a coordenação e a execução se tornam mais fáceis e mais eficazes." (SIMON, 1970: 44)

As inovações, portanto, eram muitas e atingiam vários aspectos da formação da unidade sanitária. Iniciou-se com a novidade trazida pelo convênio entre uma instituição de ensino privada com o setor público, os trabalhos preliminares com a formação de uma equipe de pesquisadores que realizaram o censo na região, a inclusão de alunos nesse processo de investigação, a especificidade de uma carreira de médico sanitarista (e outras profissões, também) e, fundamentalmente a formação de uma equipe técnica atuando em conjunto com o médico sanitarista chefe da unidade. 
Neste processo de experimentação desencadeado por profissionais, atingia tanto questões mais conceituais e, portanto, reflexões no plano das concepções, como as questões práticas de organização da assistência, do ensino e da pesquisa, envolvendo ainda experimentos em administração, como relatado acima.

Importante, também, são as considerações de um dos professores entrevistados sobre o aspecto da inovação, considerando, primeiro, as ações em saúde baseadas no conhecimento sobre a realidade, além do deslocamento da responsabilidade por uma determinada área urbana e uma população para a unidade sanitária, como experiências importantes pelo seu valor instrumental e não somente um valor final (Entrevistado $n^{\circ} 18$ ). A unidade deveria demonstrar na prática como deveriam ser as ações em saúde, o seu planejamento, incluindo aí o conhecimento sobre a realidade, até a execução de seus programas de assistência e de ensino.

A autonomia administrativa é, portanto, um aspecto essencial a ser apontado na história de formação do centro de saúde experimental da Barra Funda. A liberdade para testar novos modelos, não só de atenção à saúde, mas também de formação de recursos humanos para a saúde, é um aspecto crucial em sua análise. Neste caso, uma autonomia com relação à instituição maior que a subordinava, como da instância da administração pública representada pela secretaria de estado da saúde de São Paulo.

A autonomia estava circunscrita à ação técnica da unidade. Isto é, as decisões tomadas quanto às ações de saúde, formação de recursos humanos e organização do ensino e da pesquisa, estavam sob o controle de um Conselho Diretor composto pelos seguintes membros: diretor da faculdade de Ciências Médicas da Santa Casa (o qual presidia o conselho), diretor do Departamento Regional de Saúde da Grande São Paulo, representante da mesa administrativa da Santa Casa de Misericórdia de São Paulo, professor-chefe do Departamento de Medicina Social da 
faculdade e representante do Grupo Setorial da Secretaria de Saúde Pública. (SES, 1970)

Quanto à organização interna, o comando das ações da unidade ficaram à cargo de um médico sanitarista ${ }^{10}$ Ficou estabelecida a seguinte hierarquia funcional: um médico sanitarista chefe estabelecia a unidade na organização. Vejamos as considerações de SIMON (1970) sobre este aspecto:

"Os integrantes da equipe staff passaram a ser distribuidos nos serviços que compunham a departamentalização básica do C.S.E.B.F., excetuandose a educadora de saúde pública que, pela natureza das suas funções, foi colocada em posição de assessoria ao médico-chefe da unidade sanitária.

Com o inicio das atividades, a equipe passou a enfrentar problemas bastante comuns a grupos profissionalmente heterogêneos, tais como, a definição de atribuições, os limites de atuação de cada profissional, as linhas de autoridade de cada serviço e destes com a chefia, e os entrosamentos necessários para um desempenho harmonioso das tarefas de cada um.

A filosofia de ação que norteou a firme direção do médico-sanitarista chefe da unidade foi aparando arestas e lapidando um só núcleo de trabalho e idéias. Esta filosofia, sedimentada sistematicamente através de debates e reuniōes, parece ter sido fundamentada em três diretrizes básicas, a saber:

- ninguém é mais competente em sua área de atuação que o próprio profissional;

- as áreas de atuação não são estanques, isto porque as necessidades do homem, da familia e da comunidade são globais e necessitam de soluções integradas;

- a integração dos serviços dos vários profissionais não deve ser feita em nivel teórico com a distribuição de áreas de atuação, mas a nivel prático, a partir das necessidades do homem, da família e da comunidade e em função das disponibilidades da equipe.

Esta política de ação, já no decorrer dos primeiros meses de funcionamento do C.S.E.B.F., levou o chefe a unidade sanitária a executar a direção de forma bastante descentralizada, procurando consultar com freqüência os membros da equipe de planejamento. Entretanto,

${ }^{10}$ O primeiro diretor técnico foi o doutor Otávio A. Mercadante. 
facilitado pelo entrosamento anterior, o já formado grupo passou a ter função regular de consultoria, reflexão e crítica sobre o trabalho do C.S.E. como um todo, e passou a se denominar Conselho Técnico-Administrativo (C.T.A.)." (SIMON, 1970: 22)

A composição do pessoal quando de sua formação era a seguinte: um médico-sanitarista chefe, cinco médicos consultantes, uma enfermeira de saúde pública chefe, duas enfermeiras de saúde pública, uma assistente social, um dentista, uma educadora de saúde pública, um contador, uma escriturária, três atendentes, três serventes, um auxiliar de higiene dental e um auxiliar social, somando um total de vinte e dois funcionários. Ao final do ano de 1969 o C.S.E.B.F. passou a contar com mais oito visitadoras de saúde pública. (SIMON, 1970: 22)

A distribuição deste funcionários foi efetivada seguindo a orientação dos programas de saúde ${ }^{11}$ desenvolvidos na unidade, além do próprio grupo de comando:

1) Chefia e administração: médico-sanitarista chefe, enfermeira de saúde pública chefe, chefe administrativo, educadora de saúde pública, contador, dois auxiliares administrativos, três serventes;

2) saúde do adulto: dois médicos, um atendente, uma enfermeira de saúde pública;

3) saúde da criança: dois médicos, uma atendente, uma enfermeira de saúde pública;

4) saúde materna: um médico, uma atendente, uma enfermeira de saúde pública;

5) serviço social: uma assistente social e um auxiliar social.

\footnotetext{
${ }^{11}$ Mercadante (1970) define da seguinte forma a organização dos serviços: "A unidade desenvolve os seguintes sub-programas que compõem o 'programa C.S.E.B.F.': chefia e administração; pré-natal; ginecologia e prevenção de cancer ginecológico, saúde da criança; saúde do escolar; saúde do adulto; vacinações; controle de tuberculose; saúde dental; aplicação tópica de fluor; visita domiciliar; serviço social; seleção e classificação sócio-econômica; epidemiologia e estatística; laboratório de saúde pública; ensino e treinamento." (MERCADANTE, 1970: 10-11)
} 
6) saúde dental: um dentista e um auxiliar de higiene dental;

7) controle de moléstias transmissiveis e vacinações: uma enfermeira de saúde pública e uma atendente. (SIMON, 1970: 24)

A assistência prestada pela unidade restringia-se aos moradores da área do subdistrito da Barra Funda e do Bom Retiro, que compreendia na época uma população de 26.500 habitantes num espaço geográfico de 2,5 $\mathrm{Km}^{2}$.

O esquema de matrícula era realizado em prontuários familiares, onde todos os membros componentes de uma familia tinham registradas suas passagens pela unidade. Esta forma de registro procurava dar cobertura a todos os problemas identificados na familia, possibilitando à equipe multiprofissional uma atuação mais segura porque amparada em informações sobre a realidade dos problemas de saúde de cada núcleo familiar ${ }^{12}$.

As pesquisas desenvolvidas pela unidade deveriam versar sobre temáticas diretamente voltadas para a prática dos serviços, constituindo por vezes a finalidade de serem estudos operacionais, voltados diretamente para a reflexão e mudança da prática, além de sempre constituírem modelos a serem seguidos pelo serviço público de saúde.

Outra importante finalidade do centro de saúde experimental da Barra Funda era seu caráter de promoção da saúde à comunidade, incentivando-a a procurar o serviço médico, além de instruí-la através de atividades educacionais programadas, tais como, orientações individuais (pré e pós-consulta do serviço de enfermagem), orientações em grupo (realizadas pela equipe de saúde), atendimento de grupos para terapia ocupacional, grupos de gestantes, orientações às mães e, também, alcoólatras. (MERCADANTE, 1970: 12)

As relações com a comunidade, aspecto fundamental em seus princípios organizacionais, foi enfatizada a medida que foram estruturadas 
as bases para esta aproximação: a formação de visitadoras de saúde pública e o estabelecimento de canais de comunicação com associações de bairro, ou outros grupos representativos dos interesses da população.

\title{
O ensino e a pesquisa
}

Fundamentalmente, são dois os aspectos importantes a serem observados na formação e na história do centro de saúde-escola da Barra Funda: primeiro, a especificidade, ou qualidade, de ser escola; e, segundo, o seu caráter experimental, atuando como laboratório de pesquisas, tanto para a organização dos serviços, como para orientar o ensino dentro de seus limites.

Vejamos o primeiro: o ensino dimensionado dentro do serviço. 0 primeiro aspecto a ser salientado é o afastamento do hospital como único e exclusivo meio institucional de ensino médico. São significativas as palavras de um dos entrevistados:

\begin{abstract}
"A primeira idéia era cumprir, fora do hospital, o ensino médico. Acho que a gente localiza isso na famosa conferência de Viña del Mar, da qual o dr. Leser participou, onde surgiram propostas para a renovação do ensino médico. $O$ enfoque naquele momento era o de que o médico deveria estar mais voltado à realidade social, deixando o enfoque excessivamente assistencial $e$ individual e incorporar uma visão do social e ao aluno caberia desenvolver habilidades de lidar não só com doentes em hospitais, mas com problemas prevalentes na realidade onde ele vai trabalhar. Acho que essa é a frase que consta em vários documentos: 'trabalhar com a realidade de saúde da comunidade, da população onde ele vai trabalhar'. Então, com essa idéia de Viña del Mar, surge uma série de departamentos de medicina preventiva. Primeiro é o de Ribeirão Preto, depois é o Leser, na Escola Paulista de Medicina. A grande preocupação era a de que o ensino médico não fosse
\end{abstract}

\footnotetext{
${ }^{12}$ Estaria presente nesta forma de controle dos registros e da conseqüente ação em saúde a concepção de homem em seus aspectos bio-psico-sociais.
} 
apenas dentro de uma enfermaria de hospital mas também se fizesse 'extra-muros'." (Entrevista $n^{\circ} 1$ )

As considerações anteriores são confirmadas por outro participante da formação e que até os dias atuais participa das atividades de ensino e pesquisa desenvolvidas no centro de saúde escola:

"(...) A idéia era de que se construísse um modelo a partir da própria realidade. Só que o olhar sobre a realidade era um olhar técnico sempre com a idéia de que você deveria partir com um olhar sobre a realidade.

Tem duas pontas nisso: de um lado, contemplar a realidade e partir dela; por outro lado, considerar que o técnico tem condições de captá-la. Mas não era somente essa a questão. Há outras questões sobre esse modelo. Havia, sim, uma certa disputa com o modelo clinico. Estavam tentando demonstrar que além da visão clínica individual, havia uma outra visão de saúde: a da coletividade. $E$ nesse sentido ele tinha uma inovação. (Entrevistado $n^{\circ} 18$ )

Há, portanto, que se considerar que ao estruturarem o centro de saúde experimental da Barra Funda, os profissionais envolvidos preocuparam-se, fundamentalmente, em assegurar um espaço diferenciado para o ensino, inovando não só com relação à organização dos serviços, mas empregando novas concepções em saúde que estavam sendo colocadas naquele momento. É significativo, neste sentido, 0 fato de que alguns trabalhos acadêmicos ${ }^{13}$ foram realizados naquele momento analisando o contexto de surgimento, a organização e suas finalidades perante os alunos do curso de medicina e a população da área de abrangência do centro de saúde.

Com relação ao ensino, a proposta era a de inserir os alunos de medicina nos serviços hospitalares, ambulatoriais e de comunidade, para

${ }^{13}$ Cf. Herrera, N.A., Serviço Social e Saúde Pública: Instalaçăo do Centro de Saúde Experimental da Barra Funda, dissertação de mestrado, 1969; Mercadante, O.A., Um Centro de Saúde como Local de Estágio de Saúde Pública para Estudantes de Medicina, dissertação de mestrado, 1970; e, Simon, U.M., O Centro de Saúde Experimental da Barra Funda, dissertação de mestrado, 1970. 
que os mesmos pudessem aprender "os procedimentos modernos de prevenção, diagnóstico e tratamento" (MERCADANTE, 1970: 4), ao mesmo tempo que seriam ensinados na prática a organização e funcionamento dos serviços de atenção médica integral às parcelas da população inseridas na área de abrangência delimitada. Neste sentido, o autor chama a atenção para a inserção da disciplina de Medicina Preventiva no contexto universitário entendendo-a da seguinte forma:

"a) o campo da medicina preventiva e social tem limites próprios, não devendo ser encarado como uma 'filosofia', mas como um campo de conhecimentos aplicados em diferentes niveis de ação do profissional, dentro do sistema de atenção médica; portanto, seu conteúdo procura influir na formação do aluno mediante a sua participação em açōes especificas fundamentadas num corpo teórico de informaçōes e concepçōes críticas;

b) o conteúdo do campo tenderia a ser preservado na medida em que as ações especificas de prestação de serviços de atenção médica sempre reservará à medicina preventiva e social um papel integrador, fundamentado em um corpo de conhecimentos e métodos próprios;

c) podem ser aceitos, preliminarmente, os objetivos definidos pelo Comitê de Expertos da OPS-OMS, acima citado, e que se resumem em:

objetivos quanto ao conhecimento e compreensão:

- dos métodos para o estudo do nivel de saúde coletiva e dos fatores ambientais, econômicos e sócio-culturais que modificam a saúde

- dos mecanismos para promover a saúde e prevenir a enfermidade e dos diversos sistemas de cuidado da saúde individual e coletiva

- dos determinantes da conduta no estado de saúde e enfermidade

objetivos quanto à incorporação da sequintes atitudes:

- atitude preventiva

- atitude epidemiológica

. atitude social

\footnotetext{
${ }^{14}$ Esta é uma referência do autor à polêmica gerada, na época, do conceito de medicina preventiva. Havia os que a entendiam como uma "filosofia" que deveria estar presente no ensino e na prática profissional de medicina, transmitindo a noção de que "prevenir é melhor do que curar". Ou seja, a finalidade dentro deste posicionamento era o de "formar a consciência" nos futuros profissionais.
} 
. atitude educativa e de equipe

objetivos quanto à aquisição de habilidades para:

- medir o nivel de saúde de uma comunidade levando em conta os fatores sócio-culturais e ambientais

- aplicar as diversas medidas de promoção da saúde

- cumprir o papel que corresponde ao médico na equipe de saúde

- conseguir o máximo de eficiência com o mesmo custo na prestação de serviços médicos." (MERCADANTE, 1970: 5-6)

O ensino não estava restrito aos alunos de medicina. Cursos de enfermagem, entre outros ${ }^{15}$, puderam estabelecer vínculos e mandar seus alunos para estágios que os colocassem dentro dos conhecimentos produzidos em saúde pública. As demais disciplinas ${ }^{16}$ do departamento de Medicina Social da Faculdade de Ciências Médicas da Santa Casa também estavam incluidas na programação geral de ensino estabelecida no centro de saúde.

Ensino e assistência estavam, portanto, conjugados numa mesma organização. Enquanto princípio, priorizaram a manutenção de um equilíbrio entre as "necessidades da comunidade e as necessidades de ensino e treinamento" (MERCADANTE, 1970: 13). Ordenaram os seguintes principios básicos que regessem os trabalhos sem comprometer, por um lado, 0 ensino ou a pesquisa, por outro lado:

“1) Nenhuma programação de atividades é feita somente para o ensino; portanto, o treinamento e o ensino devem estar sempre em função destas necessidades;

2) exigem-se condiçōes de continuidade a qualquer trabalho desenvolvido na comunidade, tanto pelos próprios alunos e docentes, ou então posteriormente, pela equipe de saúde;

3) limita-se a experimentação cientifica do Centro de Saúde Experimental ao campo da Saúde Pública, sendo

\footnotetext{
${ }^{15}$ Também foram estruturados estágios e cursos para alunos de Serviço Social, e alunos da Faculdade de Saúde Pública da USP,

16 As demais eram, naquele momento, Bioestatística, Ciências Sociais Aplicadas à Medicina, Medicina do Trabalho e Medicina Preventiva (epidemiologia, medicina preventiva das doenças transmissíveis e não-transmissiveis, ambulatório integrado e medicina domiciliar). (MERCADANTE, 1970: 3)
} 
a primeira prioridade as pesquisas operacionais." (MERCADANTE, 1970:13)

Estágios e treinamentos estavam portanto submetidos a normas que regulavam tanto a inserção de outros cursos de graduação no centro de saúde experimental da Barra Funda, como da permanência em seus limites sob o controle através de um planejamento - elaborado em conjunto com outras instituições interessadas e a equipe de saúde - no qual estariam estabelecidos critérios, tais como, objetivos pedagógicos, conteúdos teóricopráticos, métodos de ensino, requisitos mínimos exigidos, tempo de duração, horário e critérios de avaliação. Todos esses elementos seriam definidos após a verificação das reais "necessidades da comunidade, do centro de saúde experimental e da instituição maior em que estava inserido" (MERCADANTE, 1970: 14).

Pode-se perceber, portanto, que os critérios de escolha e elaboração de programas de ensino levavam em consideração prioritariamente a população assistida pelo serviço de saúde. Apesar de suas intenções com relação ao ensino consistirem em ponto fundamental de suas finalidades e de seu surgimento, permaneceu no projeto de formaçăo do centro de saúde experimental um sentido bem definido de que os cuidados destinados à população poderiam prestar-se ao ensino e à pesquisa, sem contudo serem determinados pelos interesses colocados por essas duas últimas finalidades. No tripé assistência-ensino-pesquisa, a subordinação das duas últimas fica claramente estabelecida a partir do entendimento da idéia de que a formação de um laboratório deveria conter a forma exata dos serviços públicos similares distribuidos pela rede de assistência à saúde do estado, o que criaria condições especiais de educação e uma expressão realista da população que estaria sendo atendida por um serviço estruturado nos moldes oficiais. Observemos a seguinte passagem da entrevista com um dos professores fundadores:

"O que é um centro de saúde? É uma unidade que atua numa determinada área delimitada, que atende com eixos 
programáticos de atuação a partir da realidade, do perfil das doenças da região e deve ter, também uma ênfase preventiva muito mais do que curativa. De prevenção e promoção de saúde. Ele deve ser dinâmico. Ele não fica esperando a clientela na demanda espontânea. Ele vai até a população, faz pesquisa domiciliar. Ele tem uma importância muito grande nos centros educativos e tem como unidade de trabalho o prontuário de familia.

(...) A gente analisa o centro de saúde enquanto, por um lado, inserido no quadro da medicina e das práticas médicas fora dos hospitais $e$, por outro lado, o centro de saúde enquanto unidade de saúde pública vinculada a uma determinada população, determinado território e aí, forma-se um laboratório mesmo, porque a chamada medicina preventiva ou medicina social, é uma disciplina básica. Surgiu dai a idéia de chamar isso de laboratório. Cada disciplina tem seu laboratório. O laboratório de saúde pública e medicina social é a comunidade. Daí surgiu essa idéia de usar a expressão de laboratório extra-mural." (Entrevistado $n^{\circ} 1$ )

A idéia de laboratório viria corroborar uma outra atividade dentro do centro de saúde experimental: a formação de pessoal especializado para atuar na rede de serviços públicos, além de servir à composição de seus próprios quadros.

\section{Treinamento em serviço}

Criado o espaço adequado ao atendimento e que respeitasse a organização da rede pública de serviços em saúde, seguindo seus critérios quanto à organização interna e aspectos técnicos definidos previamente, o centro de saúde experimental da Barra Funda também inaugurou uma nova função: o treinamento em serviço de pessoal para atuar em saúde.

Com relação à unidade, o principal objetivo era a criação de um corpo homogêneo de funcionários que viabilizasse um trabalho coordenado segundo os ensinamentos promovidos. Era um curso voltado para o pessoal auxiliar, treinando serventes, atendentes e visitadoras de saúde pública para a atuação nos serviços (MERCADANTE, 1970: 21). O fundamento do 
ensino para estes cargos, dentro da unidade, consistia na aplicação da noção de saúde pública, entendida como ciência que desenvolveria a promoção, a proteção e a recuperação da saúde, além da recuperação dos acometidos por agravos, tendo na atuação o objetivo de atingir a coletividade e motivar a população quanto aos cuidados com a saúde (MERCADANTE, 1970: 22).

A formação das visitadoras de saúde pública incluía o aprendizado necessário à atuação frente ao serviço de assistência médica, procedendo na atendimento à população através da pré e da pós-consulta. As orientaçōes aos pacientes, assim como prescriçōes, diagnósticos, considerações sobre alimentação, exames, coleta de material e medidas higiênicas, eram algumas de suas atribuições. Ainda: selecionar, planejar, efetuar e documentar as visitas domiciliares, tornando-se responsáveis por um setor dentro da área total de responsabilidade da unidade sanitária. A subordinação destas às enfermeiras ainda requeria a participação constante em reuniões, além da colaboração nos programas de saúde instituídos. (SIMON, 1970: 29)

As visitas domiciliares restringiam-se, naquele momento, ao acompanhamento de gestantes inscritas na unidade, sendo uma visita quando da matrícula e outra após o parto. A condição das gestantes foi considerada prioritária, merecendo, em seu início, prioridade. A partir de 1970 , as visitas domiciliares passam a ser registradas segundo a finalidade, ou seja, passam a ser enquadradas dentro dos sub-programas específicos, sendo registradas separadamente.

O pessoal aceito para a formação em visitadora de saúde pública tinha formação em nivel médio e a partir do treinamento oferecido passavam à condição de profissionais estratégicos dentro do centro de saúde experimental a medida que faziam o controle das ocorrências ou possibilidades de doenças na população, acompanhando nas residências os problemas de cada família. Consistiam, na verdade, nos profissionais responsáveis pelo contato com a população. 
"(...) O profissional de nível médio era estratégico. Foi dada muita importância a esse trabalho em seu início e as visitadoras já eram, às vezes, pessoas que tinham curso secundário ou eram professoras primárias que receberam um treinamento muito intenso para sua atividade. Se considerava que o trabalho dela era dentro do centro de saúde, mas era basicamente fora. Era o canal de ligação do centro de saúde com a população. Quem fazia o controle da população, o acompanhamento em casa e também podia trazer novas questōes para o centro de saúde. A idéia era a de que o máximo da atuação destas visitadoras ocorresse fora; que elas fossem a ponta de lança desse contato diário." (Entrevistado $n^{\circ} 18$ )

A inovação, dentro desta perspectiva, consistiu na ampliação das possibilidades de controle sanitário de uma dada região associando-se o olhar lançado pelas pesquisas à constante observação feita pelas visitadoras durante seus encontros com a população. A dinâmica de seu olhar superava o diagnóstico estático, o retrato realizado pela pesquisa, a medida em que podia proporcionar "um filme, o movimento dessa realidade" (Entrevistado $n^{\circ} 18$ ). A valorização destes profissionais, naquele momento, foi muito intensa, dando-se ènfase ao seu treinamento e entendendo-as como tendo um papel estratégico no serviço.

No final dos anos 70 , o papel das visitadoras perde sua força. Em meio a sucessivas crises financeiras, as visitas domiciliares foram perdendo seu papel estratégico. As atividades externas deixaram de ter importância e abre-se uma crise de identidade dentro do Centro de Saúde-Escola Barra Funda. O fato não só coincide, como tem relações diretas com a remoção de uma favela existente ao lado das instalações do centro de saúde, diminuindo o número de visitas e transferindo a atuação das visitadoras para o desenvolvimento de serviços internos. ${ }^{17}$

17 O centro de saúde experimental da Barra Funda iniciou suas atividades na rua Anhanguera, sendo mudado, logo em seguida, para as proximidades da marginal do rio Tietê, na rua Dr. Abrão Ribeiro, vizinho à favela Ordem e Progresso. 
Final dos anos 70: mudanças

Houve, portanto, um deslocamento das atividades das visitadoras, tornando-se, a partir de então, profissionais mais importantes nas atividades internas do que nas externas. Muda-se a visão, o olhar, a forma de abordar a realidade da população. A abordagem destes profissionais promovia conhecimentos precisos e importantes às definições internas da organização. Criava condições de se pensar o bairro com seus problemas sanitários e habitacionais, pensar sobre as familias em seu desenvolvimento e transformações, nos membros agregados às familias já matriculadas. Enfim, viabilizava orientações à população fora do espaço físico da unidade de saúde, além de constituirem um grupo de profissionais habilitadas à observação e interpretação das ocorrências que viessem agravar as condiçōes de saúde da população, com as condiçōes de existência material (habitação, infra-estrutura sanitária do bairro ou residência visitada, coleta de lixo urbano, etc.).

Em meados dos anos 70, o médico Alexandre Vranjac assume a direção do centro de saúde da Barra Funda. A inovação instalada naquele momento era a de instituir na organização do trabalho as mini-equipes. Há, portanto, um deslocamento do modelo anterior - das determinações colocadas pela reforma Leser, nos anos 60 , o qual previa uma centralização das decisões associada à descentralização das ações.

Na prática isto significou uma descentralização na administração interna do centro de saúde criando, através das mini-equipes, maior autonomia nas decisões de cada grupo de trabalho. Ou seja, as ações que deveriam ser tomadas, o controle da qualidade do serviço, enfim, caberia a cada equipe as determinações mais adequadas ao encaminhamento do serviço. As equipes passaram a pensar as suas próprias ações, cultivando uma certa autonomia até então inexistente na organização dos serviços de saúde. A participação dos membros de cada equipe, incluindo ai 0 deslocamento das visitadoras para as atividades internas no centro de 
saúde, promoveu uma transformação intensa nas relações internas entre os funcionários ao passo que criava condições de participação dos niveis até então excluidos dos processos decisórios.

O fato gerou controvérsias entre os funcionários. Um dos entrevistados, formado como visitador nas origens do centro de saúde, narra o seu espanto quanto à possibilidade de poder participar das decisões. A forma anterior na qual haviam sido cultivadas no que diz respeito à hierarquia estabelecida entre os profissionais, impedia-as, de certa forma, de uma participação mais intensa nas decisōes e no estabelecimento dos caminhos do trabalho. O poder, o mando, a voz de comando sempre ecoou dos níveis superiores - médicos e enfermeiras para os níveis médios de formação escolar, como é de se esperar. Acontece que o padrão estabelecido mantinha as formas rígidas estabelecidas para 0 comportamento das visitadoras que incluiam, inclusive, uma adequação comportamental nas dependências da unidade. Isto significou, na prática, o estabelecimento de uma distância entre os niveis hierárquicos colocada com muita precisão. (Entrevistado $\left.n^{\circ} 19\right)$

Por isso, as mini-equipes vieram inaugurar uma nova fase não só no plano administrativo, como também das relaçōes internas. As expressões utilizadas por professores e antigos funcionários para designar o médico diretor, dr. Alexandre Vranjac, são significativas no sentido de explicitarem a postura de um diretor que introduziu modificaçōes profundas na organização: "paizão", pessoa "muito querida", pessoa que "olhava por todos", pensava e atuava nos problemas pessoais dos funcionários.

Era outro o momento vivido pelos funcionários do centro de saúde da Barra Funda. A favela Ordem e Progresso recebia, até o final dos anos 70 , os serviços prestados pela unidade de saúde. Funcionários recordam e afirmam que a remoção da população que habitava aquela favela promoveu uma certa paralização nas atividades de trabalho. $O$ primeiro impacto foi o não cumprimento do seu papel principal e para o qual haviam sido treinadas as visitadoras: a observação e a intervenção externas 
à unidade. Iniciou-se um movimento de crise no trabalho. As visitadoras passaram a desenvolver uma atuação interna ao serviço, deixando o centro de saúde de cumprir, ao menos parcialmente, o importante papel de controlar com precisão as ocorrências que comprometiam a saúde da população.

A liderança inaugurada pelo médico Alexandre Vranjac promoveu mudanças no que diz respeito às formas de administração da unidade de saúde. A mudança foi possivel justamente pela tradição cultivada dentro dos limites da organização, e preconizada em seus primórdios, de constituir um espaço onde novas formas de organização dos serviços de saúde fossem experimentadas tornando-se, assim, uma fonte de novas idéias e práticas nos serviços as quais seriam oferecidas enquanto exemplos à rede pública oficial de cuidados à saúde da população. Se, por um lado, a liderança do dr. Vranjac configurava-se como uma liderança tradicional, no sentido de estabelecer relações de cunho pessoal e alicerçadas em laços paternalistas com os funcionários da unidade, segundo os próprios informantes, por outro lado, as inovaçōes no plano administrativo foram viabilizadas no sentido de iniciar o processo de descentralização interna da gestão do serviço. Era, sem dúvida alguma, uma concepção inovadora que se estabelecia naquele momento e que parecia não contrastar diretamente com as atitudes em nível pessoal que passaram a ser estabelecidas.

O processo desencadeado de descentralização pode ter ocorrido justamente pela conjunção desses dois elementos: um, de cunho tradicional cujos alicerces estavam sedimentados em relaçōes pessoais, estabelecendo um clima de participação e confiança entre direção da unidade e grupo de trabalhadores; outro, de promover e alimentar a participação dos funcionários através da criação de uma estrutura administrativa fragmentada em pequenas equipes multiprofissionais que decidiriam parte de seus problemas, compartilhando-os entre si e na instância da chefia, também. 
O contraste entre os dois aspectos é interessante de ser notado pelo paradoxo que o mesmo apresenta. $A$ inserção de novas práticas, muito provavelmente, foi possivel de ser realizada justamente pelo fato de que as mudanças internas na forma de estabelecimento das relações entre os profissionais atuou como elemento facilitador. Ou seja, ao ser cultivada a proximidade entre os funcionários, algumas barreiras rígidas foram rompidas como, por exemplo, aquela existente entre a chefia de enfermagem e as visitadoras de saúde pública. Ao romper com esta forma de organizar o pessoal integrado ao serviço, foi possível integrá-los de outra forma. Primeiro, pulverizando, através das mini-equipes, o poder dentro dos limites do centro de saúde, lançando aos funcionários as responsabilidades quanto às decisões e a responsabilidade pelas suas realizações nos serviços.

Outra inovação experimentada, ainda na administração do dr. Vranjac, foi a instalação dos serviços de homeopatia e saúde do trabalhador $^{18}$. Foram duas experiências inovadoras e que contribuíram para a manutenção dos objetivos e, principalmente, das práticas desenvolvidas dentro da unidade de saúde. O caráter experimental de sua atuação, previsto e ensejado em seu surgimento, parecia manter-se vivo, dando sentido à atuação de uma organização prestadora de serviços à população da área central da cidade de São Paulo, assim como oferecendo novas possibilidades ao ensino e à pesquisa desenvolvidos em seus limites. Com relação à experiência da inserção do serviço de homeopatia no centro de saúde, esta teve uma repercussão importante quando consolidada a aplicação de seu modelo no Inamps (Instituto Nacional de Assistência Médica e Previdência Social).

Durante os anos 80 , depois de uma sucessão de crises financeiras em sua história, teve inicio um periodo repleto de problemas que envolviam as ainda não resolvidas questões salariais - remunerações

\footnotetext{
${ }^{18}$ O serviço de homeopatia foi organizado pelo professor Mário Sposati e o de saúde do trabalhador pelo professor Morrone, ambos do departamento de Medicina Social da Faculdade de Ciências Médicas da Santa Casa de São Paulo.
} 
incompatíveis com as necessidades dos trabalhadores, atraso nos pagamentos, conflito permanente entre os administradores do dinheiro dos salários dos funcionários, a Fundação Arnaldo Vieira de Carvalho e diretoria do centro de saúde - que levaram o centro de saúde escola da Barra Funda a um periodo extremamente conturbado. Iniciava-se um conflito interno à fundação que identificava o centro de saúde como um setor, vinculado à organização do ensino custoso e cuja manutenção dependia da verba repassada pela secretaria estadual de saúde.

A crise não tinha sua explicação somente na questão financeira. Apesar de sua importância na manutenção daquele serviço, a crise tinha origem também na identidade que a organização tinha e deveria ter naquele momento. Os questionamentos colocavam em dúvida a sua existência, a importância de seu papel quanto ao ensino e mesmo à pesquisa, assim como dos vínculos com o departamento que o havia criado mas com o qual já não contava com uma participação mais intensa de seus docentes à frente de novas experiências que justificassem a importância e a continuidade dos trabalhos.

Com a entrada do professor Paulo Seixas na direção do centro de saúde $^{19}$, no início dos anos 90 , foi promovido um debate sobre os rumos que deveriam ser tomados. Realizaram um diagnóstico interno que viabilizasse o pensar aquela organização, mobilizando inclusive os funcionários que já estavam desanimados com as sucessivas crises e falta de uma orientação que previsse mais a longo prazo uma proposta concreta de projeto de centro de saúde-escola, além das necessárias definições sobre as questōes de financiamento sempre tão problemáticas.

Foi inaugurada uma outra fase nesse periodo. Após um pequeno período de mudanças com a saída do Dr Paulo Seixas, assume a direção do centro de saúde-escola o dr. Nivaldo Carneiro Jr., o qual já atuava

\footnotetext{
${ }^{19}$ A novidade, naquele momento, foi o estabelecimento de um grupo de estudos sobre saúde coletiva e a estruturação de uma administração a partir da formação de uma grupo de 8 funcionários que foi denominado de colegiado. A divisão no colegiado obedecia a separação em coordenações: administrativa, de ensino e de programas.
} 
anteriormente como médico. Tem início um processo articulado de aproximar as pessoas chamando a atenção para as dificuldades de natureza administrativo-financeira, assim como para as definições necessárias quanto ao papel do centro de saúde-escola perante a faculdade e perante a população de sua área de abrangência.

Teve início um processo de discussão dos rumos da unidade de saúde. Foram realizados seminários internos ao departamento, onde se discutiram questōes pertinentes ao centro de saúde com a participação de seus fundadores, dos quadros mais antigos de funcionários, assim como dos novos que articulavam a manutenção daquele serviço.

Nas palavras de um dos entrevistados, estes encontros serviram como momento de reflexão. à medida que propiciaram:

"Reconhecer a importáncia de darmos o passo juntos. A gente reconheceu que embora o grupo que lá estava fosse esforçado, ao olhar para o exterior ele fazia reavivar os que eram antes e depois. Quem era do projeto inicial, aqueles que eram depositários das idéias inicias do centro de saúde, de sua origem, que era representado pela dona Benedita, por exemplo, por todas as pessoas antigas. Visitadoras, como a Rosa, médicos como o Mercadante, o Seixas e o Guedes.

Por outro lado, um grupo jovem que tentava puxar mas não conseguia. Então, a gente achava que ali era uma forma da gente fazer uma certa catarse dos momentos, passando por esses processos e dizer: bom, isso não vai resolver. (...) Mostrar que a gente tem que passar por essas fases. Não desconsiderá-las.

Entender como são esses processos. Todos juntos. Antigos, novos e intermediários. Também não sabiam em que pé eles ficavam. Havia alguns que não sabiam em que pé ficavam. Eles não tinham nem projeto. Então, é muito dificil de dirigir uma instituição dessas. $A$ idéia era fazer essa passagem, contemplar aquilo, trazer esse processo e dar o passo.

(...) Talvez a grande saída seja olharmos juntos para essa realidade como tinha sido no começo. Olhar juntos a realidade e fazer uma proposta e a partir disso você envolve as pessoas num projeto.

Acho que teve muito dessa intenção. Por outro lado, celebrava de novo a relação do departamento pensando 
no centro de saúde como uma coisa importante." (Entrevistado $\left.n^{\circ} 18\right)$

A passagem para uma nova fase foi delimitada com a celebração através do encontro entre as várias gerações presentes no departamento e no centro de saúde-escola. Aos novos foram apresentadas além das concepções e ideais que nortearam a formação da unidade de saúde, um pouco de seu desenvolvimento histórico. Aos mais antigos e intermediários, reavivou-se as lembranças sobre os tempos em que de fato a qualidade de ser experimental era colocada à prova, seja na formação de seus quadros, seja nos programas instalados e concretizados.

A motivação encontrada pelo corpo de funcionários nessa experiência recuperou não só a auto-estima e o fortalecimento dos laços internos para a boa execução dos trabalhos através da consecução de um novo projeto. Foi fruto, sim, da própria dinâmica inaugurada e desenvolvida em seus limites: a característica de ser experimental. Aos novos foi possível demonstrar a consistência de um passado estruturado num projeto instituído sob as marcas do compromisso com a população e com o ensino de saúde pública. Essa força histórica, ora representada pelos professores, ora na de funcionários presentes desde a fundação do centro de saúde-escola, além de estar presente na reconstrução de seus rumos permanece em constantes intervenções através de projetos de ensino e pesquisa, ou mesmo nas orientações que os antigos mestres podem fornecer às novas gerações.

\section{O Centro de Saúde-Escola Barra Funda na atualidade}

Os anos 90 têm sido marcados por uma retomada das tendências originais propostas e executadas na formação da unidade de saúde, apesar das dificuldades que permanecem obstaculizando o bom desenvolvimento dos trabalhos. Não obstante, novos projetos estão sendo pensados e postos em prática na atualidade, o que coloca o centro de saúde-escola da Barra Funda novamente em conformidade com seus propósitos originais: 
experimentar novas formas da prática dos serviços de saúde, promovendo com isso o aprimoramento do ensino de graduação em medicina, além dos outros cursos, e da residência médica, nas dependências da unidade.

Segundo o documento ${ }^{20}$ produzido anualmente pela organização sobre as suas intenções e realizações para a manutenção do convênio com a Secretaria Estadual de Saúde do Estado de São Paulo, são os seus objetivos na atualidade:

"1 - Estabelecer as bases para a integração e cooperação da Universidade no Sistema Único de Saúde, no campo especifico da saúde coletiva.

2 - Estabelecer as bases para a realização de pesquisas de interesse do campo da saúde coletiva.

3 - Servir de campo de ensino e treinamento em serviço nas ações de saúde coletiva para alunos de graduação e pós-graduação.

4 - Servir como campo para a formação de quadros técnicos em nivel de especialização nas áreas pertinentes à saúde coletiva: vigilância epidemiológica, ações básicas de saúde, educação em saúde entre outras.

5 - Treinar pessoal técnico e auxiliar da rede pública de serviços na área de saúde coletiva.

6 - Desenvolver programas de educação continuada na área de saúde coletiva para os profissionais da rede de serviços.

7 - Desenvolver e avaliar os modelos e métodos para melhorar a assistência na área da saúde coletiva.

8 - Estabelecer mecanismos para a participação da população nas ações de saúde.

9 - Promover a prestaçăo de serviços de saúde à comunidade de forma integrada à rede de serviços regionalizada de saúde." (Centro de Saúde-Escola da Barra Funda, 1997)

Com relação à organização do trabalho na unidade, é importante ressaltar que a base administrativa de controle da clientela estava estruturada desde suas origens nos prontuários de familia, modo que, por um lado, facilitava o controle das auxiliares, enfermeiras e médicos nas

${ }^{20}$ Projeto Específico para o Ano de 1998, setembro de 1997. 
visitas a todos os membros da familia mas que, no decorrer do tempo, passou a trazer dificuldades no controle interno. Alguns aspectos indicados para a mudança desta forma de organização dos prontuários de família são: desdobramentos das famílias em outras famílias, a privacidade dos membros da família comprometida quando se tem acesso às informações de todas as pessoas numa só pasta durante uma consulta médica por algum dos membros familiares, além do necessário questionamento das categorias de chefe de família, companheira e filhos que em muitos casos não condizem com a realidade vivida pela população local.

Originalmente o prontuário de família objetivava um controle mais abrangente das condições de saúde da população. Mantinha como principal justificativa a garantia de uma visão total dos problemas de saúde da familia ao possibilitar aos agentes de saúde traçar o perfil familiar e localizar problemas anteriores, além de pensar possivveis relaçōes que explicassem não só os problemas do paciente presente à consulta médica como de qualquer outro procedimento na unidade de saúde. Cada funcionário da clínica que recebesse o prontuário verificava o retorno dos outros membros da familia ao serviço. Era uma forma de controle que em casos como o da saúde mental, por exemplo, o prontuário de familia era, e ainda é, um importante instrumento de informaçōes sobre o desenvolvimento das relações familiares facilitando o diagnóstico e encaminhamento do paciente o que, por outro lado, não significa que o prontuário individual não possa estar estruturado de forma a conter informações mais abrangentes, pelo menos no caso da saúde mental.

Neste sentido, foi elaborado um prontuário individual mas com uma numeração pertencente à família de origem. Neste caso, quando necessário, são requisitados os prontuários do restante dos familiares para que os funcionários do atendimento possam compor um quadro geral da familia. Estes casos são fundamentais quando da realização da ficha de 
matrícula - primeira consulta, quando o paciente deverá passar por uma triagem. $^{21}$

Os prontuários têm sido feitos individualmente, estando divididos em moradores e trabalhadores da região de abrangência. Há, também, a possibilidade das pessoas que chegam necessitando de cuidados mais urgentes e que mesmo não estando matriculadas, são atendidas na unidade. Neste caso, o setor de recepção e agendamento encaminha para a triagem, onde serão verificados os cuidados necessários àquele caso, deixando a matrícula ${ }^{22}$ do paciente para um outro dia. São denominados de pronto atendimento estes casos.

Com relação às atividades de assistência desenvolvidas com os moradores e trabalhadores já matriculados na unidade de saúde, são os seguintes procedimentos que são tomados quando as pessoas recorrem ao serviço: ao chegar passa pela recepção, denominada central de agendamento, onde têm sua ficha levantada $e$, também, são inquiridas sobre o que as levou até o serviço; dimensiona-se preliminarmente a situação de saúde, considerando-se duas possibilidades de encaminhamento: por um lado, se verificada a inexistência de qualquer sinal de adoecimento e constatado que o domicilio pertence a outra área, 0 funcionário encaminha o paciente para a unidade de seu bairro; se os indicativos expostos pela pessoa procedem na avaliação preliminar, a mesma é encaminhada para a central de enfermagem, onde as auxiliares irão colher toda a queixa exposta anteriormente e encaminhar para as enfermeiras ou para os médicos presentes na unidade naquele momento.

A central de enfermagem tem sua importância no que diz respeito a preparar o paciente para a consulta através da pré-consulta - momento de leitura das fichas, algumas perguntas rotineiras e levantamento de

\footnotetext{
${ }^{21}$ São cerca de 6 mil de familias cadastradas, com uma média de 5 pessoas por prontuário, totalizando aproximadamente $\mathbf{3 0}$ mil pessoas matriculadas na unidade de saúde.

${ }_{22}$ As matrículas somente são realizadas perante a apresentação de comprovante de domicilio ou trabalho na região e, nestes casos que são moradores de outras áreas, há uma matrícula com um número especial. Uma numeração que indique que o paciente habita foram da área.
} 
informações tais como, medidas de peso e de altura, febre, etc.; e a pósconsulta, momento em que as informações transmitidas pelos médicos em consulta são esclarecidas aos pacientes, seja nas consultas agendadas, seja nos atendimentos fora do agendamento.

Cabe às três enfermeiras da unidade a supervisão do fluxo do atendimento na central de enfermagem, cuidando ao mesmo tempo de impor maior agilidade no atendimento, assim como dirimir quaisquer dúvidas que porventura sejam levantadas pelas auxiliares. As enfermeiras cuidam de estabelecer um vínculo que não seja exclusivamente de controle sobre o trabalho das auxiliares; um vinculo que procura enfatizar a autonomia no trabalho das auxiliares, estimulando-as, muitas vezes, à tomada de decisōes individuais em casos menos complexos.

No caso de fichas novas que são preenchidas pela central de recepção, é realizado um controle denominado internamente de visitas domiciliares. Estas visitas consistem em identificar, primeiramente, a veracidade das informações transmitidas ao serviço quando da realização da matricula. Mas não é o seu objetivo principal. Pelo contrário, a visita domiciliar procura manter um processo de observação permanente das pessoas matriculadas na unidade, propriciando o levantamento de informações cruciais à manutenção e desenvolvimento da assistência na organização. Moradia, condições da habitação, ou a inserção na categoria de morador de rua que muitas vezes utiliza o endereço domiciliar de outras pessoas, vinculos e usos dos aparelhos públicos ou instituiçōes privadas na área, relações locais com a vizinhança, condições de infra-estrutura sanitária na rua, enfim, tudo aquilo que poderia contribuir enquanto informação preciosa a uma caracterização objetiva das condições de vida da população matriculada na unidade de saúde.

As visitas domiciliares estão inseridas no organograma (Anexo 1) do centro de saúde-escola Barra Funda dentro do Núcleo de Informação e Vigilància ${ }^{23}$ à saúde. A sua prática significa a possibilidade de que as açōes

\footnotetext{
${ }^{23}$ Projeto Específico para o Ano de 1998, setembro de 1997.
} 
promovidas pela unidade sejam avaliadas continuamente através da análise do impacto causado junto à população assistida. Os desdobramentos de suas informações devem servir, portanto, à atividade gerencial e ao planejamento das ações. São suas áreas operacionais: a vigilância à saúde, cujas ações decorrem da vigilância epidemiológica da região, sem manter a exclusividade para a notificação de doenças de notificação compulsória, mas identificando quaisquer agravos à saúde que interessem aos trabalhos desenvolvidos na unidade e segundo as necessidades de saúde da população - as visitas domiciliares têm sua importância justamente por poderem detectar casos tendo por prioridade os programas da tuberculose, hanseniase e câncer de colo uterino; a avaliação e controle do serviço, procura avaliar e controlar o cumprimento dos objetivos e metas dos programas desenvolvidos, além de controlar os aspetos administrativos controle de material, por exemplo; por fim, avaliação de saúde da população da região de abrangéncia, produção de relatórios cujas temáticas envolvam as condições de vida da população da região de abrangência e perfil epidemiológico, caracterizando, dessa forma, as necessidades de saúde locais.

As ações de saúde, por sua vez, constituem o corpo de atividades programadas desenvolvidas pela unidade. Configuram-se conforme as necessidades de saúde indicadas pelo núcleo de informação e vigilância, estruturadas tradicionalmente como áreas de atuação em saúde pública.

As ações desenvolvidas junto aos adultos incluem o tratamento de doenças crônico degenerativas, a atenção à saúde da mulher - pré-natal e puerpério, planejamento familiar, prevenção do câncer ginecológico e controle sobre as doenças sexualmente transmissiveis; saúde do trabalhador - vigilância das condições de trabalho, assistência médica aos acidentados em trabalho; atendimento clínico - consultas médicas de patologias não previstas e queixas agudas; atenção à saúde mental - grupo psicoterápico, grupos de mães, urgências; assistência domiciliar - 
assistência a domicilio de pessoas com dependência total ou parcial de auto-locomoção e auto-cuidado, cuidados especiais à domicilio, suporte psico-social; atenção à população adulta de rua - sistematizar o atendimento a este segmento, promovendo uma sensibilização dos funcionários da unidade para as questões sociais que envolvem os moradores de rua. Ainda com relação aos moradores de rua, a unidade busca conhecer o perfil daqueles que procuram o serviço de saúde, além de compor a necessária articulação com organizações não governamentais que atuam em benefício desta parcela da população. ${ }^{24}$

As açōes em saúde compreendem, também, os cuidados à saúde das crianças. Enquadradas nesta categoria, a unidade assiste crianças de 0 a 14 anos de idade, procurando identificar, primeiramente os recémnascidos de alto risco para o levantamento da taxas de morbi-mortalidade. Também está organizado o acompanhamento das crianças consideradas sadias - puericultura, constituindo neste sentido uma prática que não só orienta com também identifica a intercorrência de alterações no estado de saúde das crianças. A saúde da criança em idade escolar também faz parte das açōes promovidas pela unidade de saúde, consistindo tarefa importante junto às creches e escolas da região, além de promover a atenção à saúde bucal.

Dentre as atividades do centro de saúde, está incluída a atenção à saúde dos adolescentes, identificados entre os jovens na faixa dos 14 a 18 anos de idade. Estas ações procuram acompanhar os adolescentes identificando, problemas de desenvolvimento pondero-estatural e de amadurecimento sexual, além da cobertura de vacinas e cuidados com relação a doenças hematológicas, reumatológicas, doenças sexualmente transmissíveis, epilepsias, verminoses, alergias, alteraçōes cardíacas. Inclui um suporte terapêutico a pacientes e familiares.

${ }^{24}$ O centro de saúde-escola da Barra Funda participa do conjunto de organizações não governamentais denominado Fórum de Entidades e Serviços que Trabalham com a População Adulta de Rua. 
A atenção à saúde bucal também faz parte das atividades desenvolvidas pela unidade de saúde, objetivando, principalmente, o desenvolvimento de ações que visem a promoção, recuperação e manutenção da saúde oral, cuidando das ocorrências de doenças gengivais e, também, das cáries dentárias. Os grupos populacionais aos quais são dirigidas as açōes são: gestantes participando da assistência no pré-natal e crianças de 0 a 14 anos de idade. Eventualmente são realizadas consultas de emergência à população adulta da região.

Quanto ao serviço de enfermagem existente na unidade, este assume importante papel na estrutura da organização do serviço a medida em que abrange as dimensões administrativa e técnica do trabalho, constituindo num certo sentido a ponte que liga as necessidades básicas da organização e seu funcionamento à execução das suas finalidades de assistência, ensino e pesquisa. A equipe de enfermagem compreende 0 grupo de enfermeiras e o de auxiliares de enfermagem, compondo uma equipe que participa em todas as atividades desenvolvidas na unidade. Às enfermeiras cabe supervisionar e orientar as auxiliares em seu trabalho, assim como organizar processos administrativos, tais como, escala de folgas e férias de acordo com as necessidades de sua participação na programação cumprida pela unidade de saúde

Basicamente são estas as atividades de cuidados à saúde desenvolvidas pela unidade em sua área de abrangência. De forma complementar, é oferecido o apoio do pessoal de serviço social, aos quais cabe levantar e encaminhar os problemas de saúde da população local tendo em vista compreender e atuar sobre os mesmos considerando os seus componentes sociais, emocionais, culturais e econômicos. No âmbito da prática do serviço social, há o desenvolvimento de atendimentos individuais - casos, nos quais podem ser detectados os principais problemas de saúde da população em suas conexões com as outras questões que expliquem esses fenômenos e auxiliem mo encaminhamento das resoluções necessárias postas a serviço da clientela. 
Por fim, o setor administrativo fornece o suporte necessário quanto à realização das ações em saúde. Controle do atendimento direto ao público através da recepção, controle da organização dos prontuários no arquivo e uma secretaria administrativa para os encaminhamentos gerais e, especificamente, o de alunos, são suas principais atribuições.

Atualmente o Centro de Saúde-Escola Barra Funda conta com uma equipe profissional de 61 , conforma dados apresentados na tabela na pág 58.

A estrutura hierárquica é dirigida por um médico denominado diretor técnico, além de um médico supervisor que o acompanha no encaminhamento das atividades. Nesta estrutura administrativa há ênfase especial nas atividades pensadas e dirigidas pela equipe multiprofissional. Para isso, os funcionários são distribuidos da seguinte maneira:

- Diretoria técnica: comissão de creche, comissão de ética e pesquisa, comissão de ensino e núcleo de informação epidemiológica.

- Área administrativa: secretaria, arquivo central de agendamento e recepção, serviços gerais, almoxarifado e farmácia.

. Área de atenção à saúde: por um lado as açōes em saúde coletiva (adulto, adolescente, bucal, mulher, mental e criança); por outro lado, atendimento nas clínicas (pediatria, ginecologia e obstetrícia, psiquiatria, clinica médica, odontologia, serviço social e psicologia).

- Área de enfermagem: central de enfermagem, pré-consulta , pós-consulta, coleta de material, central de esterelização e vigilância epidemiológica. $(\text { Anexo I) })^{25}$

A atuação da unidade de saúde compreende uma área de abrangência que inclui parte dos distritos administrativos da Barra Funda, Bom Retiro e Santa Cecilia do Município de São Paulo, atuando para uma população de 32.739 habitantes, distribuídos por faixa etária da seguinte forma: de 0 a 19 anos $-25 \%$, de 20 a 49 anos - $50 \%$ e de 50 anos para cima $-25 \%$.

\footnotetext{
${ }^{25}$ Esta estrutura organizacional porposta pelo organograma, foi apresentada pela direção da unidade em reunião geral realizada em dezembro de 1997. (Anexo I)
} 
Com relação aos trabalhadores da área, estes giram em torno de 15 mil. Na distribuição por sexo, o feminino está à frente com 17.021, sendo o sexo masculino representado por 15.718. A renda média familiar dos habitantes da região está na faixa de 3 a 5 salários mínimos.

\section{O ensino e pesquisa}

As atividades de ensino desenvolvidas atualmente têm por objetivo maior sensibilizar o aluno de graduação ou de residência médica nas questões que cercam o conhecimento e a prática da assistência à saúde. São enfatizadas as discussões cujos temas básicos versam sobre as ações individuais e coletivas, tendo por suposto o conhecimento teórico e de pesquisa em epidemiologia como fundamentos para as discussōes desenvolvidas durante as atividades de ensino.

A postura presente na unidade de saúde, quando discutidas as questões do ensino, tem por princípio sempre privilegiar a assistência, colocando-a como ponto central das outras atividades de ensino e pesquisa. Tudo gira em torno da assistência, realidade que encontra-se em conformidade com os princípios colocados quando de sua fundação.

$\mathrm{Na}$ prática, o funcionamento da unidade não depende da organização do ensino. Mesmo assim, são comuns afirmações que considerem as intervençōes promovidas pelas atividades de ensino como quando, por exemplo, há resistência de alguns pacientes em serem assistidos por alunos nas consultas, fato comumente explicado pelo vínculo estabelecido entre médicos e pacientes na unidade. A questão aqui colocada ressalta a constante afirmação da qualidade do trabalho de assistência médica desenvolvida pelo serviço, o que acaba por gerar vínculos mais sólidos e duradouros entre pacientes e médicos, além de reforçar a concepção, entre os usuários, de atribuir qualidade ao atendimento pela confiança estabelecida entre as partes e, também, pela capacidade de resolução percebida no desempenho do pessoal do serviço. 
O ensino está voltado para as discussões sobre saúde pública, basicamente. Sem desconsiderar a prática da clínica, através da qual os casos podem ser discutidos entre alunos, professores e funcionários, 0 objetivo principal é o de ultrapassar a discussão do caso e alcançar suas implicações sociais, problematizando a prática médica através desta polaridade.

Passam pela unidade de saúde alunos do $3^{\circ}$ ano (disciplina de Pediatria Social), do $5^{\circ}$ ano (rodízio em Saúde Pública) e residentes do departamento de Medicina Social e de Pediatria da Faculdade de Ciências Médicas da Santa Casa de São Paulo; alunos dos curso de graduação em Fonoaudiologia, Serviço Social e Psicologia da Pontificia Universidade Católica de São Paulo e, também, alunos do curso de graduação em Enfermagem da Escola de Enfermagem Albert Einstein.

A estes alunos são oferecidas as possibilidades de conhecer as diferenças existentes entre $o$ atendimento hospitalar e aquele desenvolvido em unidade básica de saúde, considerando-se, pois, que o trabalho da equipe do centro de saúde deve entender o ensino como a possibilidade de colocar o aluno em contato com a comunidade a medida que as experiências vivenciadas, por exemplo, nas atividades de assistência domiciliar, proporcionam um contato diferenciado para $o$ alunado.

A pesquisa, por sua vez, configura-se como uma atividade ora voltada para a avaliação ou operacionalização das atividades assistenciais, ora voltada aos interesses dos docentes-pesquisadores do departamento de Medicina Social fornece orientação técnica à unidade.

Ficou evidenciado a ausência de uma estrutura que forneça suporte à produção de pesquisas na unidade. Há, dentre os membros da equipe de profissionais com formação superior, alguns que têm formação e experiência em trabalhos de pesquisa, mas que mesmo assim ressentem-se da falta de uma hierarquia que subordine as investigaçōes, orientando metodologicamente e ajudando a construir as linhas de pesquisa. Não obstante, a intencionalidade com relação a este tipo de atividade é 
facilmente percebida entre os membros componentes da equipe técnica, ressaltando-se a importancia da mesma no conjunto das atividades desenvolvidas como, também, o retorno que este conhecimento produzido em seus limites propicia em termos de reflexão da prática.

A pesquisa, dentro dessa ótica, assume o papel de sempre prover o serviço da possibilidade de pensar e atuar, quando necessário, de formas diferenciadas. 


\section{CAPÍTULO 4 - ANÁLISE DAS ENTREVISTAS JUNTO AOS FUNCIONÁRIOS}

Este capitulo foi organizado a partir da divisão existente entre as categorias profissionais envolvidas no serviço. Foram utilizadas informações obtidas através das entrevistas semi-estruturadas, assim como também foram valiosas as informaçōes muitas vezes coletadas espontaneamente durante encontros casuais ou conversas informais. Também contribuiram os registros feitos durante as reuniōes gerais com a participação dos funcionários.

A análise dos dados teve por orientação alguns questionamentos que forneceram os caminhos para a construção de um pensamento que pudesse explicar as relaçōes estabelecidas dentro da organização. Foram levantados, junto aos informantes, as concepçōes presentes sobre as atividades desenvolvidas junto aos usuários e aos alunos, a possibilidade de coexistência entre concepçōes antigas e novas, relaçōes entre funcionários antigos com os mais novos mediadas por experiências e concepçōes distintas, além do levantamento de consideraçōes sobre a produçăo da assistência, do ensino e da pesquisa.

A apresentação do capitulo segue da discussão sobre as consideraçōes do pessoal administrativo, identificando a sua importância na organização de todo o serviço desde a recepção dos usuários, até as questōes de ordem administrativa que impliquem em controle de material e da rotina do serviço.

Em seguida, são apresentadas as análises realizadas junto às auxiliares de enfermagem. Foram consideradas na análise algumas das funcionárias do setor administrativo pela antiga formação e atuação como visitadoras anteriormente exercidas na unidade nos serviços de saúde prestados à população. Procurou-se identificar, através de suas concepçōes sobre o trabalho em saúde e a especificidade do serviço, o papel destas 
auxiliares não só com relação às atividades assistenciais, mas, fundamentalmente os seus vínculos estabelecidos junto à população que utiliza o Centro de Saúde-Escola. A experiência de algumas funcionárias na unidade ultrapassa duas décadas de atuação, fato que muito contribuiu para a coleta dos dados e a conseqüente análise dela derivada.

As enfermeiras constituem, também, um bloco isolado de análise pelas peculiaridades na sua participação nas atividades desenvolvidas na unidade. Compõem, na verdade, um grupo com participação intensa em quase todos os setores da atividade assistencial, nos grupos de reflexão geralmente organizados como grupos de estudos, nas pesquisas realizadas na unidade, além da participação na organização do ensino na unidade.

As consideraçōes sobre as concepções das assistentes sociais entrevistadas são apresentadas fundamentais, pois o contato com os usuários visa promover um trabalho integrado à assistência médica. Cada profissional, dentro das suas especificidades de formação e atuação, pôde contribuir com consideraçōes valiosas à compreensāo do papel da assistência social na unidade, assim como das atividades desenvolvidas pela psicóloga junto à clientela e, também, nas suas contribuições na organização interna do serviço.

Por fim, as entrevistas com os médicos foram analisadas enquanto categoria profissional de destaque dentro da unidade não só pela atividade assistencial que lhes cabe oficialmente mas, também, pela exclusividade da profissão em ocupar o cargo de diretor da unidade de saúde desde os tempos de sua fundação. 


\section{1 - AS AUXILIARES}

O pessoal de nivel médio que atua na unidade de saúde, conta com a participação de antigas funcionárias em seus quadros. Outro aspecto fundamental é o de que o pessoal administrativo conta com funcionários com formaçāo e experiência anteriores como visitadoras e, também, como auxiliares de serviço social. Estas são características que as tornam funcionárias com uma experiência diferenciada não só pelo tempo de permanência, mas pela interação interna promovida entre as gerações de funcionários no decorrer de sua história.

Primeiramente, serão apresentadas algumas consideraçōes sobre o setor administrativo e a sua abrangência na atuação do serviço como um todo. Em seguida, serão discutidas as informaçōes levantadas junto às auxiliares de enfermagem que atuam diretamente na assistência.

$\mathrm{Na}$ análise das informações coletadas, procurou-se cercar aspectos cruciais às intençōes de investigação, tais como, controle do trabalho, relaçōes entre categorias profissionais e postos hierárquicos, convivência entre novas e antigas concepções, aprendizado no trabalho, o trabalho junto à população e as concepçōes que dão sentido à sua realização, além do ensino e da pesquisa realizados na unidade.

\section{Setor administrativo: porta de entrada da unidade}

O controle administrativo exercido pelos funcionários deste setor compreende, além das atribuiçōes mais comuns como administração dos recursos financeiros e de recursos humanos, a organização da entrada da clientela na unidade. A chegada de uma pessoa à unidade obedece uma rotina que envolve funcionários capacitados a ouvir e compreender as queixas expostas pela clientela. Isto porque são em sua maioria funcionários que tiveram em sua trajetória profissional formação técnica para o exercício das atividades de visitadora em saúde dentro da própria unidade. Há, também, aquelas que têm passagem pelo 
setor de serviço social, obtendo neste posto experiência com relação ao encaminhamento da clientela para a obtenção de documentaçăo de identidade, instituições que abriguem parcelas da população sem habitação ou em situação de migração, ou ainda trabalhando como divulgadoras das instituições sociais disponiveis à população mas nem sempre conhecidas.

Pode-se depreender desta situação que o esquema de controle, incluindo a recepção, triagem e resolução dos problemas da clientela, tem sua concepção e prática orientados por funcionários com experiência na unidade. Conhecedores, inclusive, de boa parte da população que freqüenta a unidade. Um conhecimento tanto em sua significação mais geral, como quando identificam as origens sócioeconômicas dos clientes, ou quando demonstram conhecer pessoalmente os usuários do serviço.

Esta experiência constitui um aspecto importante da análise, já que demonstra através da trajetória destes funcionários, a variedade de atividades pelas quais passaram e 0 aprendizado que nelas obtiveram, tanto no aspecto formal realizado através de cursos dentro e fora da unidade, como pela experiência adquirida nos postos que ocuparam dentro da própria unidade.

Acrescente-se a esta particularidade uma outra: o tempo de permanência de algumas funcionárias de nivel médio na unidade é longo. A mais nova das entrevistadas conta com dez anos de trabalho na unidade.

Esta experiência possibilita a essas profissionais uma atuação diferenciada, já que o conhecimento e a prática acumulados nas atuações na assistência à população amplia a visão sobre o trabalho, podendo refletir tanto sobre os aspectos técnicos da assistência e dos problemas administrativos decorrentes desta prática, como das questões sociais das quais derivam os problemas de saúde da população.

\section{As auxiliares, antigas visitadoras}

Ao ser recuperada a história da formação do centro de saúde-escola da Barra Funda, uma das evidências mais marcantes em suas origens talvez seja a 
prática de formar seus próprios quadros profissionais de nivel médio, identificando-os com um projeto particular de organização do serviço sob o enfoque da saúde pública.

As informaçōes coletadas junto às visitadoras foram organizadas tendo em vista discutir as seguintes indagaçōes que foram sendo elaboradas durante 0 processo de pesquisa: como convivem antigas e novas concepções e práticas de trabalho já que permanecem em seu quadro funcionárias formadas nos tempos de fundação da unidade de saúde? Quais as principais modificações em termos de relações hierárquicas entre os profissionais e o controle do trabalho? Como ocorre a aprendizagem no trabalho, além daquela recebida na formação inicial?

A forma de inserção das auxiliares na unidade de saúde ocorre, em todos os casos entrevistados, através, primeiramente, de um contato informal realizado com pessoas conhecidas que ou trabalhavam na unidade, ou conheciam quem trabalhava na unidade. Em todos os casos, fossem amigos ou parentes, as informações sobre a existência de vaga e de um processo seletivo para conseguir o cargo eram obtidas pelas vias do contato entre as pessoas.

Após a seleção, aquelas aprovadas eram inseridas no processo de ensino, o qual qualificava-as dentro de uma programação que incluia conteúdos especificos em saúde, assim como ao treinamento de habilidades técnicas, tais como, aplicação de vacinas, realização de curativos, etc.

Há, portanto, no fato de ter sido construída uma rede informal de contatos, uma particularidade imposta à divulgação das seleçōes públicas realizadas. A sua exclusão da rede oficial de centros de saúde pertencentes à administração pública estadual, permitia esta alternativa, a qual, por sua vez, não excluia o caráter público de seu processo de seleção mas, pelo contrário, possibilitava experimentar um movimento muito particular de articulação entre funcionários já treinados na organização, no contato com familiares e amigos, por exemplo, permitindo muito provavelmente explanações mais precisas sobre as finalidades do centro de saúde-escola, as suas funçōes e outras informações pertinentes ao serviço. Enfim, a divulgação das informaçōes teria sido difundida dentro de um âmbito restrito que incluía, obviamente, pessoas que necessitavam de 
um emprego, mas que também mantinham alguma proximidade com aqueles que divulgavam.

Por não possuirem uma formação anterior na área da saúde, a aprendizagem da profissão, enquanto parte da trajetória de cada profissional dentro da organização, é um marco importante, tendo sido evidenciado por todas as entrevistadas. Neste caso, a noção das atribuições da ocupação de auxiliares incorporaria elementos diferenciados das habilidades técnicas e dos conhecimentos teóricos. Era uma experiência que não supunha somente o aprendizado de conhecimentos, técnicas e habilidades, mas, fundamentalmente, a inserção de funcionários numa organização que tem por finalidade maior a assistência aos moradores da área de abrangência da unidade. Há algumas citaçōes, inclusive, que indicam esta valorização do cuidado com o ser humano como algo basal na formação profissional que tiveram e, por isso mesmo, anterior ao aprendizado de conhecimentos, técnicas e habilidades. Neste sentido, torna-se clara a presença de um valor maior que deposita no cuidado com o humano a sua expressão e prática. Um cuidado que, antes de se constituir enquanto conjunto de conhecimentos teóricos e técnicas à disposição da população, configura-se como uma valorização da vida humana. A seguinte passagem transcrita exemplifica e elucida bem as consideraçōes anteriores:

"Para mim foi ótima a formação porque eu não tinha noçāo de nada. Foi uma lição de vida. (...) Você aprende tudo isso; aprende a lidar com as pessoas, vocè vê o sofrimento das pessoas, você aprende a cuidar do ferimento. Então, além de você ajudar você está se ajudando, também." (Entrevistado $n^{\circ}$ 9)

Há, também, as que consideram que mesmo não gostando da área de saúde, quando da inserçāo na unidade e tendo recorrido ao emprego por necessidade financeira, acabaram gostando e achando muito bom poder aprender no trabalho a lidar com as pessoas.

Basicamente a formação dessas era composta de ensinamentos técnicos que as habilitava à vacinação, coleta de exames, realização de curativos, pré e pósconsulta, além de outras atividades. Por não exigir experiência anterior de trabalho 
em saúde, essa formação dentro do centro de saúde mantinha mais dois objetivos básicos: primeiro, instrumentalizar teórica e tecnicamente; segundo, cultivar pessoas que ainda não tivessem uma profissão encaminhada.

A extensão dessa formação ocorria conforme as novas funcionárias fossem sendo incluidas nas atividades de trabalho. Era comum, por exemplo, o acompanhamento das chamadas novatas pelas funcionárias já integradas ao trabalho. A participação de funcionários mais antigos nesta atividade de ensino junto aos novos, contribuia para a continuidade da aprendizagem desses funcionários mais antigos à medida em que eram obrigados a, por exemplo, preparar aulas e ministrá-las às novatas, conforme explicitado a seguir:

\begin{abstract}
"A gente aprendia com o pessoal que já trabalhava. Sempre tinha uma atendente mais antiga da casa. Nós éramos colocadas juntas e aprendiamos com ela. Quando tinha gente nova nós participávamos, também. Eu cheguei a dar uma aula. Uma aulinha e passar aquilo que eu tinha aprendido. Dei uma aula sobre temperatura." (Entrevistado $n^{\circ} 13$ )
\end{abstract}

Esses momentos estão marcados na memória das entrevistadas e são relatados como passagens de grandes emoções e de sedimentação da aprendizagem que obtiveram na unidade. São enfáticas ao atribuirem a estes momentos um significado especial, já que não estavam limitados somente à execução de seminários às novatas, mas como prova de que a inserção no serviço através da formação obtida internamente requeria um grau de compromisso maior do que somente executar as principais atribuiçōes do cargo: a prática da assistência e as visitas domiciliares. Era um momento de passagem tanto das que já estavam atuando no serviço, como daquelas que estavam sendo inseridas.

O ritual estava configurado no preparo e na apresentação, às novas colegas, da aula sobre um determinado assunto (doença, forma de contágio, conceitos, etc.). A passagem significava, às primeiras, a confirmação do conhecimento obtido e posto em prática no trabalho e, também, através das atividades didáticas desenvolvidas; às que entravam, a demonstração do nivel de compromisso que deveriam assumir na organização e as garantias de que a 
dinâmica do trabalho requeria um envolvimento maior do que somente a execução das funçōes previstas pelo cargo assumido.

Esta participação acabava por fazer a manutenção do elo entre as geraçōes de auxiliares. Mais do que compreendê-la como sendo unicamente uma transmissora de conhecimentos práticos e teóricos, em sua essência, este contato entre geraçōes de funcionários articulava-as dentro da organização e de suas finalidades, demonstrando uma prática de trabalho em saúde associada à reflexão promovida nāo só em sua execução, mas programando atividades de ensino que demonstrassem esta mesma prática em sua dimensão teórica.

Por outro lado, há um valor fundamental presente na fala dos entrevistados: o cuidado com o sofrimento do ser humano. Esta aproximação com o humano que sofre ocorreria através de uma intervençāo cuja finalidade seria a de oferecer apoio psicológico, além das intervençōes técnicas já destacadas anteriormente. Os pacientes podem, portanto, ser "bem recebidos e tranqüilizados". Atitudes como "bater um papo" são entendidas como ir além das atribuiçōes técnicas exigidas pelo cargo. "Procuro bater um papo fora do que estou fazendo; ser mais amiga". Da mesma funcionária entrevistada, pode-se destacar a seguinte passagem: "Além de você ajudar, você está se ajudando, também" (Entrevistado $n^{\circ}$ 9). Ou seja, a atividade não separa o elemento emocional na relação com os pacientes. Pelo contrário, o mesmo é colocado como elemento fundamental dentro do processo de trabalho, terminando por complementar as intervençōes técnicas.

O bom atendimento, para estas auxiliares, é aquele que faz com que o paciente retorne ao serviço de saúde, seja pelo restabelecimento de sua saúde, seja pela referência que as auxiliares acabam por promover motivando-os a construir um olhar sobre o serviço, bem sintetizado na seguinte passagem transcrita a seguir: "Atender o pessoal naquilo que eles precisam" (Entrevistado $n^{\circ} 10$ ), frase que traz um duplo sentido: por um lado, o possivel restabelecimento ou a prevenção às doenças e, por outro lado, estaria embutida a idéia de que a proximidade destas auxiliares com os pacientes possibilitaria captar a particularidade de cada pessoa, não observando somente o problema de saúde em si, mas o sofrimento dessas pessoas e sua relação com os outros problemas particulares em suas vidas. 
Este envolvimento com os clientes da unidade de saúde conta ainda com outra argumentação: a conquista do paciente. "Se ele (paciente) não se sentir seguro de contar a você o que ele não contou ao médico, a gente vai perder esse paciente $^{n}$ (Entrevistado $n^{\circ} 6$ ). Da mesma entrevista vem a idéia de "adoção" de alguns clientes enquanto prática comum entre as auxiliares. Uma prática que conjuga a técnica com uma postura de cultivar a proximidade com a clientela do serviço, chamando-a a participar de algo que pode ser benéfico tanto na dimensão do controle da saúde individual, como pelo amparo muitas vezes proporcionado à população que procura o serviço. ${ }^{1}$

Ao indicarem uma proximidade com a clientela do centro de saúdeescola, além de expressarem esta idéia enquanto componente essencial do trabalho em unidade básica de saúde, incluem uma concepção de centro de saúde. A proximidade com os usuários objetiva a criação de um vínculo que, por sua vez, abre caminho para um aprendizado, por parte da clientela, das reais intenções de um centro de saúde. "A gente tinha que ensinar para o cliente que não era para vir ao centro de saúde só quando ele precisasse, mas que o objetivo do centro de saúde era o de prevenir as doenças. A gente queria que eles viessem quando estivessem sadios, para prevenir." (Entrevistado $n^{\circ} 15$ )

Há, portanto, nas afirmaçōes de "atender bem o público" e "manter o público satisfeito" (Entrevistado $n^{\circ} 9$ ) uma tendência clara de que os serviços prestados pela unidade de saúde visam exclusivamente atender às necessidade da população. Além do cumprimento deste objetivo básico do centro de saúde-escola, há três marcas, segundo as auxiliares, que o diferencia dos demais: a qualidade de ser um centro de saúde que também recebe alunos; não pertencer ao setor estatal de prestação de serviços em saúde, desde a sua origem, e seguir orientaçōes administrativas rígidas por parte dos diretores que por lá passaram. São três aspectos que o diferenciam de um centro de saúde comum da rede de serviços em

\footnotetext{
${ }^{1}$ Durante o processo de coleta de dados da pesquisa obtive a informação de algumas funcionárias que uma das auxiliares mais antigas da unidade possuía muitos afilhados na regiāo. Algumas clientes atendidas durante a gestação ofereceram seus filhos aos seus cuidados espirituais escolhendo-a como madrinha de batismo. A prática, que denota a profundidade do vinculo estabelecido, atinge um grau significativo de importância dentro da tradição cristã dos cuidados com a evolução espiritual das crianças, demonstrando os laços entre algumas funcionárias e a clientela.
} 
saúde e que, por conseguinte, possibilitam a realização de um trabalho mais eficiente, ao mesmo tempo prazeroso porque realizador do objetivo básico da unidade: a satisfaçāo do usuário do serviço.

Com relação à população que freqüenta o CS na atualidade e em sua história, a visão que as auxiliares têm não descartam descriçōes por vezes pormenorizadas das modificaçōes ocorridas na área. Entram nas descrições consideraçōes como modificação do espaço urbano e tipos de habitação predominantes, demonstrando a relação existente entre condiçōes de vida da população e problemas de saúde dai derivados.

A primeira evidència apontada é a da transformaçāo da regiāo de uma população habitante de espaços denominados de favelas para as casas transformadas em cortiços, no decorrer dos anos, que passaram a abrigar um número muito grande de familias e pessoas agregadas.

"O pessoal da favela era muito peculiar. Eles procuravam mais o centro de saúde com vários problemas: dos mais graves aos mais leves. Muita gente com ferimentos graves, vários tipos de problemas como estupros, etc. Isso ai foi mudando, acabando. Ai começou a aparecer o pessoal com menos problemas. Um pessoal mais tranqüilo que vinha mais para o controle de saúde e dificilmente vinha 'caindo aos pedaços'. Na favela tinha gente com feridas feias, toda cheia de bicho e ai isso mudou." (Entrevistado $\left.n^{\circ} 19\right)$

O processo de mudança da constituição do espaço urbano na região da Barra Funda sofreu transformações no decorrer destas três décadas desde a fundação do Centro de Saúde-Escola. Era uma área da cidade composta por um elevado contingente populacional que habitava em favelas. Consequentemente, era um grupo mais suscetível aos agravos à saúde, considerando-se as precárias condiçōes de habitação e mesmo a ausência de infra-estrutura sanitária nos espaços das favelas.

Em seu principio de funcionamento, a unidade de saúde ocupava-se de conhecer toda a área de sua responsabilidade, dando importância a todos os segmentos da populaçāo presentes. Em especial, os grupos populacionais de favelados recebiam atenção da organização do serviço, cabendo às visitadoras - 
formadas dentro da unidade - o conhecimento das favelas, caracterizando-as através de registros que indicassem as condiçōes materiais observadas (moradia, pavimentação, coleta de lixo, etc.), assim como a busca de uma aproximação com as familias que habitavam aqueles espaços.

Esta aproximação com a população local implicava em dois aspectos básicos priorizados pela organização do serviço naquele momento: primeiro, matricular as familias e seus componentes na unidade de saúde tendo por finalidade mantê-las dentro da rotina do serviço de forma regular; segundo, instruir a população local sobre a importância do controle preventivo dos processos de adoecimento. Isto significava para as visitadoras um trabalho de conquista da população. A aproximação com as familias ia se constituindo com as visitas $e$, posteriormente, com a ida da população à unidade de saúde para a realização da matrícula seguida dos controles executados pelos profissionais em saúde.

Sob este aspecto, as considerações das entrevistadas versam sobre dois pontos: por um lado, as mudanças no perfil da população com a saida da populaçāo que habitava as favelas manteve dentro da unidade grupos populacionais com renda e nivel de escolaridade mais elevados, fato reconhecido como um "problema" já que quando trabalhavam com os "mais humildes" a relação profissional de saúdeclientela era "mais" fácil de ser realizada. Segundo uma das entrevistadas: "a população local foi mudando. $O$ trabalho foi mudando porque trabalhar com 0 pessoal mais humilde é mais fácil. O pessoal humilde te acata melhor. Tudo o que você fala eles ouvem. As orientaçōes são acatadas." (Entrevistado $n^{\circ} 15$ )

As diferenças sociais, portanto, mantinham uma espécie de regulação da execução do trabalho, ora facilitando pela ausência de instrução das familias mais empobrecidas, ora dificultando ao aumentar os agravos à saúde pela precariedade das condiçōes materiais de existência destas pessoas. A ambigüidade presente na fala destas funcionárias expressa, por um lado, a aproximação afetiva com a população por vezes encontrada sobreposta à realização efetiva das atividades de trabalho. Por exemplo, mesmo lidando com a precariedade das condiçōes de vida dos favelados, por vezes sem atingir resultados satisfatórios, ainda assim as relaçōes eram consideradas como tendo um grau mais baixo de conflitos. 
Ao valorizarem o próprio trabalho desenvolvido na unidade, estas auxiliares acabam por indicar os vínculos que foram sendo estabelecidos com a clientela. "Nossos clientes têm uma ligação com a gente. Tem muitos clientes que saem e vão morar longe, mas continuam vindo aqui porque percebem que o atendimento é diferenciado." (Entrevistado $n^{\circ} 13$ )

As visitas, portanto, configuravam-se como estratégia central no trabalho desenvolvido pela unidade. Eram verificadas as pessoas que não retornavam à unidade mesmo tendo sido matriculadas anteriormente. Era uma atividade de trabalho valorizada não só pelas funcionárias que a realizavam como pela populaçāo assistida pelo Centro de Saúde-Escola.

"Nas visitas procurávamos o entrosamento do Centro de SaúdeEscola com a população. Era para facilitar a comunicação, fazer com que eles tivessem mais confiança no trabalho da gente. Para a gente conseguir trabalhar com a comunidade com mais facilidade.

(...) Nós atingiamos; nós conseguiamos. O Centro de SaúdeEscola da Barra Funda era bem 'mãezona' mesmo. Tudo o que o pessoal queria resolver, eles procuravam o Centro de Saúde." (Entrevistado $\left.n^{\circ} 19\right)$

As mudanças promovidas internamente em decorrência das alterações do perfil da clientela assistida na unidade foram significativas no que diz respeito tanto ao esquema de trabalho adotado anteriormente, como as relações internas que assumiram uma outra configuração.

Primeiro, em seus primeiros anos o centro de saúde-escola obedecia a um esquema rigido de controle do trabalho, tendo nas enfermeiras o suporte essencial deste controle. Segundo os depoimentos coletados com as auxiliares mais antigas, a rigidez no trabalho tinha implicações não só na definição e execução de sua rotina, mas também na exigência de um comportamento pessoal tido como o melhor dentro da unidade.

A uniformidade na rotina estabelecida para o trabalho seguia sempre no mesmo ritmo, nunca sendo alterada por livre e espontânea vontade das auxiliares sem antes consultar as enfermeiras. $O$ depoimento apresentado a seguir evidencia bem esta questão: 
"Era rotina para tudo. Se nós iamos trabalhar no programa de saúde do adulto, estabelecia-se a rotina daquele atendimento. Criava-se a uniformidade. Depois ninguém precisava falar com ninguém porque a 'língua' era a mesma para todos. Todos já se entendiam.

A população chegava e era feita a matrícula, encaminhada à saúde do adulto, feita a pré-consulta, consulta e pós-consulta. Então, a pessoa recém matriculada já passava com a visitadora e esta encaminhava para exames de sangue e agendava a consulta seguinte. (...) Se não houvesse patologia alguma, tudo bem. Dai um ano ele voltava e fazia exames novamente. Agora se aparecesse alguma patologia ele já era encaminhado para a solução daquele problema.

(...) Cada programa tinha sua rotina. Saúde materna tinha sua rotina, tinha os exames de rotina e a rotina dos atendimentos. Todo mundo já sabia o que fazer. Ao final do dia a gente via os faltosos e a visitadora deveria visitá-los para verificar o porque não haviam comparecido à primeira consulta e já ficava o pedido de visita que éramos nós mesmos quem iriamos fazer. Cada visitadora tinha o seu setor e visitava somente o seu setor.

Tinha rotina para as visitas, também. $O$ arquivinho ia rodando, indicando as visitas programadas para o mês e a gente tentava atingir aquela programação. Eram cinco visitas por dia. A gente ia todos os dias. A gente tentava organizar aquela programação. Se sobrasse alguma visita para ser feita era passada para o mês seguinte.

A rotina era igual para todo mundo; todo mundo trabalhava assim." (Entrevistado $\left.n^{\circ} 19\right)$

A rigidez no cumprimento da rotina estabelecida dentro de cada programa de assistência mantinha por suporte uma exigência na forma de se relacionar hierarquicamente e entre os próprios colegas, também.

"Era regime de quartel, mesmo. Não tinha esse negócio de cada um fazer de seu jeito. Nem para os médicos, nem para ninguém. Era regime de quartel: ou você fazia assim, ou então você não trabalhava aqui.

Era rígido mesmo. Era um quartel em todos os sentidos. Era bom porque o serviço andava bem. (...) Era 'dona Fulana, dona Sicrana'. Não importava se entrava aqui com 17 anos de idade, porque na época entrava aqui com essa idade. Todo mundo se tratava por dona, senhor, senhora. Todo mundo.

Não gritava no páteo, não falava alto hora alguma. Não podia rir. (...) A chefe da enfermagem era super rígida. Nunca dava um 
sorrizinho prá gente. Ela controlava nosso horário de entrada

e saída, controlava como você estava vestida, a tua fisionomia (se estava com a cara boa ou aborrecida, doente, etc.). Se ela achasse que você estava bem para trabalhar e decentemente trajada (calça comprida ou saia; visitadora tinha uniforme para sair à rua: calça azul e camisa branca, ou saia azul abaixo do joelho e camisa branca), ela olhava tudo isso e se ela achasse que havia alguma coisa errada ela falava para a gente aguardar na outra salinha porque ela queria conversar e saber 0 que estava errado."

(Entrevistado $\left.n^{\circ} 19\right)$

O destaque ao papel das enfermeiras é enfatizado tanto em relação ao controle dos aspectos técnicos do trabalho como do comportamental, indicando que naquele momento valorizavam-se posturas mais rígidas que foram sofrendo alterações no decorrer do tempo juntamente com as transformaçōes ocorridas no perfil da população. Estas mudanças coincidem com a mudança de chefia no centro de saúde-escola. No final dos anos 70 assume o comando da unidade o professor Vranjac imprimindo uma outra prática interna nas relaçōes entre as pessoas envolvidas no trabalho. Se, por um lado, as enfermeiras centralizavam o controle de tudo que ocorria na unidade ao estabelecerem uma hierarquia direcionada aos postos de comando, por outro lado, as alteraçōes promovidas no final dos anos 70 mantinham por princípio a participação dos funcionários de forma a poder agrupar as idéias de cada um através da realização de reuniōes.

A mudança no perfil populacional exigiu mudanças internas na organização do trabalho, mesmo tendo diminuido o número de clientes da unidade com problemas sérios de saúde causados pelas insuficientes condições materiais de vida, principalmente daqueles que habitavam em favelas. As mudanças principiaram com a participação dos funcionários através da colocação de seus problemas, dúvidas, etc., nas reuniōes e não mais individualmente como era feito. Passaram, pois, a discutir os casos, o que possibilitava um conhecimento maior das doenças, em geral, e dos procedimentos a serem tomados com relação ao paciente ou aos possiveis desvios na rotina do trabalho.

É interessante o comentário de uma das auxiliares entrevistadas sobre este aspecto, enfatizando as relações internas e suas implicações com o trabalho: 
"Havia uma ética exagerada. Você não comentava, por exemplo, um problema de uma pessoa que havia sido atendida e não havia comentário algum com uma colega. Era obrigatório ler o prontuário da familia toda e se ela conseguisse ficar sabendo algo a respeito da pessoa ou família, não podia ser comentado com outro colega para que houvesse uma discussão. Agora, não. Fica-se sabendo de uma coisa que aconteceu, sabendo porque aconteceu, qual a solução dada e antes não era assim. Antes você ficava sabendo e solucionava o problema individualmente. No máximo a chefia de enfermagem ficava sabendo." (Entrevistado $\left.n^{\circ} 19\right)$

Ao mudar a forma de relacionamento, as auxiliares passaram a ter a obrigação de pensar os problemas existentes em seu trabalho. Passaram, portanto, do medo de "errar" ao ato de "pensar", procurando através destas novas orientaçōes aumentar a capacidade de cada um criar soluções para seus problemas, ao mesmo tempo que estariam contribuindo uns com os outros com novos questionamentos ou idéias que viessem enriquecer as participaçōes individuais. O medo de errar, de se expor e de não falhar, veio trazer uma série de problemas internos, já que as auxiliares haviam sido cultivadas dentro de padrōes considerados rígidos e não conseguiam compartilhar das novas idéias que foram sendo implantadas. Aos poucos foram buscando a adaptação, e essa nova forma pôde contribuir para o enriquecimento do pensamento sobre a própria dinâmica populacional: uma dinâmica acelerada, evidente dentro do serviço e que necessitava ser discutida para uma realização conseqũente do trabalho de saúde pública realizado dentro da unidade.

Toda a experiência pela qual passaram estas auxiliares mais antigas do Centro de Saúde-Escola colocava-lhes, de tempos em tempos, novos questionamentos sobre a sua prática dentro da unidade. A proximidade com a população através dos vínculos estabelecidos entre algumas delas pôde colocar em evidência não só o tempo de permanência destas funcionárias no serviço mas, também, a sua capacidade em acompanhar a evolução dos serviços oferecidos à população. Um aspecto importante a ser considerado, neste caso, é a tradição estabelecida dentro da própria unidade, desde seu princípio, de formar seus 
próprios quadros de funcionários. Ou seja, a manutenção desta forma de promover o conhecimento atualizado e aperfeiçoar seus funcionários, manteve-se presente na história desta unidade de saúde.

Dentro desse debate pode-se destacar a discussão sobre as novas demandas para as quais os serviços de saúde estão se voltando. Os anos 90 teve em seu inicio as atençōes daqueles que participaram da direção da unidade voltadas para essa questão. Alguns segmentos da população, tais como, estrangeiros (bolivianos e coreanos trabalhadores nos bairros do Bom Retiro e da Barra Funda nas confecçōes e comércio de tecidos, primordialmente); uma parcela significativa da população que passou a habitar as vias públicas da cidade, constituindo formas não comuns de agregação social (por exemplo, composição em familias não nucleares e grupos de pessoas sem laços de consangüinidade), denominadas de moradores de rua; e grupos de trabalhadoras do sexo que atuam na região central da cidade de São Paulo.

Estes novos grupos não eram, a bem da verdade, novos. Já tinham uma existência social antiga. A novidade é a de que demandaram a atenção dos serviços de saúde oferecidos pelo Centro de Saúde-Escola da Barra Funda. Atenção esta que além de despertar o interesse de muitos dos funcionários da unidade, também passou a mobilizá-los para a atuação junto a esse segmentos.

Para isso, foram necessárias a promoção de algumas rupturas com as formas anteriores de se atuar e pensar o trabalho. Por um lado, o preconceito com relação a estes grupos. Não é raro ouvir dos funcionários relatos sobre a repulsa em ter que atender, por exemplo, moradores de rua que sempre estão em condiçōes muito precárias pela falta de higiene e pelos maus tratos sofridos na vida de rua. São indicados, também, relatos da própria clientela que já freqüentava a unidade de saúde, denominados pelas auxiliares de "classes médias", que nāo suportam ter que dividir o espaço com pessoas muitas vezes com hábitos e comportamentos não condizentes com os seus, ou até casos em que o alcoolismo produz efeitos trágicos no comportamento destas pessoas.

Por outro lado, há entre os funcionários os que de fato incorporaram em sua concepção a necessidade de assistir esses grupos criados pela dinâmica social 
da exclusão econômica dentro do espaço urbano. Partem do suposto de que esta demanda não pode ser reprimida. Pelo contrário, deve-se tomar o caminho inverso e ir em busca de conhecer a realidade social que cerca a unidade de saúde e entender, inclusive os porquês da volta de antigos clientes que há tempos não freqüentavam o serviço mas que, ao perderem o poder aquisitivo, tiveram de abandonar a medicina privada na qual eram assistidos para retornar ao serviço gratuito oferecido pela unidade.

"De uns quatro anos para cá, mais ou menos, a gente percebe que muita gente que tem casa própria, que tinha convênio médico até o mês passado, escolaridade não menor do que $2^{\circ}$ grau completo, passaram a procurar os serviços de saúde oferecidos aqui."

(...) Isso despertou no serviço a necessidade de ir até estas pessoas. A gente começou a fazer trabalhos em favelas novamente. Fazer trabalho com profissionais do sexo. As prostitutas que começaram a freqũentar o serviço de uma maneira até que semelhante aos usuários normais, passaram a procurar o serviço espontaneamente ${ }^{2}$. Mas despertou na gente a necessidade de estar indo até lá, porque a população que era classe média passou a ser classe média-baixa, e quem era classe média-baixa passou a ser miserável passou a freqüentar o nosso serviço como se fôssemos pronto-socorro: sem agendamento, sem rotina, etc. " (Entrevistado $n^{\circ} 6$ )

Por fim, as questōes do ensino e da pesquisa são entendidas por estas funcionárias como aspectos fundamentais que diferenciam este Centro de Saúde de outros Centros de Saúde comuns. O ensino, o diferencia, primeiramente, por agregar alunos à prática cotidiana do trabalho. A mobilização por parte das auxiliares ocorre quando são chamadas a recebè-los e mostrar-lhes a sua rotina de trabalho. Esta requisição mobiliza o potencial explicativo de cada uma ao prepararem as suas explicaçōes sobre o trabalho, ao mesmo tempo que mobiliza-as a pensarem sua própria prática, expondo-a aos alunos de medicina e enfermagem, principalmente.

\footnotetext{
${ }^{2}$ Sobre o preconceito existente em relação às trabalhadoras do sexo, uma das entrevistadas dá a seguinte declaração: 'Você imagina que esteja gravado na testa da pessoa: 'eu trabalho com sexo'. Não é nada disso. É um pessoal comum que vem aqui." $A$ entrevistada faz muito provavelmente alusão à sua própria experiência no processo de aprender a lidar com estes novos grupos assistidos pela unidade.
} 
Para algumas, a diferença entre o Centro de Saúde-Escola e outros Centros de Saúde comuns da rede pública de serviços, decorre da constante presença de professores orientando as atividades de ensino, ou mesmo dos próprios alunos que têm contatos supervisionados com o público e que, via de regra são bem aceitos. Mas mesmo sendo uma forma de diferenciar a unidade de outras, o ensino vai no sentido dos interesses dos próprios alunos, sendo comum a idéia de que é à clientela que o Centro de Saúde-Escola deve voltar a melhor de suas atençōes. A população assistida estaria, portanto, em primeiro lugar.

A pesquisa tem seu lugar bem destacado enquanto finalidade da unidade. Já indicada anteriormente como responsável pelo conhecimento que se deve promover sobre a população para elaborar e colocar em prática novas formas de atendimento, a pesquisa também é entendida enquanto ponto de apoio promocional da unidade. Ou seja, cria visibilidade para a unidade ao apresentar seus trabalhos em encontros científicos na área de saúde. 


\section{2 - AS ENFERMEIRAS}

As três enfermeiras inseridas no Centro de Saúde-Escola Barra Funda compõem um importante referencial na organização interna dos serviços, do ensino e, também, da pesquisa. A atuação destas profissionais no cotidiano da unidade tem sua expressão maior no comando exercido perante as auxiliares no desenvolvimento dos trabalhos, fato que, por outro lado, não impede a participação das mesmas nos trabalhos de pesquisa desenvolvidos e, também, nas atividades de ensino de responsabilidade da unidade.

Um primeiro aspecto importante a ser evidenciado enquanto caracteristica destas profissionais, é o interesse pelas questões e pela prática em saúde coletiva desde os primeiros momentos da carreira profissional. Foram ouvidas as seguintes observaçōes a este respeito:

"Desde que eu comecei a pensar na formação em enfermagem eu sempre me vi dentro da saúde coletiva. Embora não tivesse claro o que era, minha formação na graduação e meu interesse sempre estiveram voltados para a saúde pública. Meus interesses, meus estágios curriculares e extra-curriculares. Sempre podia optar e sempre optei por isso. Inclusive na minha formação os estágios foram muito mais hospitalares do que qualquer outra coisa, até porque o curso de enfermagem, na ocasiāo, era um curso recente (...) daí as deficiências do ponto de vista da saúde coletiva.

(...) Nunca consegui me identificar com a área hospitalar, embora antes de me formar tenha trabalhado em hospital porque quis ter esta experiência. Mas eu sinto que a atuaçāo do profissional, do enfermeiro especificamente e do profissional em saúde coletiva, abrange uma série de coisas. Ela dá um olhar, eu diria, com maior amplitude e eu não conseguia identificar somente a doença. Tinha dificuldade em pensar a doença como doença somente, sem ver o contexto e sem entender um pouco esta dinâmica 'social-familiar' das pessoas. Então, eu sempre queria entender melhor essas coisas e eu precisava 
lançar mão de alguns recursos que eu não dispunha dentro do hospital." (Entrevistado $n^{\circ} 6$ )

Outro argumento não menos importante quanto à escolha da área de saúde coletiva, ainda baseado na distinção entre o trabalho no hospital e o trabalho voltado para ações coletivas, é a idéia de que a sistematização do trabalho em hospitais faz com as pessoas não pensem o seu próprio trabalho, promovendo uma atuação mecânica e com sentido voltado exclusivamente para a realização de tarefas (denominadas rotinas hospitalares) que estejam enquadradas na organização da instituição hospitalar.

\section{Concepções sobre saúde e organização de serviços}

A concepção de saúde coletiva destas enfermeiras fundamentase no afastamento da visão proposta pela abordagem clínica, procurando identificar a dinâmica social que movimenta não só as ocorrências de enfermidades na população, mas a necessidade de identificação dos fatores que contribuem no desenvolvimento dos processos de adoecimento. Do ponto de vista da clínica, portanto, os agravos à saúde da população não seriam solucionados, necessitando de uma abordagem que compreendesse outros elementos que contribuissem para o entendimento e para a ação em saúde.

As idéias sobre saúde coletiva explicam os porquês das escolhas feitas durante o desenvolvimento da formação e, depois, da inserção profissional no mercado de trabalho em saúde. Trabalhar no Centro de Saúde-Escola Barra Funda, portanto, é poder trabalhar "com um outro lado da saúde que não seja puramente a doença que se trabalha no hospital" (Entrevistado $n^{\circ} 7$ ). Argumento que abre, em termos práticos, a possibilidade de trabalhar, também, com outras atividades além da assistência curativa promovida em hospitais, ou do atendimento realizado pela clínica no centro de saúde-escola como, por exemplo, as atividades de 
ensino e pesquisa, os trabalhos realizados fora das dependências da unidade (visita domiciliar e assistência domiciliar) e uma prática administrativa interna diferenciada nas formas de inserção e participação das várias categorias profissionais que compõem o quadro de funcionários da unidade (neste caso, a distribuição das atribuições e dos poderes nas decisões internas).

As três enfermeiras são unânimes ao afirmarem que o trabalho no centro de saúde-escola da Barra Funda é exaustivo. É um lugar onde se trabalha mais porque o envolvimento com o trabalho é maior, tornando-se portanto mais desgastante. São muitas atividades desenvolvidas e poucas pessoas assumindo as responsabilidades (referência feita ao número reduzido de funcionários que geralmente compõem uma unidade básica de saúde).

Este "trabalhar mais" significa, em termos práticos, uma participação extensiva nas atividades desenvolvidas na unidade. Enquanto enfermeiras, a participação acaba por ocorrer em praticamente todas as atividades, o que as toma um grupo diferenciado dentro da equipe multiprofissional. Um grupo com penetraçāo em todos os espaços; com participação em praticamente todas as reuniões (seja as de atividade direta em saúde, ensino ou pesquisa, seja nas atividades administrativas) e com contatos permanentes com os profissionais da unidade. Conclui-se que estas profissionais acabam por concentrar em grau razoável de informaçōes sobre os trabalhos desenvolvidos na unidade, posicionando-se dentro dos processos internos de comunicação (formal e informal) numa perspectiva privilegiada.

Esse posicionamento difuso na hierarquia interna indica tanto uma tendência à compreensão, por parte das enfermeiras, da organização do serviço do ponto de vista da lógica da epidemiologia' que avalia a demanda, como de uma participação intensa na administração do serviço.

\footnotetext{
${ }^{1}$ A lógica da epidemiologia, neste caso, tem o significado de captar as demandas e as necessidades, identificando-as em seu perfil de morbidade e mortalidade, devolvendo ao serviço o conhecimento para a organização do mesmo.
} 
Ou seja, a lógica de avaliar a demanda (problemas existentes na área, situação de saúde da populaçāo e, consequentemente, as demandas existentes) impõe as condiçōes para se pensar e organizar o serviço. As conexōes com as questōes administrativas sāo exemplificadas com o controle necessário realizado através das fichas de notificação. Sob este aspecto, há o seguinte depoimento que vincula este problema a uma concepção de trabalho em unidade básica de saúde na implantação de um projeto sobre doenças sexualmente transmissiveis na área central da cidade:

"Estamos implantando um projeto de D.S.T. (doenças sexualmente transmissiveis) na área central que tem profissionais do sexo e população de rua. Realmente demora. Você vai identificando as coisas ao longo do tempo. Mas eu comecei a perceber esta preocupação dali para a frente. Não via isso em ninguém. Havia por parte de alguns profissionais universitários, por exemplo, uma preocupação de fazer um atendimento fantástico do ponto de vista individual. Nós temos problemas com alguns médicos aqui que ainda reproduzem o seu consultório. Em nivel individual atendem muito bem.

(...) É essa idéia de que a relação médico-paciente deve ser muito boa. Ele demora, ele conversa muito, explica muito, atende muito bem. Não discrimina. Não é um centro de saúde para pobre. Ele (o médico) dá uma boa condiçāo para a relação médico-paciente. (...) Quando lida com a questão da saúde coletiva e tem que se preocupar, por exemplo, porque as mulheres da região estão morrendo em decorrência de situações de violência, ou estão morrendo de aids e precisam fazer prevençāo às doenças sexualmente transmissiveis, eles não dão importância. Por exemplo, não preenchem uma ficha de notificação de doenças sexualmente transmissiveis porque não a consideram importante. Como se a relação médico-paciente desse conta de toda problemática social e epidemiológica. E não dá. Esse tipo de profissional é um tipo antigo que tem aqui e que reflete um pouco o que se passava de filosofia no trabalho.

Parece que as pessoas que conceberam este trabalho, 0 conceberam para que ele fosse um excelente serviço, mas com um atendimento individualizado e não tanto com a preocupação de saúde coletiva. Ou se foi, não deu 
conta de fazer com que estes clínicos se apercebessem da importància disso.

Hoje nós já temos aqui pessoas que foram contratadas com um outro perfil. Foi colocado claramente à elas que é outro perfil; a realidade é outra. Essas coisas precisam ser levadas em conta. Então a gente tem profissionais que trabalham muito bem e não só com a relação médicopaciente, porque isso tem que ser assim mesmo, mas ela não dá conta de tudo e aí a gente tem que administrar essa diferença." (Entrevistado $n^{\circ} 6$ )

\section{Inserções administrativas}

O corpo de enfermagem identifica-se, portanto, com concepções mais voltadas para a saúde coletiva ${ }^{2}$, como foi indicado até então. É um grupo novo, cuja inserção ocorre nos anos 90. Foram cultivadas sob as influências do pensamento em saúde coletiva, fato que as coloca em perspectivas diferenciadas de outros médicos que atuam na unidade ${ }^{3}$. Decorre destas diferenças um conjunto de ações que acabam por se cofigurar em conflitos no cotidiano da unidade. Por exemplo, a retirada das agendas de marcação de consultas dos consultórios médicos, as quais permaneciam sob a responsabilidade dos médicos e das auxiliares, passando-as para um controle centralizado (na central de agendamento), configurou-se como um ato administrativo que procurou dar outro encaminhamento às açōes de saúde. $O$ primeiro passo foi constatar a existência de uma demanda que se desconhecia. Uma demanda aleatória, inexplorada, desconhecida em seus aspectos epidemiológicos e, por conseguinte, em seu perfil das doenças e da mortalidade.

Assumido o controle das agendas dos consultórios médicos, 0 fluxo dos pacientes passou a obedecer uma lógica diferenciada. Ou seja, passou a existir um controle efetivo das reais necessidades demandadas na

\footnotetext{
${ }^{2}$ Não obstante, as afirmações que definem a clínica da epidemiologia enquanto "olhares" diferenciados, não separam as duas. Pelo contrário, a concepção é a de que as duas devem atuar em conjunto, complementando-se mutuamente.

${ }_{3}^{3}$ Uma das entrevistadas informa que quando de sua inserção no serviço não havia médicos sanitaristas na unidade. A base dos médicos era composta tão somente por clínicos.
} 
área de atuação a medida em que se controlava a entrada da população no serviço e não exclusivamente o trabalho dos médicos da unidade.

Dessa medida deriva uma outra afirmação: a da importância do trabalho em equipe multiprofissional. Ou seja, ao estabelecer a passagem da população por uma central de agendamento de consultas, cria-se um fluxo que permite expor a população aos cuidados, primeiramente, das auxiliares de enfermagem (supervisionadas pelas enfermeiras) que identificam a real necessidade e dão o encaminhamento, seja para os médicos, seja para outras atividades desenvolvidas como coleta de material para exames, por exemplo. $O$ envolvimento dos profissionais torna-se obrigatório a medida em que vão assumindo determinadas responsabilidades para a resolução e encaminhamento dos casos que dão entrada na unidade de saúde.

Nesse sentido, foi criado um espaço de participação maior no serviço para as categorias profissionais envolvidas. Ao assumir a responsabilidade por um encaminhamento, torna-se imprescindivel ao profissional interagir com os outros profissionais procurando cercar um campo de informaçōes e discussōes que conduzam-no à resolução do problema em questão. Um caso que entre na rotina do centro de saúdeescola acaba por ser "pulverizado" nesta sua passagem, tendo em vista que o seu encaminhamento não passa pela ação única de um médico, ou de qualquer outro profissional, mas concorre à observação e ação tanto do pessoal de nível médio como do pessoal de nivel superior. Não deixa de existir uma hierarquia das açōes identificada pelas atribuiçōes que cada carreira profissional identifica como próprias. Pelo contrário, promove-se uma participação controlada dos vários níveis de atuação no serviço procurando, por um lado, constituir uma prática de estimular os funcionários a pensarem o trabalho, e, por outro lado, executarem suas tarefas tendo por 
referência a troca de informações criadas num ambiente onde haja esta proposta. $^{4}$

As enfermeiras constituem, portanto, referencia importante em todas as atividades desenvolvidas na unidade de saúde, o que as coloca num patamar de reflexão sobre a prática do serviço diferenciada pela abrangência dos contatos realizados em todas as instâncias do serviço. $\mathrm{Na}$ prática, isto as faz refletir sobre as questões da organização do trabalho de forma a sistematizá-lo, conduzindo-o de forma a atuar consistentemente. Segundo as palavras de uma dos entrevistados:

"Onde a gente vai estar buscando uma teoria para estar entendendo esta avaliação de nossa prática? Depois, qual o objetivo que a gente está perseguindo? Os objetivos eram vários, mas eles se perdiam porque a cada momento da avaliação aparecia um objetivo novo. Aí a gente voltava para este objetivo novo que estava surgindo.

Então, quando eu falo metodologia de trabalho, estou querendo dizer sistematização para fazer a avaliação e a conclusão do trabalho porque isto é feito esporadicamente. Se a gente tivesse se organizado a gente estaria tendo isso hoje. A gente não estaria perdido. Qual o instrumento de trabalho mais concreto que a gente vai estar usando? O que a gente vai estar avaliando melhor? Qual o objetivo? Qual o tempo determinado? A gente não colocou esse prazo. Qual a meta?

(...) Quando vocè começa a escrever o que fizemos e o que vamos fazer e nas reuniōes, a gente começa a perceber que aquelas outras coisas que fizemos estão perdidas. Não criou raízes para poder caminhar sozinho." (Entrevistado $n^{\circ} 7$ )

\footnotetext{
${ }^{4}$ Sobre este aspecto, é significativo o depoimento de uma auxiliar de enfermagem presente no serviço desde o inicio dos anos 70 , já comentado anteriormente. Ela considerou que, na atualidade, as diferenças na participação no serviço do corpo de auxiliares mudou substancialmente. Passaram a exigir das mesmas que "pensassem" o seu trabalho e, para isso, seria necessário compartilhar este pensar com os colegas de trabalho ou com o diretor e com a assistente de direção da unidade, procurando conduzir as ações através de um trabalho conjunto. A informante indicou o grau de dificuldade existente para a sua participação em decorrência de sua formação e prática no trabalho anteriores: foi preparada para executar as atividades previstas pela rotina do serviço sem nunca ter sido requisitada à participação enquanto profissional que pode assumir uma autonomia maior em suas atividades de trabalho.
} 
Um outro aspecto importante nas informaçōes obtidas junto às enfermeiras é a caracterização que o serviço produz sobre a população de sua área de abrangência. Já foram indicados anteriormente algumas noções sobre o olhar epidemiológico e a sua importância na organização e direcionamento do serviço. Este seria um aspecto do planejamento do trabalho na unidade tendo em vista a necessidade de obtenção de informações que se transformem em conhecimento sobre a população. Num sentido mais amplo, outros aspectos são salientados, como indica o trecho transcrito a seguir:

\begin{abstract}
"A compreensão que a gente tem do cidadão é a de que ele está inserido num contexto mais amplo e isso deve ser discutido com os funcionários. Acho que isso a gente faz pouco. Deveriamos fazer mais. Discutir mais 0 contexto social, a realidade dele, incluindo a discussão sobre cidadania. Do direito que ele tem de interferir aqui dentro. De gerenciar, também. Acho que a gente está muito longe disso, infelizmente." (Entrevistado $n^{\circ} 6$ )
\end{abstract}

Esta expressão tem seu sentido indicado não só na perspectiva ideal, ou seja, presente em um pensamento que privilegie uma assistência médica, cuidados preventivos e promoção à saúde da população. Ela indica, também, uma disponibilidade prática em assumir determinadas ações que resultem nestes benefícios à população. A materialização, portanto, deste pensamento se configura na prática através de açōes organizadas, que vão em busca de conhecer a experiência de vida das população constatando as possibilidades de desenvolvimento de processos de adoecimento nesta, sendo as mesmas denominadas vigilância à saúde.

\title{
Vigilância à saúde
}

Estas ações promovidas pela vigilância consistem na realização de processos de observação que procuram detectar onde está inserida a população, suas condições de moradia, existência ou não de infra-estrutura 
sanitária, além de outras observações pertinentes ao entendimento das reais condiçōes de vida da população da área de abrangência da unidade de saúde. A abrangência deste conhecimento, deve cobrir toda a extensão da área de responsabilidade do centro de saúde-escola, trazendo para dentro da unidade um conhecimento que seja materializado em ações concretas de saúde. A transcrição exposta a seguir caracteriza de forma clara e sucinta o papel da vigilância, demostrando, inclusive, as questões pessoais que envolvem os funcionários nesta tarefa:

"(...) A vigilância tem um papel muito importante: buscar entender como vive esta população. As visitas são feitas para que possamos entender esta clientela; é uma visita para conhecer as novas matrículas. São pacientes novos que fazem a sua matrícula e nós vamos até seu local de moradia para fazer uma visita. Ele é avisado anteriormente e em hipótese alguma nós tentamos interferir na vida das pessoas. (...) Com a vigilância estamos tentando identificar, em termos demográficos, sociais e econômicos quem é esta população.

$\mathrm{Na}$ visita a gente está fazendo um processo de observação onde procuramos entender como vive aquela populaçāo, suas condiçōes de moradia, o que há em volta de sua moradia que possa influenciar suas condiçōes de saúde. (...) Depois dessa observação, a gente volta e faz um relatório.

Em nosso cronograma, este trabalho deverá ao final de um ano promover um levantamento dos prontuários para que possamos tentar discriminar quem é esta população. Avaliando suas condições de moradia, relacionamentos. Eu peço às auxiliares que atuam nas visitas e aos alunos (de medicina e enfermagem) que também atuam concosco, que prestem atenção nestes aspectos. Como as pessoas nos recebem, como é o relacionamento com os vizinhos: como é o relacionamento social destas pessoas que estão vindo aqui ao centro de saúde-escola. Qual o seu comportamento ao estar recebendo uma pessoa na casa dela?

Estamos tentando abranger um conhecimento razoável sobre esta população. Essa é uma outra forma de estar conhecendo. É uma população que está aderindo a uma nova proposta da gente estar conhecendo. Eles (a população) até gostam das visitas. Às vezes realmente espanta ver um monte de gente chegando de jaleco 
branco, mas elas sabem o que este monte de gente está fazendo. Somos bem cautelosos nestas intervençōes.

Fora conhecer esta população, a gente está tentando mapear onde ela está localizada, como é esta localização e essa clientela nova que tem chegado, que são os moradores de rua e os profissionais do sexo. Estas são parcelas da populaçāo que têm sacudido sentimentalmente muita gente. Eu acho que essa subjetividade deles tem nos atingido, também. É um trabalho muito difícil porque é um tipo de trabalho que cansa muito. Você está trabalhando questōes sociais muito sérias e que também estão mexendo com suas questōes pessoais. Você trabalha com moradores de rua e você saber que ela ficou na rua e que agora ela faz parte... que ela tem outras características por questōes sociais e não porque ela quis que fosse assim. Mas porque foi uma determinação social, ficou desempregado, a mulher abandonou, não teve onde se colocar e acabou ficando na rua. Ouvir as histórias das profissionais do sexo para se adequar a essa nova forma de pensamento. Não marginalizar as formas de pensamento.

Já teve dia aqui no serviço de atendermos mulheres em situaçāo de violência, queimada pelo marido e você só vai ouvir, ouvir, ouvir e não vai ter condiçōes de dar uma resposta para ela. $O$ problema dela você nāo vai resolver porque é uma decisão dela. Não é uma coisa do serviço.

Aí, à tarde chega uma criança moradora de rua e vocè não sabe o que vai fazer. Ai chega uma adolescente com suspeita de gravidez. Quando ela saiu do centro de saúde-escola estava uma chuva danada e dá uma vontade de levá-la para casa. Tem que trabalhar com isso.

(...) São essas coisas que estão chegando à nossa porta e que não chegavam antes." (Entrevistado $n^{\circ} 7$ )

Pode ser identificada, na explanação acima, uma sensibilidade maior para questões que extrapolem as finalidades de uma unidade de saúde. Uma sensibilidade que impõe um movimento de reafirmar a importância de se conhecer em detalhes e em profundidade os fatores e os problemas de saúde que atingem a população da área central da cidade de São Paulo. Propósito que coloca o processo de observação num estágio diferenciado a medida que agrega um potencial de identificar esses novos segmentos sociais que chegam com novos problemas de saúde. Ainda que 
isto não resulte em mudanças significativas nos problemas concretos que fogem ao controle das pessoas e que promovem estas questōes sociais, a organização interna do serviço demonstra, através de seu discurso e das práticas em curso, o desenvolvimento de novas idéias de como conhecer a clientela que freqüenta o centro de saúde-escola, procurando promover não só a resolução de seus problemas imediatos de saúde, mas conhecendo-a para poder aprimorar esse serviço, criando assim espaços para uma assistência que privilegie a diversidade de pensamentos e concepções. Enfim, conhecer a prática social desses grupos não inseridos nos serviços de acordo com as suas particularidades.

As visitas promovidas pelo serviço propiciam, portanto, este olhar mais abrangente e indicador não só dos problemas de saúde imediatos da populaçāo, mas cuida de observar outros aspetos também entendidos como fundamentais na composiçāo do conhecimento sobre a populaçāo. Ao sair do centro de saúde-escola, tanto os funcionários, assim como os alunos que participam das visitas, têm a oportunidade de uma aproximação instrumentalizada por um olhar centrado nas questões psíquicas e sociais. Vejamos a seguinte passagem transcrita a seguir:

"Quando a gente faz reunião de enfermagem é esta a discussão que a gente tem trazido. As perguntas não são sobre os problemas clinicos. A necessidade é a de discutir as questōes sociais e psíquicas. Isto acontece muito em função da gente ter aberto para esta nova população que passou a freqüentar o centro de saúdeescola. Está modificando a forma de pensar dos funcionários da unidade. Tanto que quando a gente começou a trabalhar estas questōes, a primeira reunião de moradores de rua foi um desastre. A gente chorava de raiva das pessoas estarem marginalizando na fala mesmo. Mas depois a gente foi analisando 0 comportamento das pessoas e percebeu que é o normal; as pessoas estavam esquematizadas para atender uma clientela que chega aqui organizada, que conhece 0 serviço e, de repente, você atende uma pessoa com um perfil completamente diferente, com uma identidade completamente perdida. 
Foi muito devagar e está sendo doloroso porque às vezes a gente entra em embate com a gente mesmo." (Entrevistado $n^{\circ} 7$ )

O reconhecimento das dificuldades enfrentadas internamente passa por uma análise, primeiramente, da organizaçāo anteriormente estabelecida dentro da unidade e o conseqũente grau de "facilidade" em manter o serviço organizado. Ao voltar sua atenção para estes grupos diferentes, não assistidos até então na normalidade da rotina do serviço, 0 abalo ocorre tanto no que diz respeito à possivel "desordem" promovida na dinâmica interna, quanto como uma "desordem ideológica" que desestrutura bases de pensamento estabelecidas desde as origens do centro de saúdeescola. Os conflitos eclodem das mais variadas formas, indo da recusa em atender a população de rua que quase sempre chega em estado de absoluta precariedade (sujos, cheirando mal, maltrapilhos, com ferimentos não tratados, desnutridos, etc.; por vezes obstaculizando o próprio atendimento ao mobilizarem os funcionários que cuidam de outras atividades) $)^{5}$, até a aceitação do fato por determinados funcionários da tentativa de viabilizar 0 atendimento e a constatação da impossibilidade de solucionar através da assistência os problemas concretos que levam estas pessoas à condiçăo em que se encontram. Novamente, a palavra de uma das entrevistadas:

"Houve resistência, sim. Ainda há. Mas é bem menor do que antes. Às vezes a gente quer cobrar das pessoas. Não que alguém esteja atendendo mal porque aqui ninguém atende mal. Mas quando atende um morador de rua, atende de forma diferenciada. Meio longe. A gente não pode estar criticando. A gente tem que estar investindo nos acontecimentos.

Houve resistência, sim, mas hoje em dia ela é bem menor. Muito menor. Porque estas coisas são trabalhadas em todas as reuniōes: saúde do adulto, enfermagem, etc. Os casos são trazidos e discutidos. 0

\footnotetext{
${ }^{5}$ Foram narrados pelo menos dois casos de pessoas que chegam e são necessários cuidados de higiene pessoal antes de serem submetidas aos cuidados das auxiliares, enfermeiras e médicos da unidade.
} 
que eu faço com um morador de rua? Ele chega com fome, roupa suja e o que a gente vai fazer? A gente discute o que fazer dentro de nossas possibilidades.

E a criança com H.I.V.? O quẽ a gente fala para a mãe? São estas as perguntas que aparecem. A pergunta não é mais quais os sintomas que aparecem numa criança com H.I.V., mas o que fazer, o que falar.

(...) As dificuldades têm sido trabalhadas no diálogo do dia-a-dia. Nas reuniōes, este complemento do dia-a-dia tem enriquecido e dado força para a gente estar trabalhando com essa população." (Entrevistado $\left.n^{\circ} 7\right)^{6}$

\section{O ensino e a pesquisa}

A participação das enfermeiras em boa parte das atividades de assistência desenvolvidas no centro de saúde-escola não as exclui da participação nas atividades de ensino e pesquisa desenvolvidas junto aos alunos que têm em seu curriculo algumas passagens pela unidade.

Esta experiência enriquece os depoimentos com considerações não desvinculadas das concepções de saúde coletiva, sociedade e mudança do perfil da população, anteriormente descritas. Num dos depoimentos surgiu a seguinte afirmação:

"Acho que o ensino aqui no centro de saúde-escola deveria ser menos voltado para questões tão especificas, especializadas, individualistas. (...) Para uma realidade tão particular como é a brasileira, complicada, um país de terceiro mundo, numa das maiores cidades do mundo, na maior do pais, acho que um ensino de mais qualidade seria aquele que contemplasse um conhecimento mais amplo dessa realidade, (...) para a partir dai ser um profissional mais adequado. Mas acho que isso está longe de acontecer." (Entrevistado $\left.n^{\circ} 6\right)$

\footnotetext{
${ }^{6}$ Foram tomados alguns procedimentos para encaminhar esta problemática intemamente, além das reuniōes onde se discutiam os vários acontecimentos. Por exemplo, foi contratada uma profissional especializada em dramatizaçōes para trabalhar os dilemas surgidos no desenvolvimento das atividades no trabalho. Também foram executadas açōes mais direcionadas ao pessoal que trabalha na recepção e agendamento e no arquivo, as quais são as primeiras a ter contato com a população de rua que entra na unidade.
} 
Ao indicar esse ideal de educação a ser transmitido aos alunos, a expressão desse pensamento atinge não uma crítica à forma como está estruturado o ensino atualmente, mas à dinâmica interna da organização que por vezes não consegue obter um desempenho satisfatório nos resultados junto aos alunos. Por exemplo, a questão da autonomia para desenvolver determinados programas de ensino dirigidos aos alunos, ou mesmo a instabilidade na direção da unidade a qual já sofreu muitas mudanças, às vezes num curto espaço de tempo.

Boa parte das considerações estão voltadas para uma análise que compreende a passagem dos alunos pela unidade como um fator importante não só aos discentes como, também, uma contribuição importante aos próprios funcionários que com eles mantêm contato. Seriam, portanto, contatos estimulantes no sentido de mobilizar as pessoas do serviço quando da demonstração e dos ensinamentos ministrados sobre o funcionamento da unidade de saúde, suas atribuiçōes perante a população local, as concepções que orientam e dão sentido à sua existência e todas as relações que ocorrem em seu meio. A frase "todo funcionário é um pouco professor" (Entrevistado $n^{\circ} 8$ ) demonstra que circula entre aqueles que atuam na unidade o pensamento de que deve haver um compromisso com o ensino, mas não somente um compromisso previsto nos pressupostos da organização.

O ensino constitui-se, portanto, em parte fundamental das atividades desenvolvidas na unidade, tendo sido incorporado ao cotidiano do trabalho, e que acaba por mobilizar os trabalhadores a pensar seu trabalho, as finalidades da organização, os problemas surgidos na rotina estabelecida para o trabalho, a suas concepções sobre a população que por lá passa e é assistida, enfim, as relaçōes estabelecidas nas situações de encontro entre alunos e profissionais da saúde que colocam estes últimos numa situação de constante reflexão sobre a sua prática. No depoimento transcrito a seguir temos uma melhor noção sobre esta situação: 
"De uma certa forma o ensino tem contribuído para a gente pensar as nossas atividades. Falo da presença dos alunos aqui na unidade. $O$ ensino estimula a gente a estar criando. É uma forma de você estar estimulando, de estar questionando suas atividades. Isso faz parte porque um aluno sempre vem com uma proposta nova e sempre consegue observar coisas que em nosso dia-a-dia a gente não consegue perceber. $E$ também a gente está tão absorvido pela dinâmica da prática e pelas relaçōes do dia-a-dia que nós não conseguimos perceber estas coisas que enriquecem em muito o trabalho.

(...) Eu vejo mais dessa forma o ensino: de estar estimulando e para repensar a nossa própria prática. É um estímulo para as auxiliares de enfermagem ao discutirem os casos com os alunos. Acho que é fundamental no processo de crescimento destas profissionais.

Ontem mesmo eu, um aluno de medicina e uma auxiliar de enfermagem atendemos a uma gestante. Eu a deixei nas mãos dos dois por um tempo. Fiquei observando e ela discutia: 'mas não é assim, é assim...'

A auxiliar de enfermagem de saúde mental faz muito isso. Ela discute muitos dos casos que atende com os residentes de psiquiatria. E ela têm muita paciência porque a gente aprende trabalhando no serviço. Dai ser muito boa essa interação entre auxiliares e alunos.

(...) Eu acho esse processo de interação um processo de crescimento e os alunos permitem muito isso. Acho que é uma contribuição mútua. Permite que a gente estude mais e busque conhecimento. Claro que a gente com a prática já busca por isto, mas acaba sendo mais intenso com os alunos aqui dentro.

Como disse um de nossos médicos: 'nós somos o espelho desses alunos; se não mostrarmos qualidade, como a gente vai cobrar qualidade?" (Entrevistado $n^{\circ} 7$ )

Por outro lado, a pesquisa tem seu papel de destaque dentro da unidade, também. Primeiro, porque cria uma certa "visibilidade externa", principalmente no que diz respeito a buscar dentro do próprio departamento de Medicina Social, ao qual está subordinado, um reconhecimento da importância das atividades desenvolvidas .

Em termos de concepção sobre o real papel do desenvolvimento de pesquisas na unidade, a concepção que prevalece é aquela que situa a 
pesquisa como fundamental no redirecionamento e conseqüente melhoria na qualidade dos serviços prestados à população. Ou seja, as açōes em saúde tornam-se mais adequadas conforme as pesquisas vão oferecendo material de reflexão.

O problema central apontado pelas enfermeiras está nas definiçōes dos temas a serem desenvolvidos nas investigações. Aqui prevalecem os interesses, por um lado, dos docentes do departamento que já trabalham determinados assuntos de investigaçāo, por outro lado, de médicos ou outros profissionais que atuam no centro de saúde-escola.

São indicadas, também, temáticas específicas de investigação, tais como, população de rua e trabalhadoras do sexo. Neste caso, as temáticas estariam sendo definidas conforme interesses individuais, ou mesmo de grupos de profissionais que cultivam interesses comuns. Os valores convergentes não são aleatórios, evidentemente. Passam por associações que, por vezes, foram construídas antes mesmo das pessoas atuarem dentro do centro de saúde-escola e significam interesses com raizes em concepções ideológicas que privilegiam problemáticas sociais não tão difundidas dentro dos serviços de saúde.

Tal afirmação apóia-se na evidência de que determinados temas de pesquisa têm sido cultivados nos últimos tempos. Se os mesmos não se configuram enquanto linhas de pesquisa estruturadas e definidas em conformidade com abordagens teóricas, esboçam, por outro lado, uma tendência em buscar conhecer grupos populacionais até então não definidos enquanto uma preocupação pertinente aos serviços de saúde. Tornar os moradores de rua, por exemplo, objeto de investigaçōes dentro de uma unidade de saúde, pode vir a contribuir para uma melhor adequação dos serviços, caso a pesquisa seja pensada somente pela sua capacidade de oferecer possibilidades de transformação. Mais do que isso, elas também podem contribuir para a melhoria do ensino oferecido aos alunos que por lá passam. 


\section{3 - AS ASSISTENTES SOCIAIS}

A atividades de assistência desenvolvidas na unidade de saúde têm sua realização integral quando compreendida em sua integração com o pessoal de serviço social no que diz respeito ao encaminhamento dos pacientes tanto na rotina interna das atividades assistenciais, quanto no acompanhamento externo da população que freqüenta a unidade.

O setor conta com a atuação de duas funcionárias com formação superior em Serviço Social e com um ponto comum na trajetória profissional: ambas passaram pela experiência de trabalhar na área de recursos humanos em unidades hospitalares de ensino, o que as coloca num patamar privilegiado de reflexão sobre a atuação em unidades básicas de saúde. Sobre este aspecto, a primeira constatação indicada nas entrevistas refere-se à dificuldade em lidar, do ponto de vista do trabalho de assistência social na área de recursos humanos, com o imediatismo das atividades hospitalares. A necessidade de sempre atuar através de soluçōes rápidas dificilmente pode ser compatibilizada com um trabalho educativo que beneficie tanto o funcionário quanto a organização como um todo.

Trouxeram desta experiência, portanto, a complexidade que tem um hospital de ensino por congregar interesses de educação, assistência e pesquisa em seu seio. $O$ conjunto de profissionais envolvidos acaba por agregar conhecimentos distintos, trabalhados de formas diferenciadas, também. Essa complexidade trouxe experiências ao mesmo tempo muito ricas e desgastantes a estas funcionárias, fato que tomou o momento de entrevista um ato de reflexão comparativa com o passado de suas trajetórias profissionais.

A passagem para 0 trabalho na unidade básica de saúde provocou nas entrevistadas um despertar para as articulaçōes internas entre trabalho e profissionais envolvidos. À dimensão reduzida da assistência realizada na unidade, quando comparada a uma unidade hospitalar, soma-se a necessidade de se compreender um objeto 
diferenciado de trabalho: o trabalho assistencial coletivo e não mais individualizado como no hospital. A unidade básica de saúde torna-se, num primeiro momento, na trajetória destas profissionais que lá atuam desde o início dos anos noventa, um espaço de aprendizagem para um novo enfoque de suas atuações enquanto assistentes sociais. $O$ enfoque voltouse para o entendimento dos problemas de saúde sob o enfoque da saúde coletiva, diluindo-se, desta forma, na diversidade esperada e encontrada na população que freqüenta a unidade de saúde.

Do ponto de vista da formação que obtiveram em serviço social, consideram que o trabalho no Centro de Saúde-Escola da Barra Funda está mais próximo daquilo que aprenderam em suas formaçōes como assistentes sociais, o que as inseriu no conhecimento sobre o que pode ser apresentado neste texto, de forma genérica, como problemas sociais existentes numa sociedade de classes.

Neste sentido, o papel das assistentes sociais no serviço projeta para fora da organização algumas de suas necessidades. Por exemplo, o vínculo com entidades assistenciais que possam promover aquilo que a unidade não tem condições de realizar, como abrigar pessoas temporariamente, ou orientar e promover ajuda para a aquisição de documentos pessoais, etc. Fruto dessa articulação entre organizações de saúde, escolas e entidades assistenciais, surge uma trama institucional cuja capacidade de resolução dos problemas da população acaba por solidificarse em ações mais concretas porque amparadas em várias formas de atividades que a beneficiam.

Mesmo com as diferenças de origem na formação e trajetória dos profissionais envolvidos no trabalho, há consenso no que diz respeito ao reconhecimento da unidade enquanto espaço apropriado ao conhecimento da realidade, tornando possivel a criação de formas de aproximação das questões sociais que praticamente não existem em outras unidades comuns dentro dos serviços públicos de saúde. A pesquisa, neste caso, estaria dando as diretrizes para a produção desse conhecimento. Mas o que torna 
esta evidência mais significativa é a sua condição de ser produzida dentro de um espaço organizacional que cultiva uma tendência a pensar na realidade à sua volta, abrindo-se a novos desafios como, por exemplo, trabalhar com segmentos populacionais até então não assistidos de forma apropriada pelos serviços, ou mesmo que tenha sido negada a inserção destes segmentos nos serviços, seja pela impossibilidade de assisti-los ou pelo desconhecimento de seus reais problemas, seja pela exclusão direta promovida pela recusa em assisti-los.

Esse valor encontrado na unidade tem sua existência explicada, por um lado, por uma organização já estabelecida internamente que estrutura formas mais apropriadas de dinamizar a produção do conhecimento ou mesmo divulgá-lo como, por exemplo, na formação de grupos de estudos sobre temas ou áreas do conhecimento especificos e produção de pesquisas; por outro lado, há, também, um envolvimento que impulsiona as pessoas a participarem destas atividades.

"(...) O que está sendo interessante para mim aqui, e isso eu nunca tinha visto, é você sair do espaço onde você está e ir em busca de realidades, conhecimentos e promover uma aproximação com a realidade que não necessariamente chega a uma unidade de saúde. É muito interessante.

Por exemplo, o trabalho que foi proposto assim que eu cheguei aqui - junto à população de rua - foi e continua sendo um desafio porque na saúde não existe nada, praticamente nada. Então, nós fizemos um processo de discussão interna e dai nasceu a idéia de se fazer um projeto para isso.

Acabamos por fazer uma pesquisa. Foi muito bom.

(...) Você tem uma realidade limite que é conseqüência de questōes estruturais, históricas e muito complicadas para se lidar. (...) Quer dizer que ao mesmo tempo que representa um desafio trabalhar com isso, por outro lado, torna-se dificil por não termos à disposição estudos na área de saúde realizados para que possamos tomar por referència." (Entrevistado $n^{\circ} 4$ ) 
O apontamento sobre o desafio que se colocam funcionários e direção da unidade representa, na perspectiva destas profissionais, um aspecto importante existente na organização que a diferencia. Esta prédisposição à elaboração de novas práticas e idéias coloca o centro de saúde-escola num plano de valorização por parte de seus funcionários confirmada pela prática do seu dia-a-dia e não somente através de discursos e projetos em andamento ou já realizados.

Esta capacidade de pensar o próprio trabalho coloca em evidência um outro aspecto fundamental no discurso e na prática destas assistentes sociais: há um sentido político expresso em suas concepções que denota a maneira como apreendem e dão significado ao seu próprio trabalho demonstrando o compromisso com o trabalho na unidade. $\mathrm{Na}$ prática do trabalho, estão presentes preocupações cujo sentido expressa tanto as questões que cercam o debate sobre as politicas públicas, assim a sua expressão material através de equipamentos públicos e privados colocados à disposição da população e, fundamentalmente, as concepções existentes internamente sobre os vários segmentos da população assistidos pelos profissionais.

O comprometimento de cada profissional pode ser identificado pela sua capacidade de produzir questionamentos. Conseqüentemente, a sua capacidade de trabalho estará se ampliando, fato que só ocorre quando os trabalhadores encontram formas de encaminhamento destes questionamentos. Colado à essa prática, encontra-se a possibilidade de que o aprendizado através do trabalho seja concretizado. A idéia de mudança nas organizaçōes traz consigo as possibilidades de inovar as idéias, transformando-as em novas práticas. Em termos concretos, o exemplo indicado faz referência principalmente às atividades desenvolvidas junto à populaçāo de rua. Sobre este segmento, vejamos as seguintes considerações transcritas a seguir:

"Há uma resistência muito grande e todo mundo passa por um processo de resistência. Eu também não gosto de 
pobreza. Seria idiotisse dizer que eu gosto de pobreza. Sou assistente social que gosta de trabalhar com a pobreza. Mas eu entendo a pobreza de outro jeito. Exatamente porque ela existe, eu não quero que ela exista. Gostaria de colaborar para um processo de mudança. Não quero ser conivente com essa coisa que cada vez cria e recria as condiçōes de pobreza.

(...) Você vê concretamente algumas coisas que impedem e emperram o trabalho. (...) A questão de tratar a populaçāo de rua de maneira repressiva, querer esconder debaixo do tapete uma realidade que é tão visivel. Limpar a cidade no sentido de tirar a população das ruas, sem oferecer nenhuma alternativa." (Entrevistado $n^{\circ} 4$ )

Dessa forma, assistir a população de rua consiste não só numa nova forma de organizar o serviço preparando-o para atendimentos fora da rotina normal estabelecida pela unidade. Consiste, isto sim, no desenvolvimento da capacidade de entendimento destes novos segmentos da população antes não assistidos. Compreender "essas novas práticas sociais", seus "significados sociais" torna-se primordial ao serviço desenvolvido numa unidade de saúde ${ }^{1}$, sem o que o serviço torna-se inviável ou circunscrito ao atendimento dos segmentos já tradicionalmente assistidos pela unidade.

A ênfase na necessidade de rever a própria rotina do trabalho coloca em questão não só a sua organização concreta e a impossibilidade administrativa de conduzir os trabalhos, mas, também, no plano das idéias e concepções dos que lá atuam, ocorrem questionamentos cuja expressão pode vir através de recusas formais em assistir determinados pacientes. Ao rever a organização do trabalho, tanto a direção quanto os próprios funcionários estariam tendo a chance de promover, através dos conflitos criados internamente, por vezes visiveis outras vezes não, um conjunto de debates que promoveriam a transformaçāo do próprio trabalho ao inserir a

\footnotetext{
1 São exemplos das noções explicativas sobre esta realidade social: o desemprego; a migração de populações de regiōes pobres para regiões com maior oferta de empregos; são pessoas empobrecidas das várias regiōes do pais e, também, da região sudeste; e, redução de remuneração com conseqüente impossibilidade de custear a moradia.
} 
possibilidade de reflexão sobre as condições nas quais estão assentadas as bases de pensamento e a ação padronizada do dia-a-dia.

Contribui para esta situação a qualidade que funda o centro de saúde: atuar como centro de ensino e pesquisa, também. $O$ conhecimento articulado entre os três pilares - assistência, ensino e pesquisa - deve garantir a qualidade da atuação da unidade e o desempenho eficiente de suas finalidades. $\mathrm{O}$ conhecimento, tanto aquele produzido pelas pesquisas desenvolvidas internamente quanto aquele que provém da escola de medicina que subordina a unidade de saúde, deve realizar a construção de um série de articulações entre funcionários e alunos, colocando à disposição daqueles que vêm para conhecer o serviço a possibilidade de observarem e atuarem em algumas atividades, concretizando a assistência com a responsabilidade de quem deve ensinar aos alunos como se faz, o que se deve fazer, quem é assistido pela unidade $e$, consequentemente, ensiná-lo sobre o papel social da unidade de saúde.

A articulação com 0 ensino torna-se fundamental em suas concepçōes, posto que não restringem a aquisição de conhecimentos adquirida pelos alunos somente às suas escolas de origem. Pelo contrário, acreditam, que a possibilidade de passar por um serviço coloca o discente em contato com uma realidade não só do profissional que atua, mas com aqueles a quem são prestados os serviços: a população, representada pelos vários segmentos sociais presentes no cotidiano do serviço.

A pesquisa sofre com a falta de conjunto de profissionais qualificados ao seu desenvolvimento. Esta é uma constatação geral encontrada entre as profissionais que lá atuam, considerando-se que a busca por informações ou mesmo formação sobre metodologia de pesquisa, procedimentos e técnicas de desenvolvimento dos projetos é uma constante. Mesmo assim, circula a idéia de que o eixo fundamental para a promoção de um movimento interno de renovação e atualização no trabalho tem sua origem na produção de conhecimento sobre a população e a própria organização do trabalho. 
É uma articulação de difícil execução já que o serviço de assistência demanda um alto número de atendimentos, o que coloca o fator tempo como impedimento à participação dos funcionários em atividades de ensino e, principalmente, nas atividades de pesquisa. 


\section{4 - OS MÉDICOS}

Foram entrevistados seis médicos pertencentes ao quadro de funcionários da unidade de saúde, sendo que três deles tiveram sua inserção nos anos 80 e os outros três nos anos 90 .

Nestas entrevistas foram incluidos profissionais que trabalham diretamente no nivel administrativo, no setor de informação, com a assistência, o ensino e, também, com pesquisas. É, como se percebe, um grupo heterogêneo porque envolvido em diferentes atividades, o que beneficiou a coleta de dados através das entrevistas, permitindo explorar uma série de perspectivas que em alguns aspectos se contrapōem e noutros se aproximam, permitindo à análise contemplar uma variedade de perspectivas sobre aquela organização.

Somente um dos entrevistados não tem nenhuma passagem pela Faculdade de Ciências Médicas da Santa Casa em sua formação na área médica. Os outros têm passagem ou pela graduação em medicina, ou pela residência, ou por ambas.

A expressão destes médicos quanto aos objetivos propostos, durante a formação em medicina, convergem para um ponto comum: a escolha em querer ajudar as pessoas promovendo um campo de relações humanas permeado por idéias salvacionistas. "É uma escolha querer ajudar os outros. Eu fui muito idealista. Acho que no fundo á uma coisa de querer ajudar as pessoas mesmo" (Entrevistado $n^{\circ} 21$ ). $O$ caráter humanitário, expresso no trecho transcrito, aponta para uma idealização do exercicio da profissão médica como possibilidade de construir uma prática que não imponha limites às possibilidades de poder ajudar as pessoas.

A transcrição apresentada a seguir demonstra claramente esta perspectiva:

"Por ser uma pessoa simples, eu sempre vi esta parte social muito clara. O emprego como clínico aqui no centro 
de saúde-escola foi oferecido quando eu estava acabando a residência. (...) Então, foi uma coisa concomitante: meu interesse pela saúde pública e o trabalho oferecido que na época já ficou em minha mente esta coisa de estar atendendo e participando do atendimento aos segmentos mais carentes da sociedade." (Entrevistado $n^{\circ} 11$ )

Apesar da idéia de que a formação em medicina possa contribuir para a ajuda dos que necessitam de cuidados à saúde, a perspectiva da saúde pública, aqui ainda entendida como atenção à saúde dos "segmentos mais carentes da sociedade", está presente na fala dos entrevistados. Há, portanto, uma conexão entre a ajuda e a realização da assistência a parcelas da população que necessitam de mais cuidados em decorrência de suas condições de vida.

Um outro aspecto que evidencia este posicionamento é a questão da formação em medicina poder contribuir com a aquisição de conhecimentos teórico-práticos que beneficiem a atuação do médico, mas que nunca podem limitar as relaçōes humanas dentro de um universo restrito pelo conhecimento. "Eu não gosto de relações humanas enclausuradas em conhecimento" (Entrevistado $\left.n^{\circ} 16\right)$, afirma um dos entrevistados indicando haver uma saida das amarras do conhecimento em busca de outras formas do pensar as questões na área da saúde.

Quanto à inserção dos entrevistados na unidade de saúde, apenas um não teve sua inserção na unidade em decorrência do desejo de querer trabalhar na área de saúde pública. Sem exceção, todos os outros foram indicados por alguém que ou trabalhava, ou já havia passado pelo centro de saúde-escola, sendo a forma de inserção realizada através de seleção pública. Boa parte das inserções ocorreram, primeiramente, através de uma aproximação via ensino, quando da realização do curso de medicina ou da residência médica, e, através das passagens obrigatórias aos estudantes pela unidade de saúde.

Estes egressos do curso de medicina vêm de uma situação comum de formação, o que não os coloca entretanto dentro de uma mesma 
perspectiva no que diz respeito aos seus interesses em trabalhar dentro de uma unidade que ofereça também a possibilidade de se trabalhar com o ensino. A oferta de emprego, interesses em trabalhar em organização que atue no ensino, a assistência aos segmentos mais carentes da sociedade, a perspectiva de que trabalhar em equipe multiprofissional amplia e areja a visão do profissional $e$ a idéia de que o trabalho em unidade básica de saúde possibilita "lidar com a não-doença" (Entrevistado $\left.n^{0} 16\right)$, o que viabiliza uma atuação em nivel promocional e não somente em termos de intervenção da assistência médica, são alguns dos motivos expostos pelos entrevistados.

O fato, portanto, de ser uma unidade que lida com ensino, acaba por provocar um estímulo aos que nela trabalham. $O$ contato com os alunos tem conseqüências importantes, tais como, a capacidade de tornar o profissional mais permeável à medida em que é questionado, o que torna o trabalho gratificante "no sentido de você passar o pouco que você tem em termos de conhecimento". (Entrevistado $n^{\circ} 21$ )

Quanto ao conceito de centro de saúde-escola esboçado pelos entrevistados, o mesmo pode ser entendido como possuindo uma abrangência razoável, não se limitando à prática da assistência médica ou às medidas preventivas, caracteristicas fundamentais de uma unidade de saúde. As considerações caminham do reconhecimento de um atendimento de qualidade a ser oferecido pelas unidades de assistência à saúde, até à prática do ensino e da pesquisa enquanto elementos diferenciadores em suas práticas profissionais.

Manter um atendimento de qualidade dentro do centro de saúdeescola significa, incialmente, poder contar com uma equipe de profissionais com muitos anos de profissão na unidade e, portanto, com uma vivência que os coloca em situação diferenciada em termos de atendimento. A seguinte passagem elucida bem a afirmação acima:

"Vem da formação interna. A maioria dos funcionários aqui têm bastante tempo de serviço e acho que uma 
cultura que tem aqui é 0 atendimento de qualidade. Vamos dizer assim: aqui o crime é você atender mal um paciente, ou cometer algum rateio técnico, porque vem aquela idéia de ensino. Aqui nós lidamos com alunos e temos que ensinar o mais corretamente possivel." (Entrevistado $n^{\circ} 5$ )

Destaca-se dentro destas afirmações a qualidade do atendimento à população como sempre sendo a forma mais correta no desenvolvimento dos trabalhos, mas somente ocorre quando embasada numa boa formação oferecida aos profissionais a qual buscaria alcançar os seguintes objetivos: boa formação técnica, visão humanitária que inclua a assistência enquanto possibilidade de relaçōes humanas não exclusivamente de trabalho e formação "ideológica" (Entrevistado $n^{\circ} 12$ ) que valorize as questōes sociais, podendo desta forma superar a visão eminentemente técnica da assistência.

De um entrevistado vem a seguinte afirmação sobre o que é trabalhar no Centro de Saúde-Escola Barra Funda:

\begin{abstract}
"Acho que, essencialmente, é você poder trabalhar com saúde. (...) E também precisa ter essa história de prevenção. Prevenção ou qualidade de vida. São duas coisas que precisam ser muito bem diferenciadas. Hoje eu trabalho aqui no centro de saúde-escola com, no mínimo, uma valorização, um contraponto quando a pessoa vem: o grau de comprometimento e de sofrimento com a opção de estar colocando à ela (paciente) o que ela tem que dispor em sua vida. (...) Então, é trabalhar com atividade, exercício físico, com capacidade elaborativa, de abstração, de fazer cursos. Eu coloco tanto em minhas condutas que é tão importante quanto saber se está tomando medicaçāo ou não. (...) É saber se ela está se empenhando na vida dela; de retomar uma vida mais saudável." (Entrevistado $\left.n^{\circ} 16\right)$
\end{abstract}

Abre-se, portanto, o caminho da intervenção técnica para outras possibilidades de captar o movimento, o processo de vida das pessoas, interferindo no mesmo, ou pelo menos sensibilizando para determinados aspectos que nem sempre são valorizados. 
O atendimento no centro de saúde-escola vai se diferenciar justamente naquilo que ele pode oferecer de melhor: mudar a concepção das pessoas de querer somente uma receita médica. Mudar a concepção "de uma população essencialmente viciada nesse tipo de serviço, principalmente serviço hospitalar e de pronto-socorro, que é a de receber receituário." (Entrevistado $n^{\circ} 16$ )

Esta mesma qualidade existente na prestação de serviços de assistência pelo centro de saúde-escola tem a sua estrutura fundada justamente em sua situação administrativa: o serviço é oferecido ao público sem nenhum ônus, ao mesmo tempo que a organização não está apensa à administração pública, criando um espaço de liberdade nas ações desenvolvidas. Sob este aspecto, o conflito emergente diz respeito à idéia que se tem, de um lado, uma visão de saúde pública que pensa e age de forma mais geral e, de outro lado, uma visão que particulariza a relação médico-paciente. A transcrição a seguir expõe em maiores detalhes esta questão:

Não há conflito, não. Eu acho legal para o profissional e para o paciente você ter esse vínculo. É bom para os dois lados porque ela (a mãe do paciente) fala: 'meu filho é paciente do dr.(a) tal', ou 'eu sou paciente do dr.(a) tal'. E mesmo a gente como profissional se sente qualificado. (...) Quando a gente fala num serviço público, a gente fala público como se nós não identificássemos ninguém que trabalhe lá. (...) Que nós tenhamos mais laços para saber da história dele (paciente) e poder acompanhá-lo de uma maneira mais adequada." (Entrevistado $n^{\circ} 21$ )

Assim, pacientes e médicos estariam unidos por laços fortalecidos porque amparados no conhecimento, ao menos parcialmente, da biografia do paciente, viabilizando proximidade através deste conhecimento. Por conseguinte, a adequação do serviço teria por suposto este tipo de atuação mais disponivel do médico. O público reconheceria, portanto, essa proximidade com o médico e manteria a regularidade nas vindas ao serviço de saúde. 
Por outro lado, uma visão de saúde pública supõe um contraponto teórico importante ao enquadrar a perspectiva anterior dentro da abordagem clínica. $\mathrm{O}$ atendimento individual não cobriria, portanto, a totalidade exigida pelo serviço, tanto em termos de conhecimento da realidade, como em função das intervençōes necessárias que a mesma requer. "A visão do clínico é muito diferente neste aspecto. Ela é muito gradual. Não é uma visāo muito clara destas diferenças (sociais). Ela vai se fazendo gradualmente." (Entrevistado $n^{\circ} 11$ )

Contraposta à noção de que a abordagem clínica isola o paciente das circunstâncias sociais que o criam, há uma outra problemática: a preocupação com a demanda que não vem ao serviço de saúde. Neste sentido, o olhar lançado pelo centro de saúde-escola à realidade que o cerca, e pela qual tornou-se responsável, deveria contemplar a amplitude e a complexidade do social, onde os vários segmentos da população diferenciam-se não só pela estratificação sócio-econômica, como também no aspecto cultural, podendo variar os hábitos, os costumes, as formas de relacionamento familiar, a atuação profissional, trabalhos alternativos ou nāo reconhecidos socialmente. Falam, portanto, da populaçāo que mora pelas ruas, dos profissionais do sexo expostos às situaçōes mais adversas, os imigrantes (bolivianos e coreanos) que chegam ao serviço trazendo o resultado da complexa trama social em que estão envolvidos, muitas vezes em situação ilegal de permanência no país.'

A discussão entre a visão da clínica e a da saúde pública impõe ao serviço a necessidade de procurar entender a complexidade social na qual o serviço está inserido e deve atuar. De um entrevistado foi dado o seguinte depoimento:

\footnotetext{
${ }^{1}$ Alguns relatos de médicos, enfermeiras, auxiliares e pessoal da administraçäo, informam que a situação de imigrantes (principalmente os bolivianos) na região central de São Paulo é precária em vários aspectos. Por exemplo, a condição da ilegalidade, situação de moradia precária (geralmente moram em porōes úmidos e alagados), familias numerasas e não restritas a um núcleo familiar, situação de trabalho complexa pois geralmente não são estabelecidos vinculos contratuais pela situação de ilegalidade, exploração econômica, péssimas condições de trabalho e os processos de adoecimento decorrentes destas situaçōes e que muitas vezes não são encaminhados aos serviços de saúde.
} 
"Eu quero que essa demanda venha e que o serviço esteja aberto, os profissionais, os recursos humanos estejam abertos com a possibilidade de estar lidando com isso. Se não sabe, reconhecer que não e dizer assim: para onde a gente vai? De que maneira a gente vai estruturar o serviço para que eles possam estar chegando? Que eles tenham direito a estar sendo atendidos aqui." (Entrevistado $\left.n^{\circ} 16\right)$

O conflito, portanto, não encerra a questão sobre a importância da atuação isolada do médico. Pelo contrário, supõe uma conexão entre o conhecimento produzido sobre a população da área de abrangência, divulgação dos serviços prestados e, principalmente, a sua incorporação ao serviço, transformando-o de idéias em práticas de saúde; materializando-o através de soluções que viabilizem uma estrutura que esteja pronta a dar respostas aos problemas de saúde da população.

Não bastaria somente estabelecer formas de conhecimento e alimentar o serviço com esse conhecimento. A área central da cidade de Sảo Paulo comporta diferenças sociais muito díspares, o que a torna uma área complexa em seu entendimento e açōes a serem promovidas. A questão é saber o que o centro de saúde-escola deveria priorizar em termos de programas que contemplassem essa complexa realidade social.

"Quando a gente começa a trabalhar com essa população da área central, a gente vai lidando com uma população que não é só moradora da área. E quando é um morador muito questionado internamente, como o morador de rua, que pula de uma rua para outra, embora permaneça na mesma região? Você trabalha com gente que passa por aqui. Estava passando, sentiu-se mal, resolveu entrar. $E$ isso é bastante freqüente por causa da avenida na qual estamos instalados. Tem bastante gente que entra porque estava passando. (...) Drogaditos, violência, mesmo as prostitutas. (...) É uma outra caracerística que é uma população que a gente sabe que existe, que a gente pouco trabalhou que é a populaçăo que está dentro dos cortiços. Acho que é um desafio para a gente estar trabalhando com esta população." (Entrevistado $n^{\circ} 5$ ) 
Este debate não se resume somente ao problema de receber a demanda espontânea. Pelo contrário, as palavras indicam a clara intenção de discutir as prioridades nas ações promovidas pelo centro de saúdeescola. Ou seja, em sua história cultivou-se a tradição de que a unidade permanecesse sempre como um laboratório onde novas formas de organização do serviço fossem experimentadas, proporcionando resultados que fossem canalizados diretamente para o ensino. Além disso, há uma clara demonstração da sensibilidade com que estas questōes sāo pensadas e encaminhadas no cotidiano do trabalho. Não se trata portanto de estabelecer grupos prioritários para o atendimento, mas viabilizar a organização do serviço direcionando-a a estes segmentos sociais, também.

A organização do trabalho, neste caso, nāo estaria restrita à programação tradicional já estruturada na rede de serviços em saúde. A mudança na prática e suas novas orientaçōes devem partir, segundo estas preocupações, de problemas a serem resolvidos, conforme explicitado no trecho transcrito a seguir:

"Tem aquela coisa de assimilar as práticas tradicionais: saúde da mulher, saúde da criança, mas no dia-a-dia a gente acaba voltando para esta questão do problema. E aí a gente pensa em formas de intervenção dentro deste diagnóstico de necessidade. Acho que a nossa tendência é esta. (...) Acho que acaba por acontecer de aparecer um problema e ter de lidar com ele. Tenho a sensação de que a prática de nosso serviço é essa." (Entrevistado $n^{\circ}$ 5)

A prática da assistência no centro de saúde-escola, portanto, volta-se para as soluçōes necessárias exigidas pelos novos problemas que vão surgindo. É evidente que, colocados no plano da espontaneidade, os problemas não chegam em sua totalidade à unidade. Pelo contrário, parte de dentro da organização um olhar que procura levantar e identificar novos problemas. 
Dentro do universo representado pela área de responsabilidade do centro de saúde-escola da Barra Funda, encontram-se moradores antigos, trabalhadores de empresas, trabalhadores do sexo (com predominância do sexo feminino), drogaditos, coreanos, bolivianos, moradores de cortiços e transeuntes adoentados. É, como se percebe, uma regiāo com uma composição social variada, apresentando problemas variados que chegam ou são trazidos para o centro de saúde-escola. Problematizar essas situaçōes torna-se o principal meio para movimentar a prática do serviço. "Para abrir as portas do centro de saúde-escola nós começamos a dar respostas que não estavam somente na assistência médica. Nós demos respostas que estavam essencialmente na mão-de-obra de nivel médio e de enfermagem" (Entrevistado $n^{\circ} 5$ )

Ou seja, deve haver, como tem ocorrido, um direcionamento interno do serviço já que uma só pessoa que chegue ao serviço pode desestruturá-lo. Portanto, a assistência médica, o pessoal de nível médio e a enfermagem passaram a ser requisitados a dar respostas a estes problemas, criando-se, por exemplo, fluxos alternativos para pacientes ocasionais, encaminhamento do paciente à auxiliar de enfermagem que tem condiçōes de identificar os sintomas e encaminhar com maior segurança e agilidade para os médicos, simplificando a assistência e criando possibilidades de melhores resultados na assistência à população.

Com relação ao ensino desenvolvido na unidade, é comum expressarem a idéia de que basicamente este tipo de atividade tem por objetivo sensibilizar os alunos de forma diferenciada. Ou seja, enfatizam a possibilidade dos alunos estarem se aproximando da realidade através da experiência de casos bem simples que ocorrem na unidade. ${ }^{2}$

\footnotetext{
${ }^{2}$ Foi citado como exemplo o caso do morador de rua que necessitou de cuidados de higiene dentro da unidade antes de ser assistido pelo médico. Discutiu-se com os alunos outras questões, além da intervenção médica no paciente, como, por exemplo, os problemas sociais que geram situaçōes deste tipo. Fundamentalmente, procura-se transmitir aos alunos a necessidade de se questionar à respeito das diferenças e das desigualdades sociais.
} 
A visão dos alunos sobre a prática médica é acrescida da possibilidade de observarem e participarem do acompanhamento de pacientes dentro da unidade, constituindo desta forma uma experiência diferenciada daquelas oferecidas pelo hospital de ensino. A contribuição da Epidemiologia vem acrescentar conhecimentos aos alunos de forma a poderem refletir, dentro de uma prática de serviço, sobre os agravos à saúde, ocorrências de enfermidades e suas conexões com as questões sociais.

A experiência de trabalho no centro de saúde-escola coloca um dilema importante, discutido por alguns dos médicos e outros profissionais da unidade, também: "todo lugar que pretende promover a produção do conhecimento, a troca - através do ensino - é muito complicada. Efervescente. Todo mundo acaba se sentindo um pouco professor" (Entrevistado $n^{\circ} 16$ ). Dilema ao mesmo tempo ameaçador e instigante, já que promove um movimento interno de renovação e atualização dos conhecimentos e das formas de transmiti-los.

Esses limites não excluem outros aspectos não menos importantes da discussão sobre o ensino na unidade. Por exemplo, a questão da quantidade de conteúdos a serem transmitidas gera, por vezes, dúvidas, assim como o estabelecimento de projetos de ensino que contemplem a discussão sobre a ética, indo além dos conhecimentos formais que podem ser transmitidos pela unidade. São questōes que contemplam, ao mesmo tempo, aspectos pedagógicos formais, assim como as questōes das concepçōes envolvidas nas atividades de ensino. Por exemplo, a formação dos médicos dentro da unidade passaria por um conhecimento sobre a prática médica voltada, num primeiro momento, para uma abordagem clínica, identificando o paciente dentro do programa específico em que está sendo atendido; posteriormente, devem ser orientados no sentido de compreenderem a inserção social do paciente, pensando as possíveis conseqüências para a sua saúde. 
No aspecto prático de sua realização, o ensino tem sua qualidade melhorada à medida em que, por um lado, a assistência está bem organizada podendo receber os alunos sem quaisquer problemas que atrapalhem o acompanhamento de consultas, visitas domiciliares ou pesquisas realizadas junto ao arquivo do centro de saúde-escola; por outro lado, é esperada uma supervisão mais extensiva por parte do departamento de Medicina Social, subsidiando mais programas de ensino na unidade.

Colada à questão do ensino vêm as consideraçōes sobre o desenvolvimento de pesquisas. Primeiramente, são apontadas a ausência de preparo de boa parte dos profissionais envolvidos nas atividades assistenciais, falta de tempo para se dedicarem às investigações e, também, a permanência de uma prática comum ao serviço de não "sistematizar as coisas; não há, por exemplo, a prática de se avaliar os serviços através de protocolos mais rigidos construidos a partir da pesquisa." (Entrevistado $n^{\circ} 5$ )

Desse ponto de vista, privilegia-se a pesquisa operacional, a qual tem sua utilidade direta na organização da prestação dos serviços à população, o que não significa que outras pesquisas não estejam ou já tenham sido desenvolvidas na unidade. Por exemplo, foi realizada uma pesquisa junto aos moradores de rua (CARNEIRO Jr. e outros, 1996) da região central da cidade com o intuito de caracterizar as necessidades de saúde da região, assim como outros trabalhos de recuperação da história da formação do centro de saúde-escola (GUIBU, 1986) observando-se a formação de alguns programas de assistência especificos e um projeto de caracterização sócio-econômica, institucional e de saúde da área sob a responsabilidade do centro de saúde-escola. (MARSIGLIA, 1995)

Por outro lado, há o que se pode considerar como uma dependência com relação ao departamento de Medicina Social no tocante às orientaçōes necessárias à execução de projetos de pesquisa na unidade. As orientaçōes consistem basicamente em discutir possiveis objetos de investigação e a pertinência que os mesmos teriam para o serviço na unidade; tomar referências metodológicas das quais poderiam ser pensadas 
formas até então desconhecidas de abordar a realidade, ou mesmo aprofundar em metodologias já conhecidas; por fim, orientaçāo no sentido de realizarem trabalhos que possam contribuir para a realização de um campo de relações mais eficientes em termos do estabelecimento de vínculos mais estáveis entre departamento e centro de saúde-escola.

A pesquisa tem seu lugar bem definido dentro das atividades desenvolvidas na unidade. Nāo que seu papel seja secundário, no sentido de vir depois, mas as atençōes estão sempre voltadas para a assistência enquanto prioridade, permanecendo o ensino e a pesquisa num plano de complementaridade, assegurando, por um lado, a permanência dos alunos e as garantias do oferecimento de um bom serviço prestado à população, por outro lado, o conhecimento gerado pelas pesquisas que alimenta e promove a reflexão interna sobre as necessidades de saúde da população ou da prática executada no serviço.

Neste sentido, ao evidenciarem a ausência de vínculos mais sólidos com o departamento, há uma clara expressão de sentirem as reais necessidades de obterem informaçōes e formação que possibilite a concretizaçāo da totalidade do trabalho realizado na unidade, unindo assistência, ensino e pesquisa num conjunto de atividades complementares. $\mathrm{Na}$ passagem transcrita a seguir as afirmaçōes expostas acima tornam-se evidentes:

"Eu espero uma orientação melhor do departamento ao qual estamos vinculados. Eu não me considero qualificado para pesquisar. Consigo ver que dentro de uma prática, pensando no perfil do serviço e lembrando o tripé ensino, pesquisa e assistência, eu acho que a minha inserção aqui começa assim: atenda bem, dê conta de sua demanda; depois você começa a fazer um trabalho de grupo com essa demanda; começa a ter uma certa penetração na equipe de trabalho na qual isto não é forçado. Isso tem que surgir naturalmente porque acredito que aqui tem pessoas qualificadas para isso.

Ai vem a questão dos alunos que em cima de uma prática, em cima do que eu faço, dá para se discutir o que se faz aqui. 
Quando eu falo pesquisa, enquanto uma coisa muito particular, um 'Olimpo' muito distante, a formação acadêmica para mim tem um nivel de exigência muito alto. Talvez por isso eu acho que seja tão dificil atingir o inatingivel.

(...) Acho que aqui - na unidade - há muito material para se pensar. Mas acho que nós ainda dependemos muito do departamento no sentido dele nortear um pouco isso. $E$ ai a gente não vai mais falar em cima de problematização. Ai tem que ser em cima de hierarquia. Eu acho que em pesquisa isso é importante: as pessoas definirem campos. Porque estamos nesses campos para pesquisar? Você conseguir se enquadrar e dizer: olha, vou por aqui, vou por ali. Delimitar um pouco. Eu imagino que não dê para pipocar projetos de pesquisas muito espontaneistas.

Há campo de pesquisa para quem quiser vir aqui e fazer, mas eu espero a tutela do departamento." (Entrevistado $\left.n^{\circ} 16\right)$

A pesquisa tem seu lugar reservado dentro do desejo de que se concretizem projetos integradores da assistência e do ensino. Alguns projetos despontaram nos últimos anos dentro do centro de saúde-escola tendo por finalidade despertar uma outra sensibilidade tanto nos funcionários, como nos alunos que por lá transitam. Ao voltarem as atenções para segmentos da população antes não enfocados pelo serviço e a pesquisa, a realização do conhecimento tem provocado conflitos cuja expressão, muitas vezes, ocorre pela dúvida em assistir determinados pacientes, como através de questionamentos que vêm contribuir para o debate interno das necessidades de transformação do próprio serviço e da orientação necessária promovida pela produção de conhecimento sobre as necessidades de saúde da população. 
Concepçoes sobre o trabalho em saúde:

\section{Estratégias no trabalho:}

Aprendizagem no trabalho:
. valorização de um trabalho de assistência fundado na ética do bom atendimento;

- realização pessoal em assistir segmentos populacionais que necessitem de cuidados à saúde em decorrência das condiçóes de vida precérias; realização individual em poder ajudar as pessoas;

- visão sobre os usuários que incorpora os vários aspectos da vida (condiçð̃es de trabalho, exclusão social, organizaçăo familiar, escolaridade, etc.); necessidade de constituir um serviço a partir da abordagem que compreenda a totalidade da vida individual e social, entendendo as doenças $\theta$ os processos de adoecimento como resultado de um conjunto de fatores de várias ordens interligados e combinados de várias formas;

- pré-disposiçăo para o aprendizado de novos conceitos e práticas que acompanhem as transformaçōes sociais; busca de novas formas de compreender e atuar junto a segmentos sociais que passaram a ser incorporados ao serviço.

- atuação que visa contemplar a proximidade com a clientela; visitas domiciliares e vínculos estabelecidos com a populaçăo;

autonomia na contratação de funcionários criando condições para a permanência e mobilidade

conflito entre categorias profissionais expresso nas demonstrações de controle da organização do trabalho e das concepç̋es;

- preservação da necessidade de formar internamente o quadro de funcionários, seja através da organização formal de cursos dentro e fora da unidade, seja através das oportunidades que surgem no dia-a-dia e que podem ser discutidas pelas equipes;

- reconhecimento de que o aprimoramento é necessário à aquisição de novas técnicas, assim como para o entendimento dos problemas sociais, das novas demandas e necessidades e a conseqüente adequação dos serviços a estas transformações. 


\section{CONSIDERAÇŌES FINAIS}

Na análise do Centro de Saúde-Escola Barra Funda foram evidenciados elementos que compõem uma caracterização geral de seu funcionamento, procurando demonstrar sua importância no conjunto da rede de serviços de saúde prestados à população da região central da cidade de São Paulo, além de suas particularidades que compõem um conjunto de relações entre grupos profissionais e população assistida pela unidade.

No plano histórico, 0 interesse durante 0 processo de investigação voltou-se para alguns eventos importantes, sendo destacados, por um lado, as transformações pelas quais os setores da administração pública estadual estava passando com a reforma promovida pela Secretaria Estadual de Saúde de São Paulo nos anos sessenta; por outro lado, as transformaçōes marcantes do ponto de vista da necessidade de se repensar as concepções e a organização dos serviços de saúde no centro de saúdeescola, promovidas a partir do deslocamento promovido pelo poder público de parcelas significativas da população que habitava em favelas na região, também foram objeto de interesse na investigação e apontados como sendo marcos significativos das transformaçōes ocorridas pela unidade de saúde em sua história.

O pleno entendimento deste processo de transformações ocorridas requer 0 entendimento de algumas consideraçōes sobre os tempos de sua formação. $O$ centro de saúde-escola foi estabelecido sobre bases muito bem definidas com relação à sua proposta de atuação, podendo ser apontada, primeiramente, a característica de ser uma unidade de saúde experimental, a qual sempre alimentou as possibilidades de repensar suas atividades. As alteraçōes no perfil da população assistida pela unidade foram contempladas, em boa parte de sua história, por um constante questionar de sua prática, colocando à disposição daqueles que por lá passam, sejam os alunos em seus estágios ou disciplinas 
obrigatórias, sejam seus funcionários, a oportunidade de uma atuação cuja dinâmica nāo despreza os acontecimentos exteriores à organização.

A qualidade de ser experimental imprimiu-lhe uma outra característica: a de pertencer e ao mesmo tempo manter a autonomia com relação à rede estatal de prestação de serviços de saúde. Se, por um lado, este fato trouxe inequivocas conseqüências positivas, como a liberdade de organizar formas alternativas de prestação de serviços à população, ou mesmo o recrutamento e treinamento de seus funcionários, por outro lado, manteve a unidade apensa a uma estrutura administrativa que distribui os recursos materiais e financeiros de forma irregular e que, em muitos momentos de sua história, deixou que o financiamento baixasse em relação aos custos dispendidos normalmente.

A autonomia trouxe conseqüências de extrema importância à execuçāo das três finalidades da organização. Por exemplo, a experiência de recrutar funcionários segundo critérios e definiçōes de perfil exigidos pela própria unidade, o que trouxe contribuiçōes à manutenção de um serviço prestado por funcionários treinados e reciclados, em boa parte dos casos, na própria unidade. Prova da importância da realização deste objetivo está na permanência, ainda nos dias de hoje, de muitos dos funcionários presentes nos tempos iniciais da unidade.

A afirmação da importância da formação do quadro de funcionários também pode ser explicada dentro da possibilidade de que valores básicos tenham sido sedimentados na unidade - "dedicaçāo", "devoção", defesa constante ao centro de saüde-escola são os mais evidentes - criando uma rede de relaçōes internas que se abastece ainda de idéias e intervençōes de professores do departamento de Medicina Social que oferece a coordenação técnica ao centro de saúde-escola, além da permanência de antigos funcionários.

À constante referência ao bom atendimento oferecido pela unidade, devem ser incorporadas tanto as aptidōes técnicas desenvolvidas e aprimoradas pelos seus funcionários, assim como as constantes 
referências da importância em assistir de forma adequada e procurar resolver os problemas de saúde dos pacientes, ou até confortá-los quando necessário. A afirmação do bem assistir encontra-se difundida enquanto orientação fundamental dentro da unidade, e incorporada a um discurso que, constantemente, a reafirma precisando a sua dimensão humanitária estão incluidos, neste caso, das auxiliares aos médicos, passando pelas enfermeiras e pelos outros funcionários de nível superior entrevistados.

As mudanças ocorridas em fins dos anos setenta, com a remoção de favelas da regiāo e a necessidade de rever os papéis desempenhados pela unidade, foi acompanhada de mudanças na forma de participação, passando a direção da unidade a valorizar a participação de seus funcionários na resolução das questões que surgiam no encaminhar das atividades. Alguns depoimentos de auxiliares que participaram do início da formação da unidade, relatam as dificuldades por elas sofridas em poder contribuir com uma participação que saisse do cumprimento das regras estabelecidas previamente pela rotina do trabalho. Não questionam em momento algum a formação técnica obtida dentro do serviço, a competência daqueles que promoveram suas formaçōes e as orientavam no trabalho $e$ nem tampouco a competència adquirida por elas mesmas nos anos de serviço, mas destacam o fator rigidez nas relaçōes hierárquicas como aspecto importante a ser considerado na análise da organização.

A valorização do trabalho tem origem nessa mesma rigidez que marcou os tempos de outrora. O senso de responsabilidade transmitido por médicos-diretores e enfermeiras, aliado à formação técnica realizada junto aos funcionários, criou raizes presentes até hoje na unidade. Importante considerar nesta afirmação que muitos egressos de graduação ou residência médica em Medicina Social na Faculdade de Ciências Médicas da Santa Casa de São Paulo permanecem atuando na unidade. Dedicação ao trabalho, devoção à prática de uma medicina voltada para a valorização da relação humanitária com o paciente, são comuns nas suas falas que evocam com uma certa freqüência uma defesa à unidade na qual trabalham. 
Esta expressão ficou evidenciada na fala dos entrevistados, nas conversas informais e mesmo nas reuniōes semestrais onde se discutia o trabalho na unidade.

Na atualidade é esperada, por parte da direção, uma participação efetiva dos funcionários nos rumos tomados pelo serviço. Esta expectativa tem relação direta com as novas perspectivas de trabalho desenvolvidas na unidade, as quais passaram a considerar a necessidade de se questionar o modelo de assistência à saúde em vigência. No caso, a organizaçāo dos serviços por programas de assistência à saúde dos adultos, mulheres e crianças.

Valoriza-se um pensamento, quase sempre colocado em prática, que privilegie um constante questionar da organização do serviço o que acarreta, consequentemente, mudanças na conduçāo do ensino e da pesquisa na unidade. A assistência passou a ser valorizada a partir da idéia de que segmentos sociais que não têm acesso ao serviço de saúde, seja por desconhecerem a oferta existente de prestação de serviços em saúde, seja por não conseguirem adentrar ao sistema de saúde que, quase sempre, não encontram o serviço preparado para recebê-los.

Quando se afirma o sentido de valorizar a atenção aos segmentos excluidos, quer se reconhecer a necessidade de mudar não só uma prática assistencial enquanto disponibilidade de recursos à serviço da população, mas uma prática que incorpore as diferenças geradas por uma sociedade cuja dinâmica de sua transformação impōe sérias modificaçōes em seu perfil de adoecimento. As necessidades de saúde da população passam a ser pensadas de forma diferenciada, incorporando-se elementos de reflexão até então não disponiveis já que, na prática, passam a ser incorporados à dinâmica do trabalho uma valorização do pensar e praticar atividades que sejam diferenciadas da prática comum da organização do trabalho.

Não basta somente assistir ao morador de rua que vai à unidade atrás de recursos e, muitas vezes, rompe com a rotina do serviço que está 
estruturada na forma de agendamento das consultas. Cria-se a necessidade de compreender sua existência social e, fundamentalmente, econômica e cultural que contribuem para essa situação, difundindo-a no serviço e incorporando-a enquanto produto de uma sociedade que promove e acirra as desigualdades materiais, políticas e simbólicas.

Pensar e praticar a assistência à saúde e as várias formas de prevenção às doenças, passa por uma reflexão sobre a própria organização dos serviços de saúde a medida em que vão sendo considerados os grupos sociais detectados no dia-a-dia e, mais do que isso, a possibilidade de tomá-los como objeto de atenção e intervenção pelo serviço, objeto de estudo para o ensino e, por fim, incorporados à prática da pesquisa que pode trazer novas contribuiçōes ao conhecimento gerado pelos que lá atuam, operacionalizando novas formas de organização do serviço, tornando-o mais eficiente $e$, fundamentalmente, promovendo uma organização que há três décadas presta serviços à população da área central da cidade de São Paulo.

Pensada no contexto das politicas públicas de saúde, o Centro de Saúde-Escola Barra Funda mantém-se enquanto uma unidade de saúde com características de uma organização de saúde pública. Isto significa afirmar sua condição de prestador de serviços públicos e, mais do que isso, responsável por uma parcela significativa da população da região central da cidade. Por outro lado, o vínculo e as diretrizes recebidas da escola médica que o subordina contribui com a relativa autonomia presente em suas açōes administrativas e do serviço. Uma autonomia que permite a revisão de sua atuação, a melhoria da capacidade de exercício do trabalho de seus funcionários e a possibilidade de uma atuação voltada à realização dos princípios doutrinários do Sistema Único de Saúde (SUS): a universalidade, a eqüidade e a integralidade. ${ }^{1}$

\footnotetext{
${ }^{1}$ Os principios doutrinários pressupōem a noção de construção de um sistema. Assim, o SUS consiste em "um sistema que significa um conjunto de unidades, de serviços e ações que interagem para um fím comum" (MINISTÉRIO DA SAÚDE, 1990: 9), promovendo a saúde, criando condições de proteger a população e, também, recuperando a saúde da população.
} 
A qualidade de ser um centro de saúde-escola cria condições de reflexão interna sobre as concepçōes de saúde e o sistema de saúde como um todo, já que em sua rotina estão presentes participantes das atividades assistenciais e de ensino. Neste sentido, a idéia de laboratório que cria as condições para o aprendizado das noçōes e da prática de saúde pública permanece válido, já que não há artificialidade na sua prática cotidiana. Pelo contrário, pertencendo à rede a sua atuação compōe-se a partir da integração com o sistema, fato confirmado pela responsabilidade assumida perante uma área da cidade com seus problemas de saúde.

Não há, portanto, uma artificialidade absoluta no que diz respeito a criar um serviço para oferecer ensino aos alunos. Pelo contrário, a unidade mantém-se presa às reais condiçōes que a realidade da qual faz parte se the apresenta. Se tomado pelo aspecto da administração financeira, a realidade é mais evidente ainda, já que a unidade sobrevive com o financiamento da Secretaria Estadual de Saúde, sofrendo as mesmas conseqüências que as outras organizações, e o sistema como um todo, sofrem.

A idéia de laboratório deve ser entendida, no caso do Centro de Saúde- Escola Barra Funda, enquanto um conjunto de práticas que sistematizem e viabilizem o ensino na unidade. Quando entendida esta afirmação, percebe-se que a assistência é colocada em primeiro lugar e dela dependem o ensino e a pesquisa.

Sob essa ótica, um outro valor pode ser realçado: o compromisso político de realizar um trabalho que atinja as finalidades da assistência, do ensino e da pesquisa, mantendo-se presente e atuante nas transformaçōes que ocorrem no sistema de saúde e este, por sua vez, incorporando as mudanças na dinâmica social. O conjunto de idéias que norteiam a atuação dos membros componentes da unidade tem por suposto um principio de atuação: realizar o trabalho contemplando as necessidades de saúde da população. Dai derivam as responsabilidades para com o ensino, atividade 
que corresponderia à realidade das condições de vida das pessoas, das famílias e dos trabalhadores da região de abrangência.

Em sua história, estas foram as prioridades assumidas e encaminhadas. Falar em valores presentes na unidade é falar dessa capacidade de uma atuação que se demonstra dinâmica e rica em contribuições aos que lá transitam seja para aprender, seja para pesquisar (e, também, aprender). 


\section{REFERÊNCIAS BIBLIOGRÁFICAS}

1) ALBUQUERQUE, J.A.G. e outros - Análise institucional de uma agência de saúde do estado na periferia de São Paulo. Mimeo., São Paulo, 1978.

2) BASSIT, A.Z.; CIAMPA, A. da C.; COSTA, M.R. - Identidade: teoria e pesquisa. Série Cadernos PUC-SP, número 20, São Paulo, EDUC Editora da Pontificia Universidade Católica da São Paulo, 1983.

3) BERGER, P. \& LUCKMANN, T. - A construção social da realidade. $14^{a}$ edição, Petrópolis, Editora Vozes, 1997.

4) BORDIEU, P. - Sistemas de ensino e sistemas de pensamento. In:

MICELI, S. (org.) Economia das trocas simbólicas. $3^{\text {a edição, São }}$ Paulo, Editora Perspectiva, 1992, p. 203-230.

5) - Campo do poder, campo intelectual e habitus de classe. In: MICELI, S. (org.) Economia das trocas simbólicas. $3^{a}$ edição, São Paulo, Editora Perspectiva, 1992, p. 183-202.

6) - Coisas ditas. São Paulo, Editora Brasiliense, 1985.

7) CARNEIRO Jr., N. e outros - População de rua: necessidades de saúde e organização dos serviços. Relatório de pesquisa apresentado à Coordenação Nacional da Rede de Investigação em Sistemas e serviços de Saúde no Cone Sul. 1996. Mimeo.

8) CENTRO DE SAÚDE-ESCOLA DA BARRA FUNDA - Projeto Especifico para 1998. Documento apresentado à Secretaria de Estado da Saúde de São Paulo, em setembro de 1997 (mimeo.).

9) CHIZZOTTI, A. - Pesquisa em ciências humanas e sociais. $2^{a}$ edição, São Paulo, Cortez Editora, 1995.

10) CYRYNO, A.de P.P. - Organização tecnológica do trabalho na reforma das práticas e dos serviços de saúde: estudo de um serviço de atenção primária à saúde. São Paulo, dissertação de mestrado, Faculdade de Medicina da Universidade de São Paulo, 1993.

11) CORRÉA, M. - As ilusões da liberdade: a escola Nina Rodrigues e a antropologia no Brasil. São Paulo, tese de doutorado, Faculdade de Filosofia Letras e Ciências Humanas da Universidade de São Paulo, 1982. 
12) COULON, A. - Etnometodologia. Petrópolis, Editora Vozes, 1995.

13) DE BRUYNE, P, HERMAN, J. \& SCHOUTHEETE, M. - Dinâmica de pesquisa em ciências sociais. $2^{\mathbf{a}}$ edição, Rio de Janeiro, Editora Francisco Alves, 1982.

14) DEMO, P. - Metodologia cientifica em ciências sociais. $3^{a}$ edição. São Paulo, Editora Atlas, 1995.

15) DONNANGELO, M.C F. \& PEREIRA, L. - Saúde e sociedade. $1^{\text {a }}$ edição, São Paulo, Editora Duas Cidades, 1976.

16) DURHAN, E. - Cultura e ideologia. In: Revista de Ciências Sociais, vol. $27, n^{\circ} 1$, Rio de Janeiro, 1984, p. 71 a 89.

17) - A pesquisa antropológica em populações urbanas: problemas e perspectivas. In: CARDOSO, R. (org.) - A aventura antropológica: teoria e pesquisa. $1^{\text {a }}$ edição, Rio de Janeiro, Editora Paz e Terra, 1986, p. 17-38.

18) ELIAS, P.E. - Estrutura e organização da atenção à saúde no Brasil. In: COHN, A \& ELIAS,P.E., Saúde no Brasil - Políticas e Organizacão de Serviços. $1^{\text {a }}$ edição, São Paulo, Cortez Editora, 1996.

19) FELDMAN-BIANCO, B. (org.) - Antropologia das sociedades contemporâneas: métodos. $1^{a}$ edição, São Paulo, Global Universitária Editora, 1987.

20) FLEURY, M.T.L. \& FISCHER, R.M. (coords.) - Cultura e poder nas organizações. $1^{\text {a }}$ edição, São Paulo, Editora Atlas, 1992.

21) FLEURY (a), M.T.L. - O desvendar da cultura de uma organização: uma discussão metodológica. In: Cultura e poder nas organizacōes, FLEURY, M.T.L. \& FISCHER, R.M. (coords.), $1^{2}$ edição, São Paulo, Editora Atlas, 1992, p. 15-23.

22) FLEURY (b), M.T.L. - O simbólico nas relações de trabalho. In: Cultura e poder nas organizacōes, FLEURY, M.T.L. \& FISCHER, R.M. (coords.), $1^{2}$ edição, São Paulo, Editora Atlas, 1992, p. 113-128.

23) F.G.V. (FUNDAÇÃO GETÚLIO VARGAS) - Dicionário de Ciências Sociais, $2^{a}$ edição, Rio de Janeiro, Editora da Fundação Getúlio Vargas, Instituto de Documentação, 1987.

24) FRANÇA, J.L. et al. - Manual para normalização de publicações técnicocientíficas. $3^{\text {a }}$ edição, Belo Horizonte, Editora U.F.M.G., 1996. 
25) FREITAS, M.E. de - Cultura organizacional: formação, tipologia, impactos. São Paulo, editora Makron Book, 1991.

26) GOFFMAN, E. - Manicômios, prisões e conventos. $4^{\text {a }}$ edição, São Paulo, Editora Perspectiva, 1992.

27) GOLDMAN, M. - Antropologia. Jornal Folha de São Paulo, 1997.

28) GRAMSCI, A. - Concepção dialética da história. $5^{a}$ edição, Rio de Janeiro, Editora Civilização Brasileira, 1984.

29) GUEDES, J. da S. e outros - Os hospitais filantrópicos e beneficentes e sua inserção nos Sistemas Unificados e Descentralizados de Saúde SUDS no Brasil. Publicado pela OPS, série de Desenvolvimento de Serviços de Saúde, n 9, Brasilia, 1988.

30) GUIBU, I.A. - Ensino médico e serviços de saúde: a experiência da Santa Casa de São Paulo. Dissertação de mestrado, Faculdade de Medicina da Universidade de São Paulo, 1986.

31) HAGUETTE, T.M.F. - Metodologias qualitativas na sociologia. $4^{a}$ edição, Petrópolis. Editora Vozes, 1995.

32) HERRERA, N.A. - Serviço social e saúde pública: instalação do Centro de Saúde Experimental da Barra Funda. São Paulo, dissertação de mestrado, Escola de Serviço Social da Pontifícia Universidade Católica de São Paulo, 1969.

33) LAKATOS, E.M. \& MARCONI, M.E.D.A. - Metodologia científica. $2^{\text {a }}$ edição, São Paulo, Editora Atlas, 1992.

34) LIMA, S.M.L. - Definição e implementação de objetivos nas organizações públicas de saúde. In: Revista de Administração Pública (RAP), Rio de Janeiro, 28(4): 38-61, out/dez de 1994.

35) LÜDKE, M. \& ANDRÉ, M.E.D.A. - Pesquisa em educação: abordagens qualitativas. $1^{\text {a }}$ edição, São Paulo, Editora Pedagógica Universitária (E.P.U), 1986.

36) MARSIGLIA, R.G. - Servidor, funcionánio, trabalhador: interesses e culturas organizacionais no setor público de saúde. Tese de doutorado, Departamento de Filosofia, Letras e Ciências Humanas da Universidade de São Paulo, 1993.

37) MARSIGLIA, R.G. (coord.) - Caracterização sócio-econômica, institucional e de saúde nas áreas da Vila Brasilândia e Barra Funda. Relatório Final do Projeto de Iniciação Científica/CNPq. Pontificia Universidade Católica de São Paulo, São Paulo, 1995. Mimeo. 
38) MARCONI, M. DE A. \& LAKATOS, E.M. - Técnicas de pesquisa. $2^{a}$ edição, São Paulo, Editora Atlas, 1990.

39) MENDES-GONÇALVES, R.B. - Tecnologia e organização social das práticas de saúde. $1^{2}$ edição, São Paulo, Editora Hucitec-Abrasco, 1994.

40) MERCADANTE, O.A. - O centro de saúde como local de estágio de saúde pública para estudantes de medicina. São Paulo, dissertação de mestrado, Faculdade de Saúde Pública da Universidade de São Paulo, 1970.

41) MERHY, E.E. - O capitalismo e a saúde pública. $2^{a}$ edição, São Paulo, Editora Papirus, 1987.

42) MICELI, S. - Introdução: a força do sentido. In: MICELI, S. - (org.), Economia das trocas simbólicas. $3^{a}$ edição, São Paulo, Editora Perspectiva, 1992, p. I-LXI.

43) MINAYO, M.C. de S. - O desafio do conhecimento: pesquisa qualitativa em saúde. $3^{a}$ edição, São Paulo - Rio de Janeiro, Hucitec-Abrasco, 1994.

44)

\& SANCHEZ, O. - Quantitativo-qualitativo: oposição ou complementaridade? In: Cadernos de Saúde Pública, Fundação Oswaldo Cruz, Escola Nacional de Saúde Pública, Rio de Janeiro, volume $9, n^{\circ} 3$, p. 239-262, 1993.

45) - O Conceito de representações sociais dentro da sociologia clássica. In: GUARESCHI, P.A. \& JOVCHELOVITCH, S. (org.), Textos em representacōes sociais, Petrópolis, Editora Vozes, 1994, p. 89-111.

46) MONTERO, P. - Reflexões sobre uma antropologia das sociedades complexas. In: Revista de Antropologia, São Paulo, USP, número 34, 1991, pp. 103-130.

47) MS (Ministério da Saúde) - Orientação para organização dos centros de saúde. In : Normas e Manuais Técnicos do MS. Brasilia, 1982.

48) MS (Ministério da Saúde - Secretaria Nacional de Assistência à Saúde/SNAS) - ABC do SUS: doutrinas e princípios. Brasília, 1990. 
49) QUEIROZ, M.I.P. de - Variaçōes sobre a técnica de gravador no registro de informaçōes vivas. Coleção Textos: $n^{\circ} 4.2^{a}$ edição, São Paulo, publicação do CERU (Centro de Estudos Rurais e Urbanos da Faculdade de Filosofia , Letras e Ciências Humanas da Universidade de São Paulo, 1983.

50) QUIVY, R. \& CAMPENHOUDT, L.V. - Manual de investigação em ciências sociais. $1^{2}$ edição, Lisboa, Editora Gradiva, 1992.

51) SÁ, E. N. de C. - Uma experiência de reforma administrativa da secretaria de estado da saúde. Dissertação de mestrado defendida na Faculdade de Saúde Pública da Universidade de São Paulo, 1978.

52) SES (Secretaria de Estado da Saúde) - Termo de convênio visando à criação, instalação e funcionamento de um Centro de Saúde Experimental. In: SIMON, U.M., O centro de saúde experimental da Barra Funda. São Paulo, dissertação de mestrado, Faculdade de Saúde Pública da Universidade de São Paulo, 1970. Anexo 1.

53) SCHEIN, E.H. - Organizational culture and leadership. San Francisco, Jossey-Bass Publishers, 1991.

54) SCHWARTZMAN, S. - A redescoberta da cultura. $1^{\text {a }}$ edição, São Paulo, Edusp, 1997.

55) SIMON, U.M. - O Centro de Saúde Experimental da Barra Funda. São Paulo, dissertação de mestrado, Faculdade de Saúde Pública da Universidade de São Paulo, 1970.

56) TRIVIÑOS, A.N. S. - Introdução à pesquisa em ciências sociais - a Pesquisa Qualitativa em Educação. $1^{\text {a }}$ edição, São Paulo, Editora Atlas, 1995. 
ANEXO 1 
data:

\section{Roteiro de Entrevista}

Apresentação:

O foco central desta entrevista são as atividades profissionais no CS-Escola.

As informações contidas nesta gravação são estritamente confidenciais e dizem respeito tão somente aos resultados que esta pesquisa pretende atingir.

\section{ROTEIRO:}

1) Formação em saúde:

. Interesse pela área.

. Especialização.

2) Atuação profissional:

. Inserção na área de saúde.

. Motivações.

3) Considerações sobre a história do Centro de Saúde-Escola:

. O trabalho no CS-Escola.

. Como é trabalhar no CS-Escola.

. Relações entre as categorias profissionais.

. Dominios internos dos espaços.

. A clientela do CS-Escola.

. Percepções sobre as mudanças sociais.

4) Ensino e pesquisa:

. Atividades relacionadas ao ensino.

. Descrição do ensino na unidade.

- Descrição da pesquisa na unidade.

. Envolvimento dos funcionários nestas atividades.

. Relações com o departamento de Medicina Preventiva e Social. 
ANEXO 2 


\section{Organograma do Centro de Saúde - Escola Barra Funda}

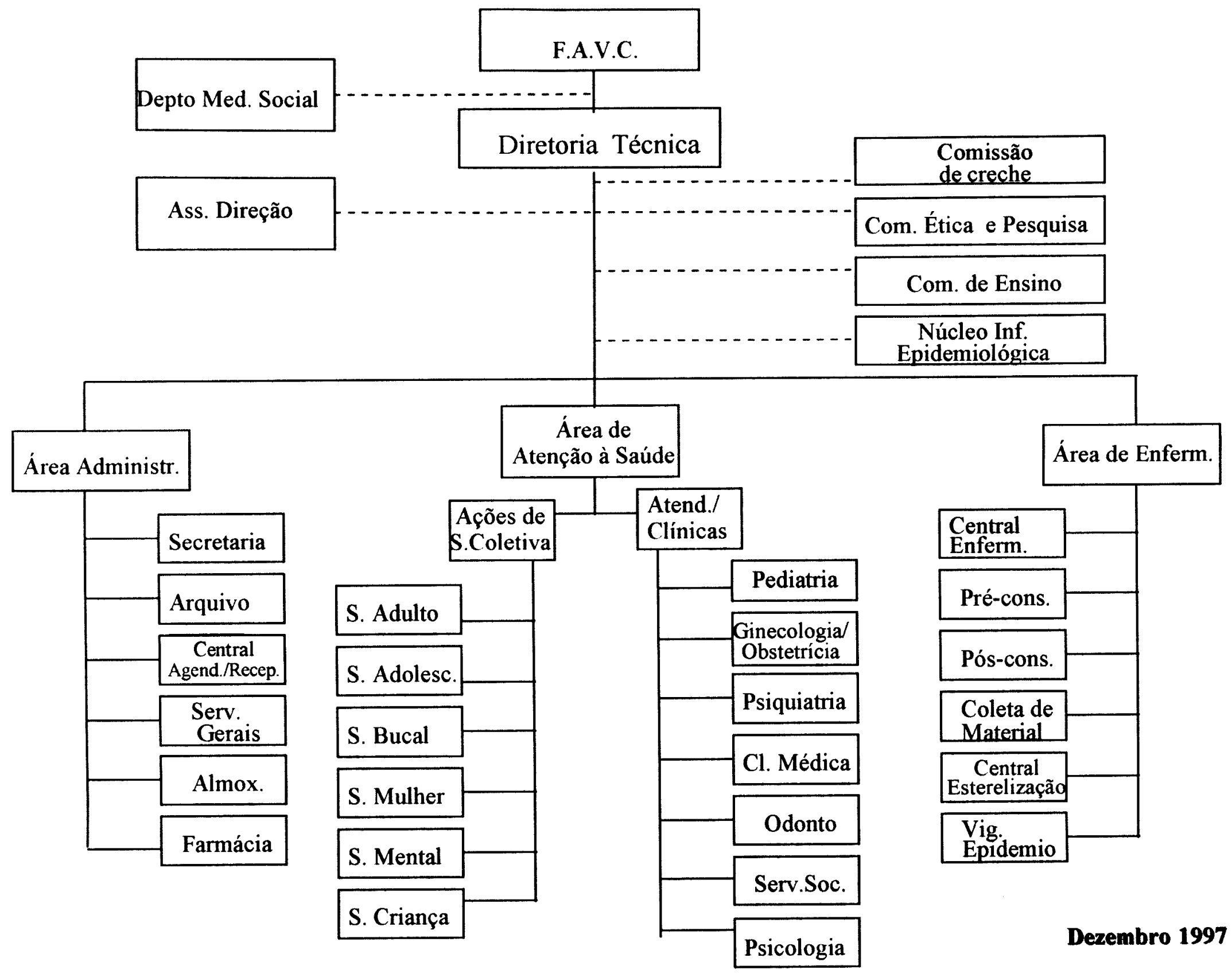

